1999

\title{
Democratic Legitimacy and the Administrative Character of Supranationalism: The Example of the European Community
}

Peter Lindseth

University of Connecticut School of Law

Follow this and additional works at: https://opencommons.uconn.edu/law_papers

\section{Recommended Citation}

Lindseth, Peter, "Democratic Legitimacy and the Administrative Character of Supranationalism: The Example of the European Community" (1999). Faculty Articles and Papers. 357.

https://opencommons.uconn.edu/law_papers/357 


\section{HEINONLINE}

Citation: 99 Colum. L. Rev. 6281999

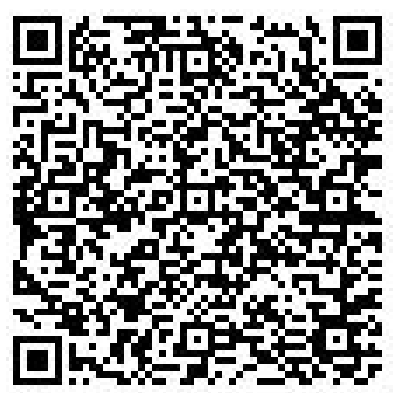

Content downloaded/printed from

HeinOnline (http://heinonline.org)

Mon Aug 15 17:08:22 2016

-- Your use of this HeinOnline PDF indicates your acceptance of HeinOnline's Terms and Conditions of the license agreement available at http://heinonline.org/HOL/License

-- The search text of this PDF is generated from uncorrected OCR text.

-- To obtain permission to use this article beyond the scope of your HeinOnline license, please use:

https://www.copyright.com/ccc/basicSearch.do?

\&operation $=$ go\&search $T y p e=0$

\&lastSearch $=$ simple\&all=on\&titleOrStdNo $=0010-1958$ 


\title{
DEMOCRATIC LEGITIMACY AND THE ADMINISTRATIVE GHARACTER OF SUPRANATIONALISM: THE EXAMPLE OF THE EUROPEAN COMMUNITY
}

\author{
Peter L. Lindseth*
}

This Article argues, from the standpoint of democratic legitimacy, that supranational institutions are best understood as administrative in character, and then explores the implications of this argument by looking at the European Community. The author concludes that the Community's "democratic deficit" flows primarily from an inability to establish democracticallylegitimate hierarchical supervision over supranational technocrats-a problem bound up with the historical relationship between demos, democracy and national political institutions as cultural symbols of popular sovereignty. The author examines aspects of Community law designed to maintain forms of national control, as well as two alternative strategies-democratization through the European Parliament, and "non-hierarchical" legitimation through transparency and participation rights in the Community regulatory process.

Finding these strategies ultimately inadequate, in themselves, to the needs of democratic legitimation, the author tums to judicial review, criti-

* Associate Director, European Legal Studies Center, and Research Scholar, Columbia Law School; B.A., J.D., Cornell University; M.A., M.Phil., Ph.D. candidate (history), Columbia University. Special thanks go to George Bermann for his unfailing support, encouragement, and insights. I am further indebted to Bruce Ackerman, Giuliano Amato, Cynthia Farina, Chris Kirkham, Jim Liebman, John Manming, Kevin Martin, Robert Paxton, Pierre Rosanvallon, Susan Rose-Ackerman, Bill Ryan, Peter Strauss, and Stephan Wernicke for providing numerous helpful comments. I presented earlier versions of this article to the law faculties at Stanford, University of Connecticut, New York University, Duke, and Yale, and I am very grateful for the many provocative questions and comments raised during those visits.

Editor's Note: To guide readers through references to the various European Community and European Union treaties, as amended, this Article uses the following abbreviations. "EC Treaty" refers to the Treaty establishing the European Community, as amended by the Treaty of Amsterdam, Oct. 2, 1997, 1997 O.J. (C 340) 1 (expected to enter into force on May 1, 1999) (for the consolidated version of the EC Treaty after entry into force of the Treaty of Amsterdam, see 1997 O.J. (C 340) 173). "TEU" refers to the Treaty on European Union, Feb. 7, 1992, 1992 O.J. 1 (C 191), [1992] 1 C.M.L.R. 573 (1992) (signed at Maastricht) (entered into force on November 1, 1993), as amended by the Treaty of Amsterdam (for a consolidated version of the TEU after entry into force of the Treaty of Amsterdam, see 1999 O.J. (C 340) 145). Unless otherwise specified, when citing to the EC Treaty and the TEU, this Article refers to the renumbered treaty provisions after the entry into force of the Treaty of Amsterdam, followed in parentheses by the former numbering. Where appropriate, this Article uses "EEC Treaty" to refer to the Treaty Establishing the European Economic Community, as amended by the Single European Act (SEA), Feb. 17, 1986 (signed at Luxembourg), Feb. 28, 1986 (signed at the Hague), 1987 O.J. (L 169) 1 (entered into force on July 1, 1987) (for a consolidated version of the EEC Treaty after the entry into force of the SEA, see Office for Official Publications of the European Communities, Treaties Establishing the European Communities 207 (1987)). The "Treaty of Rome" refers to the original Treaty establishing the European Economic Community, Mar. 25, 1957, 298 U.N.T.S. 11 (1958) (sigued at Rome). 
cally analyzing the deference shown by the European Court of Justice to Community legislative decisions relative to the more democratically-legitimate Member States. Finding this broad deference inconsistent with the Community's administrative character, the author outlines an alternative approach-a substantive presumption against supranational legislative autonomy-as well as a new procedure-a "European Conflicts Tribunal"to resolve conflicts over the scope of the relative legislative authority of the Member States and the Community. The purpose of these reforms would be to mediate between the legitimate needs of legislative harmonization at the Community level, on the one hand, and the persistence of the nation-state as the historically legitimate symbol of democratic sovereignty, on the other-a tension that arguably exists in any supranational body.

\section{TABLE of Contents}

1ntroduction: A New Dimension To An Old Problem ........ 630

A. The "Democratic Deficit" - National and Supranational .. 633

B. The Example of the European Community .............. 635

C. The American Perspective ....................... 642

1. Supranational Delegation and Democratic Legttimacy: General Consmerations .......................... 645

A. Legitimacy in National Administrative Institutions ....... 645

B. Legitimacy in Supranational Institutions .............. 648

II. The Administrative Character of Supranationalism in THE EuROPEAN CoMMUNITY ........................

A. Institutional Background: The European Community and the European Union Distinguished....................

B. The Limitations of the Existing Descriptive Categories: The Community as International Organization and as Constitutional Polity ............................ 654

C. An Alternative Analytical Framework: The Community as Supranational Administrative Agency .................

III. Supranational Legislation and Legttimate Political Control ....................................

A. Legislative Blockage in the Community and Integration by Adjudication ....................................

B. The Advent of Autonomous Lawmaking at the Community Level ......................................... 665

C. Defining the Sphere of Continuing National Control ....... 668 1. Subsidiarity ................................. 668

2. The Pillar Structure....................... 669

3. "Variable Geometry" and "Closer Cooperation"........ 670

D. The Likelihood of Intensified Disputes over the Relative Legislative Competences of the Community and the Member States .................................... 672

IV. Supranational Democratization Versus Democratic LegrTmacy ..................................... 672

A. Overcoming the "Democratic Deficit": The Parliamentary Democratization Strategy .......................... 
B. The European Parliament and the "No Demos Thesis" .... 675

C. The "Hard" and "Soft" Versions.................... 677

D. The Continued Pull of the Nation State .............. 680

V. Participation, Transparency, and the IDEal of a

Deliberative Supranational Teghnocracy ............ 683

A. Technocracy and the "Pathologies" of Democratic Politics ... 683

B. "Depoliticization" and the Cultural Foundations of

Technocratic Autonomy......................... 686

C. Supranational Technocratic Autonomy and National Control: The Imperfections of the Comitology System ............. 689

D. "Deliberative Supranationalism"................... 691

E. The Normative Yearning for Legitimate Political Control: Lessons from the American Experience ................ 693

VI. Democratic Legitimacy and Treaty InTERPRETATION ..... 699

A. A Presumption against Supranational Normative Autonomy ................................... 699

B. Teleological Interpretation and the Constitutionalist "Preference for Europe" ........................... 701

1. Direct Effect and l'effet utile .................. 701

2. Supremacy ............................ 703

3. Community Competence and Internal Institutional Balance.................................... 704

a. Implied Powers......................... 704

b. Legal Basis .......................... 705

4. The Court's Problematic Pursuit of Democratic Values. . 706

5. Signs of Restraint After 1992................... 710

C. The Persistence of the "Preference for Europe" in the Emerging

Case Law on Subsidiarity........................ 712

1. Preliminary Considerations: Comparing the Deference Owed a Constitutional Legislature and an Administrative Agency....................... 713

2. Deference to Conclusory Findings of the Community "Legislature" on Questions of Subsidiarity ........... 714

3. The Rejection of Subsidiarity as an Interpretive Principle................................. 718

D. Choice of Legal Basis and Subsidiarity as a Nondelegation Doctrine ..................................... 723

VII. The ISSUE OF KOMPETENZ-KOMPETENZ TOWARD A European Conflicts Trubunal ..................... 726

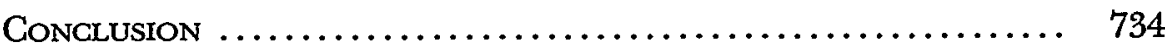

\section{Introduction: A New Dimension to an Old Problem}

Ensuring democratic control over delegated normative power has been a major constitutional challenge in the twentieth-century adminis- 
trative state. ${ }^{1}$ As the century draws to a close, however, this challenge is taking on a whole new dimension, one intimately related to the changing nature of the nation-state as a locus of sovereignty and governance in a globalizing economy. ${ }^{2}$ In varying degrees, we are witnessing delegations of normative power to institutions operating outside the confines of the nation-state, generally under the auspices of trade agreements and the institutional mechanisms that they create. The identifying characteristic of the emerging legal order is the formal role given to non-national decisionmakers in the elaboration and/or control of regulatory norms that apply within national borders.

From the national standpoint, these decisionmakers often enjoy a significant degree of legal autonomy, in that no particular state is guaranteed a formal veto over their supranational policy choices. ${ }^{3}$ In its most rudimentary form, this autonomous "supranational normative power" tends to be adjudicative, as under the dispute settlement mechanism of the World Trade Organization (WTO). ${ }^{4}$ In its more advanced form, as under the European Community, ${ }^{5}$ it can also be specifically and quite extensively legislative in nature, relying on supranational institutions to

1. The term "delegated normative power" is used here in both a legislative and an adjudicative sense, encompassing the authority of administrative bodies to make rules of general application (quasi-legislative power) as well as the power to elaborate the meaning of legislative provisions on a case-by-case basis through administrative adjudication. For a discussion of the legal and political mechanisms that have developed to control delegated normative power at the national level, see infra notes 66-76 and accompanying text.

2. See generally Neil MacCormick, Beyond the Sovereign State, 56 Modern L. Rev. I (1993) [hereinafter MacCormick, Sovereign State]; Neil MacCormick, Sovereignty, Democracy and Subsidiarity, in Democracy and Constitutional Culture in the Union of Europe 95 (R. Bellamy et al. eds., 1995) [hereinafter MacCormick, Sovereignty, Dennocracy and Subsidiarity].

3. Whether this formal-legal autonony results in actual autonomy for supranational decisionmakers is extremely difficult to measure and thus subject to debate among social scientists. See, e.g., Mark A. Pollack, Delegation, Agency, and Agenda Setting in the European Counmunity, 51 Int'l Org. 99, 110 (1997); see also infra notes 288-294 and accompanying text.

4. The new dispute settlement procedures should play a critical role in elaborating the content of otherwise vague treaty norms, almost certainly in ways not entirely expected by the original signatories. Given this delegated normative power, it is perhaps not surprising that legal scholars are beginning to examine the WTO's dispute settlement procedures in administrative law terms. See, e.g., Steven P. Croley \& John H. Jackson, WTO Dispute Procedures, Standard of Review, and Deference to National Governments, 90 Am. J. Int'l L. I93 (1996); Philip M. Nichols, Extension of Standing in World Trade Organization Disputes to Nongovernment Parties, 17 U. Pa. J. Int'l Econ. L. 295 (1996); Kim Rubenstein \& Jenny Schultz, Bringing Law and Order to International Trade: Administrative Law Principles and the GATT/WTO, 11 St. John's J. Legal Comment. 271 (I996).

5. The focus of this article is on the institutions of the European Community, not those of the European Union. Only the institutions of the EC are truly "supranational" in character, whereas those of the Union remain intergovernmental. The relevance of the EC/EU distinction is explamed in greater detail below. See infra notes 91-93 and accompanying text. 
make rules of general application. In both instances, nation-states have relinquished a measure of control over the content of regulatory norms in the interest of more efficient and coherent international cooperation and coordination.

This Article views supranational delegation as the next stage in a process of diffusion and fragmentation of normative power that has dramatically altered the balance of power at the national level over the course of the twentieth century. Central to this process has been a shift in normative power out of the legislative realm into an increasingly complex and variegated administrative sphere, one which now extends to the supranational level. Nationally, this shift has involved three interrelated institutional elements: first, the assertion of executive predominance within the state, deemed necessary to assure rational internal management as well as the projection of national political and economic power on an international level; second, the political and institutional triumph within the executive of the technocrat, for whom a "depoliticized" expertise and a respect for the tenets of administrative legality (subject to some form of judicial review) have served as the primary bases of legitimacy; and third, the widespread use of enabling legislation, which, rather than specifying regulatory norms directly, delegates this authority to an administrative agency. ${ }^{6}$

These institutional elements are also manifest in the phenomenon of supranational delegation, albeit in somewhat modified form. National executives and bureaucracies continue to play the central role in defining national policy interests and in defending them in supranational institutions, but now the purpose is "to lift the management of the market to a more effective systemic level. ${ }^{\text { } 7 ~ E n a b l i n g ~ l e g i s l a t i o n ~ t a k e s ~ o n ~ a ~ n e w ~}$ guise-a treaty or other international agreement transferring normative power to non-national technocratic agencies--but now the aim is "to address problems beyond the effective political control of even the largest

6. For a theoretical discussion of the changing nature of legislation in the modern administrative state, see Edward L. Rubin, Law and Legislation in the Administrative State, 89 Colum. L. Rev. 369, 380-85 (1989) (describing "transitive" versus "intransitive" legislation).

7. Wolf Sauter, The Economic Constitution of the European Union, 4 Colum. J. Eur. L. 27, 66 (1998) (citing Andrew Moravcsik, Preferences and Power in the European Community: A Liberal Intergovernmentalist Approach, $31 \mathrm{~J}$. Common Mkt. Studies 473 (1993); Alan S. Milward, The European Rescue of the Nation State (1992)). 
individual states." 8 National legislatures play, at best, a decidedly secondary role in the process of supranational policymaking. ${ }^{9}$

\section{A. The "Democratic Deficit" - National and Supranational}

As with delegation to national administrative institutions, the phenomenon of supranational delegation-particularly that of legislative power-raises important questions of democratic legitimacy that this Article explores. ${ }^{10}$ There is, one might say, a basic "democratic deficit" (to use a phrase that has gained wide currency in Europe) common to both forms of delegation. Each involves the transfer of normative power to agents that are not electorally responsible in any direct sense to the "people" whose "sovereignty," or at least some portion of it, the agents are said to exercise. ${ }^{11}$ On the national level, administrative agencies are responsible politically, not to the people directly, but to their representative institutions (executive and legislative), which are the privileged means by which the democratic preferences of the national community are trans-

8. Sauter, supra note 7, at 66; see also Inger-Johanne Sand, Understanding the New Forms of Governance: Mutually Interdependent, Reflexive, Destabilised and Competing Institutions, 4 Eur. L.J. 271, $286 \&$ n.32 (1998). The purpose of the present article is not to identify the causal factors driving delegation but rather to examine how delegationnotably supranational delegation - can be reconciled with democratic principles. There is a large literature, especially in the United States, that seeks to explain why delegation occurs or how regulatory norms are ultimately shaped. For a detailed examination, see Steven P. Croley, Theories of Regulation: Incorporating the Administrative Process, 98 Colum. L. Rev. 1 (1998). For a discussion of theories of regulation as they relate to Europe, see Michelle Egan \& Dieter Wolf, Regulation and Comitology: The EC Committee System in Regulatory Perspective, 4 Colum. J. Eur. L. 499 (1998).

9. This phenomenon is especially pronounced in the EC/EU. See Deirdre M. Curtin, Postnational Democracy: The European Union in Search of a Political Philosophy 48 (1997) [hereinafter Curtin, Postnational Democracy] ("[T]he process of closer European integration ... has had the effect of fragmenting and dispersing the legislative power of the individual constituent nation-states. At the same time the excessive empowerment of the executive results in a neo absolutist process of decision-making with dramatic consequences for notions of democracy enshrined at the national level.").

10. Part I, infra, provides a general overview of the criteria of democratic legitimacy used in this article.

11. The quotation marks signify that terms like "people" or "sovereignty" (or, for that unatter, "nation" or "deunocracy") are analytical constructs that can be descriptively problematic, and they should therefore not be endowed with any inherent meaning apart from historical and cultural context. They belong to a cultural system of interpretation built up over time which both shapes popular perceptions of events and the changing structures of material life-institutional, economic, and social-and controls the meaning that individuals give to social and political action affecting the stability of the governing regime. The cultural system of interpretation also evolves historically-that is, its underlying notions become imbued with new meaning-in response to those same events, structural changes, and actions. See generally Marshall Sahlins, Islands of History (1985). From this perspective, the question of democratic legitimacy is not political-theoretical but historical and cultural: The popular acceptance of a particular regime is rooted in its perceived linkage to the "people," however that term is defined in a given time and place. On the formal-institutional structures that have developed historically to establish that linkage, see infra Part I.A. 
lated into general legal terms. Institutions exercising supranational normative power, however, exist in an even more attenuated "two step" relationship with the people, or rather the "peoples" of the various participating states. ${ }^{12}$ Because supranational bodies lack the requisite direct connection to the perceived source of sovereign power upon which democratic legitimacy is based, this Article views them as essentially administrative in character.

Viewed from an administrative perspective, how might the normative output of these emergent supranational bodies be legitimized in democratic terms? There is a tendency among those who stress the benefits of delegation and the virtues of administrative governance (whether nationally or supranationally) to measure legitimacy in terms of expertise and efficient policy outcomes, with some form of legal control-judicial review-serving as perhaps the only effective means of checking the exercise of administrative rulemaking. ${ }^{13}$ If this were so, then technocratic assertions of efficiency and expertise, along with the observance of some form of supranational "legality," might be adequate, in themselves, to legitimize the normative output of supranational administrative bodies. ${ }^{14}$ National experiences with the development of the administrative state, however, strongly suggest that this route to democratic legitimation is inadequate in itself. In most states, forms of participation and transparency rights are developing in some degree as a further check on administrative power and as a complement to legal control; indeed, these rights may point to the emergence of new forms of "democratic" representation in the modern administrative state. ${ }^{15}$ More importantly, however, even as transparency and participation rights have taken on an increasingly important legitimating function, traditional forms of hierarchical supervision by elected representatives (both executive and legislative) have remained of paramount importance, providing the essential legitimating mechanism for the exercise of delegated normative power within the administrative sphere. ${ }^{16}$

This persistent need for democratically legitimate, hierarchical-political oversight and control over administrative decision makers points to perhaps the most problematic aspect of supranational delegation. By definition, in a supranational body there is no democratically-legitimate hier-

12. The notion of a "two-step" relationship is taken from Richard J. Pierce, Jr., The Role of the Judiciary in Implementing an Agency Theory of Government, 64 N.Y.U. L. Rev. 1239, I240 (1989).

13. See generally infra Part V.A; infra notes $295-299$ and accompanying text.

14. One commentator has gone so far as to express the view that "[e]fficiency may even substitute democracy as a source of legitimation or as a legitimating argument." Markus Jachtenfuchs, Theoretical Perspectives on European Governance, 1 Eur. L.J. I15, 129 (1995).

15. See infra text accompanying notes 70-71.

16. See infra text accompanying notes $73-76$. 
archical superior, as we understand that notion in a national sense. ${ }^{17}$ Rather, there are at best indirect political controls exercised by national executives over otherwise-autonomous supranational, technocratic agents who owe their loyalty to the membership of the supranational body as $a$ whole rather than to any one particular state. Although the pursuit of efficient international cooperation may demand a shift in the locus of regulation to reasonably autonomous supranational institutions, popular notions of legitimation and control have remained wedded to the hierarchical political institutions (executive and legislative) of the "sovereign" nation-state. ${ }^{18}$ In short, the evolving forms of supranational policymaking are out-pacing our traditional, state-based conceptions of how delegated normative power should be democratically controlled.

\section{B. The Example of the European Community}

This Article explores this problem of legitimation and control in supranational bodies by looking at the experience of the European Community. ${ }^{19}$ The Community example is telling, I argue, because it is perhaps the most advanced model of supranationalism that we know, exercising not only adjudicative but also executive and legislative functions as well. Although purportedly an entity possessing only enumerated powers, the scope of the Community's normative authority has steadily increased since its inception in the I950s, partly due to explicit transfers from the Member States, but more importantly due to an expansive interpretation of Community competences by the Community institutions themselves, notably the European Court of Justice (ECJ). ${ }^{20}$ Because of the dramatic expansion in normative power at the supranational level in Europe over the last forty years, it was not uncommon to see the Euro-

17. Emblematic of the problem is the recent body of literature in the social sciences that examines the problems and prospects of "Governance without Government." See Jachtenfuchs, supra note 14, at 121 (citing, e.g., Governance without Government: Order and Change in World Politics (James Rosenau \& Ernst-Otto Czempiel eds., 1992)); see also Sand, supra note 8; Antje Wiener, The Embedded Acquis Communautaire: Transmission Belt and Prism of New Governance, 4 Eur. L.J. 294 (1998). On the increasing recourse to the notion of "governance" in the social science literature to describe the EC/EU phenomenon, see Kenneth A. Armstrong, Legal Integration: Theorizing the Legal Dimension of European Integration, $36 \mathrm{~J}$. Common Mkt. Studies 153, 168 (1998).

18. Sol Picciotto, Networks in International Economic Integration: Fragmented States and the Dilemmas of Neo-Liberalism, 17 Nw. J. Int'l L. \& Bus. 1014, 1055 (1997) [hereinafter Picciotto, Networks]; see also Sand, supra note 8, at 289.

19. I use the term "European Community" to encompass the three separate European communities founded in the 1950s: the European Coal and Steel Community (ECSC), founded in 1951; the European Community (formerly the European Economic Community, or EEC), founded in 1957; and the European Atomic Energy Community (Euratom), also founded in 1957. Since the 1960s, the three communities have shared institutions (Council, Commission, Parliament, and the Court of Justice), and, for the sake of simplicity, I refer to them simply as the EC. Together, the three European communities constitute the "first pillar" of the European Union. For further institutional background on the EC and the EU, see infra notes 91-93 and accompanying text.

20. See generally infra Part VI.B-C. 
pean Community (and now the European Union ${ }^{21}$ ) described as something more than a mere international organization of otherwise independent sovereign states. Rather, it has often been argued that the Community has taken on the character of a constitutional polity in its own right-a self-legitimating, autonomous level of governance in a federal-type system-characterized by "a high degree of pooling of sovereignty, and important roles given to centralized institutions."22

This Article adds to an already extensive body of scholarly literature critical of this "constitutionalist" characterization of the European Community. ${ }^{23}$ In important respects, it challenges, as others have, the "venerable federalist vision" of an ever-expanding, supranational, institutional order, characterized by an autonomous legislative process that is uniform and undifferentiated across all issue areas as in a constitutional polity. ${ }^{24}$ However, in making this argument, I also hope to develop further an alternative perspective on the legal nature of Community institutions and of supranationalism more generally, one drawn from principles of administrative law. ${ }^{25}$ The constitutional character of Europe's supranational institutions cannot simply be inferred from their undisputedly broad range of delegated sovereign powers: Administrative bodies, by definition, also exercise delegated sovereign powers, although their source is not constitutional but rather simply legislative, and their legitimacy is rooted not in direct democratic control (i.e., elections) but in other forms of political and legal supervision..$^{26}$ Despite much of the constitutionalist vocabulary used to describe the Community - by lawyers and judges especially ${ }^{27}$ the EC is not unlike any other supranational body exercising delegated normative power in that, from the standpoint of democratic legitimacy, it is fundamentally of an administrative character. The Community draws its authority not from a constitutional enactment of some definable Euro-

21. On the institutional distinction between the EC and the EU, see infra notes $91-93$ and accoinpanying text.

22. Introduction, International Regulatory Competition and Coordination: Perspectives on Economic Regulation in Europe and the United States 29 (Bratton et al. eds., 1996) [hereinafter International Regulatory Coinpetition and Coordination]; see also infra notes 102-105 and accompanying text.

23. See infra notes 106-109 and accompanying text. For an overview, see J.H.H. Weiler \& Joel P. Trachtman, European Constitutionalisin and Its Discontents, 17 Nw. J. Int'l L. \& Bus. 354 (1996-1997).

24. Andrew Moravcsik \& Kalypso Nicolaidis, Keynote Article: Federalist Ideals and Constitutional Realities in the Treaty of Amsterdam, 36 [Annual Review] J. Common Mkt. Studies 13, 16 (1998) (arguing that “[t] he teleological ideal-a 'United States of Europe' characterized by centralized, uniform, universal and undifferentiated institutions-is no longer an appropriate standard (if it ever was one) by which to judge further steps toward integration").

25. For a more detailed elaboration of the analytical framework drawn from administrative law as it specifically relates to the EC/EU, see infra Part II.C (referring also to commentators who have advanced similar views).

26. See infra notes $63-76$ and accompanying text.

27. On the advent of the constitutionalist interpretation, particularly among lawyers and judges, see generally Weiler \& Trachtman, supra note 23. 
pean "demos," or people-the prerequisite of democratic legitimacy 28 but generally from lawful transfers of normative power from national parliaments as representatives of their respective national communities. ${ }^{29}$ Like an administrative body, the key sources of legitimacy in the Community are found in political and legal, and not directly democratic, control mechanisms. ${ }^{30}$ From this perspective, Community institutions operate as a multi-function agency-a category Americans know well-with executive, legislative, and adjudicative jurisdiction stretching across vast areas of economic and social regulation, unique in that it takes its mandate from multiple political principals, i.e., the Member States and their electorates. ${ }^{31}$

28. The relationship between dennos and dennocratic legitimacy is explored in greater detail infra Part IV, which discusses extensively the thesis advanced by Joseph Weiler, Does Europe Need a Constitution? Deinos, Telos and the German Maastricht Decision, 1 Eur. L.J. 219 (1995) [hereinafter Weiler, Demos].

29. It is of course true that Community institutions have also benefitted from several transfers of normative power directly from the "peoples" of certain Member States, via popular referenda revising their respective constitutions (particularly following the Treaty of European Union of 1992). For an overview, see The Ratification of the Maastricht Treaty: Issues, Debates and Future Imphications (Finn Laursen \& Sophie Vanhoonacker eds., 1994). Even if such referenda took place in all Member States-and they did notthey should not be analogized to a constitutional transfer of sovereignty that might occur on the national level, from the "people" to national parliaments or courts. Constitutional amendment (whether by referendum or not) was necessary as a matter of domestic law, not because the several European "peoples" intended to create a separate entity with independent constitutional status, but because the revised EC Treaty permitted the exercise of an autonomous rulemaking power outside the confines of the nation-state, thus infringing upon national sovereignty. See, e.g., the decision of the French Conseil constitutionnel, no. 97-394 DC, 31 déc. 1997, Cons. const., Rec. 344 (holding that France needed to amend its constitution prior to the entry into effect of certain provisions of the Treaty of Amsterdam of 1997, following the same logic that the Conseil apphied to the Maastricht Treaty in Decision no. 92-308, 9 avril 1992, Cons. const., Rec. 55).

30. See infra Part I.A on political-legal versus democratic legitimation, especially notes 66-76 and accompanying text. The Community has considerably expanded the powers of the elected European Parhiament as a ineans of introducing democratic control, but this effort is highly problematic for both practical and theoretical reasons. See generally infra Part IV.

31. See infra Part II. This characterization of the Community is, in inany senses, a return to an original understanding of European integration as, fundamentally, an executive-technocratic entity-that is, before the claim of constitutionalism invaded much of the legal and scholarly discourse. On the original executive-technocratic character of the Community, see William Wallace \& Julie Smith, Democracy or Technocracy? European Integration and the Problein of Popular Consent, 18(3) W. Eur. Pol. 137, 143 (1995) (describing the nature of the Community envisioned in the $1950 \mathrm{~s}$ as one of "[e]nlightened administration on behalf of uninformed publics, in cooperation with affected interests and subject to the approval of national governinents"). Froin the perspective of parhamentary control (both national and European), it could well be said that the roots of the democratic deficit are to be found in the original executive and technocratic power structure of the Treaty. See J.H.H. Weiler, The Transformation of Europe, 100 Yale L.J. 2403, 2430 (1991) [heremafter Weiler, Transformation]. Indeed, not only did the Community mirror the changing balance of power in the administrative state at the national level in the 1950s and 1960s, but it fostered this shift as well. See 
The constitutionalist interpretation of the Community-the position of the European Court of Justice-unjustifiably imputes a kind of independent legitimacy to Community institutions that they ultimately do not possess apart from delegations made by the Member States. In the development of its legal doctrines over four decades, the ECJ has proceeded in ways that at times imply that this mediated relationship with the source of the Community's sovereign power did not exist, ${ }^{32}$ even though the absence of a democratic relationship with the peoples of the various Member States is perhaps the most persistent and troubling aspect of European constitutionalism. The EGJ has attempted to circumvent the absence of democratic legitimacy in the Community through a sort of rhetorical sleight of hand, by speaking of the EC's constitutional character as "based on the rule of law," in which the Court itself serves as the ultimate legitimating mechanism, rather than on democratic control. ${ }^{33}$ By asserting, however, that the institutional legitimacy of the Community results primarily from forms of legal rather than democratic control, the ECJ in fact betrays the limitations of its constitutionalist analogy and points to the administrative character of the EC.

Despite the flaws in its constitutionalist approach, it nevertheless needs to be acknowledged that the Court has been a highly successful agent of European integration for much of its history. In the three decades following the EEC's establishment in 1957, the Member States largely acquiesced in the Court's effort to elaborate autonomous supranational norms through the development of such fundamental doctrines as direct effect, supremacy, and implied powers, each of which helped to lay the legal foundation upon which subsequent political integration could build. ${ }^{34}$ And yet, despite this considerable achievement, it must equally be acknowledged that over the last decade the judicial effort to constitutionalize the Community has run up against a number of problematic political realities as the Member States have reasserted their primary role in the integration process. As European integration shifted from a judicial to a more political mode in the late 1980 s and early 1990 s, the Member States introduced a number of structural and substantive legal

Curtin, Postnational Democracy, supra note 9, at 45 ("European integration has considerably increased the power of (national) administrations while making it much more difficult for national parliaments to exert their powers of control."); see also Jose de Areilza, Sovereignty or Management? The Dual Character of the EC's SupranationalismRevisited, Harvard Jean Monnet Chair Working Paper Series no. 2/95, at 5 <http:// www.law.harvard.edu/Programs/JeanMonnet/papers/95/9502ind.html> (referring to "a growing distortion on [sic] the national vertical and horizontal mechanisms of division of powers, as well as the weakeming of other internal democratic checks and balances") (print-out of the online version on file with the Columbia Law Review); see also Paul D. Marquardt, Deficit Reduction: Democracy, Technocracy, and Constitutionalism in the European Union, 4 Duke J. Comp. \& Int'l L. 265, 269-70 (1994) [hereinafter Marquardt, Deficit Reduction].

32. See generally infra Part VI.B-C.

33. Opinion 1/91, 1991 E.C.R. I-6079, 1-6102 para. 21.

34. See generally infra Parts III.A and VI.B. 
changes that are difficult to square with the constitutionalist perspective of the ECJ. These include the insertion of the so-called "subsidiarity" principle into the EC Treaty, the establishment of the "pillar structure" to govern the relationship between the supranational $\mathrm{EC}$ and the intergovernmental EU, and the move toward "variable geometry" in a number of substantive domains through opt-outs, derogation rights, and procedures for "closer cooperation" among certain Member States. ${ }^{35}$

The constitutionalist perspective cannot adequately account for these sorts of changes other than to see them as troubling deviations from the constitutionalist ideal-as evidence of a "Europe of bits and pieces." 36 This Article asserts that an administrative perspective better explains the recent evolution of the EC's institutional law, by viewing these changes as part of a political and legal strategy by which the Member States (the democratically-legitimate principals in the system) have sought to limit the normative autonomy of the Community as their agent, while not unduly impeding the progress of legislative and regulatory harmonization. ${ }^{37}$ This balancing act-characterized by the desire to retain a measure of political control while also allowing integration to proceedis particularly pronounced in the so-called "comitology system," or the regulatory committee system through which much of the subordinate legislation of the Community must now pass. ${ }^{38}$ As one observer notes, the dominant forms of policy coordination in the Community (i.e., the "Iong Community tradition of administration by committees of experts"39) are

35. See infra Part III.C. As Moravcsik \& Nicolaidis, supra note 24, have pointed out, when in 1988 Margaret Thatcher called for a "multi-track" Europe, her position was "dismissed as the height of Euroscepticism." Id. at 35. However, "[i]n the decade that followed, the debate over Europe has been turned on its head. Today it is the more federalist countries that demand differentiation and flexibility-now termed 'differentiated solidarity', 'avant-garde', 'federal core', or 'enhanced co-operation'." Id.

36. See, e.g., Deirdre Curtin, The Constitutional Structure of the Union: A Europe of Bits and Pieces, 30 Common Mkt. L. Rev. 17 (1993) [hereinafter Curtin, A Europe of Bits and Pieces]; see also Moravcsik \& Nicolaidis, supra note 24, at 15-16 (describing widespread dissatisfaction among European "federalists" with the Treaty of Amsterdam); Jo Shaw, The Treaty of Amsterdam: Challenges of Flexibility and Legitimacy, 4 Eur. L.J. 63, 80-8I (I998) (describing variable geometry, on the one hand, as a "typically technocratic solution," and, on the other, as evidence that "the 'constitution' of the EU is an evolving rather than fixed entity").

37. Cf. Moravcsik \& Nicolaidis, supra note 24, at 33 ("What governments and the public seem to desire today-as they always have-is a European structure that solves practical problems while undermining state sovereignty to the minimum extent possible.").

38. The Council of Ministers established the comitology system to control the subdelegation of additional rulemaking powers to the European Commission. Rather than simply confer such powers on the Commission outright-as permitted under Article 145 (now Article 205) of the EC Treaty-the Council issued the Comitology Decision on July 13, 1987, Council Decision 87/373/EEC, 1987 O.J. (L 197) 33, which outlined three alternative types of committee procedures for the adoption of subordinate legislation. See generally infra Part V.C, especially notes 281-282 and accompanying text.

39. Sauter, supra note 7 , at 68 . For further historical background and a legal overview, see Ellen Vos, The Rise of Committees, 3 Eur. L.J. 210 (1997). 
"difficult to fit into existing constitutional categories, and even more difficult to square with democratic legitimacy: a tough challenge to [European] constitutional theory." ${ }^{0}$ The administrative perspective advocated here, it is hoped, can provide a means to overcome the disconnect between much of the prevailing-and recognizably inadequate-constitutionalist discourse regarding the Community and the administrave reality of its institutions. ${ }^{41}$

My analysis involves three basic elements. First, I examine, in administrative law terms, the absence of democratically-legitimate political control over the Community's "legislative" output. I then explore changes in the institutional law of the Community that, I argne, the Member States implemented in response to that absence. ${ }^{42}$ Second, I consider two widely-discussed alternative strategies to legitimize Community action: democratization through an increase in the powers of the European Parliament, ${ }^{43}$ and "non-hierarchical" legitimation through an increase in transparency and participation rights in the Community regnlatory process. $^{44}$ I conclude, however, that both strategies are unpromising because each ultimately depends-although for different reasons-on the establishment of legitimate political control outside the confines of the nationstate, which is a problematic proposition at this point in Europe's history. Third and finally, I turn to methods of Treaty interpretation as means of promoting democratic legitimacy, focusing particularly on the extent to which the institutions of the Community-qua supranational administrative agency-are entitled to deference in their interpretation of the scope of the Community's delegated authority relative to the more democratically-legitimate Member States. ${ }^{45}$

It is on this third point that one should discern what I regard to be the most important legal consequence of my analysis. Because the European Community's legislative process should be viewed as primarily administrative in character, it should not enjoy the deference usually accorded a normal constitutional legislature, something akin to the rational basis test in the United States, which has been the ECJ's effective practice to date. ${ }^{46}$ This Article argnes for the abandonment of the ECJ's "prefer-

40. Sauter, supra note 7, at 68 . For an analogous view from within the ECJ itself, see David A.O. Edward, What Kind of Law Does Europe Need? The Role of Law, Lawyers and Judges in Contemporary European Integration, 5 Colum. J. Eur. L. 1, 13 (1998-1999) (arguing that the "structure [of governance in the EC/EU] does not fit well with conventional theories of separation of powers or of federal structures").

41. For a similar effort to overcome this sort of disconnect, see generally Moravcsik \& Nicolaïdis, supra note 24.

42. See infra Part III.

43. See infra Part IV.

44. See infra Part V.

45. See infra Parts VI \& VII.

46. For further discussion, see infra Part VI.C.2, especially notes 410, 417-434 and accompanying text. The Court takes a less deferential line only where one branch (generally the Council) argues for a "legal basis" that constrains Community coinpetence and maximizes Member State control. See infra notes 373-377 and accompanying text. 
ence for Europe," the method that has prevailed over nearly four decades, and the application of a general interpretive presumption against the Community's normative autonomy. In other words, where there is ambiguity in the EC Treaty with regard to the relative balance of power between the Community and the Member States, European courts should favor any reasonable interpretation that maximizes Member State control, because national officials are the more legitimate decisionmakers. ${ }^{47}$

As further support for this presumption, I look specifically to the subsidiarity principle, which the Member States added to the EC Treaty via the Treaty on European Union (TEU) in 1992.48 European courts should regard subsidiarity, at a minimum, as an interpretive principle akin to the nondelegation doctrine in the United States. ${ }^{49}$ The purpose of viewing subsidiarity in this way would not be to create insurmountable obstacles to supranational delegation, but rather simply to avoid Treaty constructions that amount to democratically problematic, open-ended transfers of normative power to the Community's essentially administrative institutions.

Along the same lines, because the ECJ's own adjudicative authority is intimately bound up with the administrative character of the Community, this Article argues that the European Court of Justice should not possess exclusive jurisdiction to rule on the extent of the Community's delegated legislative authority - the so-called Kompetenz-Kompetenz-which the ECJ has effectively claimed to date. Rather, the Community must develop a system to resolve conflicts between the two orders of jurisdiction (national and supranational) in a manner that respects the legitimate prerogatives of both spheres of governance. I thus propose the establishment of a "European Conflicts Tribunal" akin to the French Tribunal des Conflits to resolve disputes over competences. ${ }^{50}$

47. The inspiration for this presumption is drawn from the opinion of the United States Supreme Court in Chevron U.S.A., Inc. v. Natural Resources Defense Council, 467 U.S. 837 (1984). My outlook is similar to Paul Stephan's proposed legal "skepticism" toward internationally-produced legislation. See Paul B. Stephan, Accountability and International Lawmaking: Rules, Rents and Legitimacy, 17 Nw. J. Int'l L. \& Bus. 681, 732 (1996-1997). See infra Part VI.A.

48. See generally George A. Bermann, Taking Subsidiarity Seriously: Federalism in the European Community and the United States, 94 Colum. L. Rev. 331 (1994) [hereinafter Bermann, Taking Subsidiarity Seriously]. Since the entry into force of the TEU, EC Treaty Article 5 (ex Article 3b) has provided the following:

In areas which do not fall within its exclusive competence, the Community shall take action, in accordance with the primciple of subsidiarity, only if and in so far as the objectives of the proposed action cannot be sufficiently achieved by the Meinber States and can therefore, by reason of the scale or effects of the proposed action, be better achieved by the Community.

49. For the American nondelegation doctrine analogue, see Industrial Union Dep't v. American Petroleum Inst, 448 U.S. 607, 646 (1980) [heremafter Benzene]. For further discussion of the subsidiarity/nondelegation comparison, see infra notes $459-487$ and accompanying text.

50. See infra Part VII. 
Cognizant, however, that "not all legal problems can be solved legally,"51 I would build an additional, formalized political check into the otherwise essentially judicial conflicts process that I outline in this Article. In the event that a dissenting Member State is dissatisfied with a legal decision of the Conflicts Tribunal, it should have the right to appeal the matter to a political body comprised of the heads of state or government of the Member States, the European Council. ${ }^{52}$ If the Member State concerned cannot negotiate a satisfactory political solution within the European Council, then it should have the right-subject to significant procedural conditions precedent-to opt out of the disputed legislation. ${ }^{53}$ This sort of opt-out right would be another manifestation of the emerging variable geometry in Community law, but more importantly it would reinforce political responsibility at the national level for the normative output of the Community, thus augmenting its democratic legitimacy. ${ }^{54}$

\section{The American Perspective}

Much (but obviously not all) of the inspiration for the administrative perspective brought to bear here is of American origin, which is perhaps understandable given the nationality of the author. Looking at the EC from an American administrative law perspective, however, is not inerely an analytical conceit: Many influential European commentators, as a means of addressing the democratic deficit in Europe, increasingly draw inspiration from what they perceive to be the American model of participatory, non-hierarchical administration. ${ }^{55}$ The problem, however, is

51. Neil MacCormick, The Maastricht-Urteil: Sovereignty Now, 1 Eur. L.J. 259, 265 (1995) [hereinafter MacCormick, Sovereignty Now].

52. This body also includes each State's foreign ministers as well as the President of the European Coinmission and the Commissioner for External Affairs. It is charged with defining "the general political guidelines" of the European Union. TEU art. 4 (ex art. D).

53. See infra notes 517-521 and accompanying text.

54. See infra notes 517-521 and accompanying text.

55. The work of Giandomenico Majone provides the inost prominent example. See, e.g., Giandomenico Majone, Europe's "Democratic Deficit": The Question of Standards, 4 Eur. L.J. 5, 18-22 (1998) [hereinafter Majone, "Democratic Deficit"]; Giadomenico Majone, The European Community: An "Independent Fourth Branch of Government"? in Verfassungen für ein Ziviles Europa 23 (Gert Brüggemeier ed., 1994) [hereinafter Majone, Independent Fourth Branch]; Giadomenico Majone, The Rise of the Regulatory State in Europe, 17 W. Eur. Pol. 77, 98 (1994) [hereinafter Majone, Regulatory State]; see also Giadomenico Majone, Temporal Consistency and Pohicy Credibility: Why Democracies Need Non-Majoritarian Institutions 6-8 (European Univ. Inst, Working Paper RSC No. 96/57, 1996) [hereinafter Majone, Teinporal Consistency] <http:// www.iue.it/RSC/WP-Texts/96_57thtml> (print-out of the online version on file with the Columbia Law Review). For similar views, see Michelle Everson, Administering Europe?, 36 Common Mkt. L. Rev. 195 (1998) [hereinafter Everson, Administering Europe?]; Michelle Everson, Independent Agencies: Hierarchy Beaters?, 1 Eur. L.J. 180 (1995) [hereinafter Everson, Independent Agencies]; see also P.P. Craig, Deınocracy and Rule-Making within the EC: An Einpirical and Normative Assessment, 3 Eur. L.J. 105 (1997); Christian Joerges \& Jürgen Neyer, From Intergovernmental Bargaining to Dehberative Political Processes: The Constitutionalisation of Comitology, 3 Eur. L.J. 273 (1997). For an American 
that several of these commentators have failed to appreciate fully the complex relationship between legitimate political control and judicial review in American administrative law, emphasizing instead judicially-enforced transparency and participation rights as the principal means of legitimizing technocratic autonomy. ${ }^{56}$ Selectiveness with regard to the American example in this case may risk mistaken or incomplete prescriptions for Europe in its search to overcome the democratic deficit, particularly given the critical absence of legitimate hierarchical control within the Community.

It is my hope that the difficult question of legitimacy in Europe may serve as a point of entry into a broader scholarly discussion of the appropriate means of controlling delegated normative power in any supranational body, a debate in which American legal scholars must participate as well. The phenomenon of supranational delegation raises a number of questions of political and historical complexity, and I do not claim to advance anything approaching a complete answer to them here. Rather, the advent of supranationalism continues to demand the insights of historians, constitutional and political theorists, and social scientists, as well as specialists in public international law, international trade, and international relations. Nevertheless, I believe that the administrative perspective developed in this Article may provide a guide for future research, or at least a number of working hypotheses regarding the legal nature of this important historical phenomenon.

The European experience strongly suggests that the key obstacle to supranational legitimacy is the difficulty in reproducing democraticallylegitimate, hierarchical control outside the confines of the nation-state. The problem of legitimate political control is, in turn, intimately bound up with complex questions of the relationship between demos, democracy, and national political institutions as symbols of popular sovereiguty. .57 For those who insist on viewing supranational bodies in constitutionalist terms, the challenge is to reconceive democracy outside the nation-state-perhaps by redefining the very meaning of demos ${ }^{58}$-in order to achieve, as Deirdre Curtin puts it, "postnational democracy." 59 In the case of the EC/EU, in my view, there remain siguificant cultural-historical obstacles to building such a postnational democracy, even if one cannot deny that some important strides have been made toward the formulation of a specifically European demos. ${ }^{60}$

contribution, see generally Martin Shapiro, Codification of Administrative Law: The U.S. and the Union, 2 Eur. L.J. 26 (1996).

56. See infra notes 119-124, 313-321 and accompanying text.

57. See infra Part IV.

58. Joseph Weiler has advocated a redefinition of the notion of "demos," or peoplehood, in order to create the possibility of democratic legitimacy at the Community level. See Weiler, Demos, supra note 28.

59. Curtin, Postnational Democracy, supra note 9.

60. See infra notes 231-233 and accompanying text. 
The emergence of such a demos is admittedly a dynamic process. Nevertheless, in Europe as elsewhere, democratic legitimacy depends on the popular perception of the existence of a political demos as such, as well as on the belief that governing institutions symbolize or express the sovereignty of the demos in a constitutional sense. At the European level, as long as political identity continues to cling to the nation-state, and thus to its institutional structures, as expressions of popular sovereignty, the status of the EC/EU as a self-legitimating "constitutional" level of governance will remain tenuous. ${ }^{61}$ In the interim, the Community will continue to be essentially of an administrative character-that is, it will continue to be a technocratic body exercising delegated normative power-and public law doctrines governing Community action should be reformulated to reflect this reality. ${ }^{62}$

Before other regional free-trade blocs, or the global community more generally, proceed further down the supranational path, we must examine seriously whether we possess the means of legitimizing supranational normative power-specifically rulemaking power-in a way that adequately accounts for the political and cultural tensions that arise when such power is exercised by non-national decisionmakers. Where, as here, the central concern is democratic legitimacy-that is, the nature of the relationship between an at least perceived-to-be "sovereign" people and the possessors of delegated normative power-I would argne that the administrative characterization of supranationalism holds true regardless of whether the normative power in question is adjudicative (as in the WTO) or is also legislative (as in the EC). Administrative law, rather than strained constitutionalist analogies, may thus provide the most promising source of principles to mediate between the legitimate needs of increased international regulatory cooperation on the one hand, and the persis-

61. On the persistence of national identity, see Matieu Deflem \& Fred C. Pampel, The Myth of Postnational Identity: Popular Support for European Unification, 75(1) Social Forces 119 (1996) (empirical study arguing in favor of continued importance of national identity); Chris Shore, Transcending the Nation-State? The European Commission and the (Re-) discovery of Europe, 9(4) J. Historical Sociology 473 (1996) (a critical appraisal of the concept of European identity which questions whether the efforts of the EC to construct a post-nationalist political order in Europe is feasible or politically desirable); Stephen Wood, Building "Europe": Culture, History and Politics, 11(3) J. Historical Sociology 397 (1998) (arguing that nations remain the base line for conceptions of belonging and political legitimacy in Europe).

62. Although this Article suggests that the Community lacks constitutional and democratic legitimacy, it does not argue that the EC is, as a consequence, an illegitimate producer of legal norms. The Coinmunity clearly possesses a kind of administrative legitimacy, rooted in the expertise of its technocrats and their capacity, subject to forms of indirect political and legal controls, to produce efficient norms responsive to social needs. Moreover, the shared inemory of Europe's own destructiveness in the first half of the century continues to lend legitimacy to the integration effort and further provides popular and cultural underpinnings to what is otherwise a highly elite, bureaucratic enterprise. See infra note 232. 
tence of the sovereign nation-state as a cultural category on the other-a tension that arguably exists in any supranational body.

\section{Supranational Delegation and Democratic Legitimacy: General Considerations}

\section{A. Legitimacy in National Administrative Institutions}

The practice of delegation is so common in modern administrative states that one could probably describe it as "universal ... in most if not all complex societies." 63 Despite its probable universality, however, the power of unelected administrators to make regulatory norms-notably the power to make general rules in a quasi-legislative sense-is inescapably problematic from the standpoint of democratic legitimacy. Admittedly, measuring legitimacy is a difficult task. In a sociological sense, it may be described as "a broad, empirically determined societal acceptance of the system." 64 However, specifically democratic legitimacy, as that term is used in this Article, also possesses an important formal-institutional dimension, one relating to the degree of perceived connection between the people and the possessors of normative power. There are two fundamental criteria that I assert are essential to establishing that connection, both of which administrative power fails to meet. First, administrative agencies do not derive their power directly from a constitutional delegation of legislative authority from the people; rather, they derive it indirectly from the people through an enactment by the people's elected representatives. ${ }^{65}$ Second, agencies do not depend directly on periodic popular approvalthat is, they do not depend directly on the vote-for their continuing legitimacy.

This is not to say, however, that legislative power delegated to administrative institutions is therefore necessarily illegitimate in a sociological

63. Peter L. Strauss, From Expertise to Politics: The Transformation of American Rulemaking, 31 Wake Forest L. Rev. 745, 747 (1996) [heremafter Strauss, From Expertise to Politics].

64. See Weiler, Transformation, supra note 31 , at 2469 . For a succinct overview of similar views in the social sciences, see Marquardt, Deficit Reduction, supra note 31, at 272-74.

65. My notion of constitutional delegation is similar to Bruce Ackerman's notion of constitutional moment or, rather, of "historic moments of successful constitutional politics." Bruce Ackerman, We the People: Foundations 23 (1991). According to Ackerman, however, such moments need not take the form of an explicit constitutional adoption or revision. Moments of overwhelming popular support can confer special constitutional legitimacy on reformist political representatives and the constitutional changes, both substantive and procedural, sought to be effected. 1 would argue, however, that such moments must hold a place in the popular memory as constitutional-that is, they must be remembered not as "routine lawmaking" but as "higher lawmaking"-in order to hold the status of a constitutional delegation. See generally Peter L. Lindseth, Law, History and Memory: "Republican Moments" and the Legitimacy of Constitutional Review in France, 3 Colum. J. Eur. L. 49 (1996-1997) [hereinafter Lindseth, Law, History and Memory]. 
sense. It means only that the legitimacy of administrative rulemaking cannot, formally speaking, be termed democratic. Rather, at the national level, the institutional legitimacy of administrative bodies is generally mediated through the branches of government that are themselves endowed with constitutional authority, whether democratic (i.e., executive or legislative) or judicial. ${ }^{66}$ The formal-institutional legitimacy of administrative power thus depends primarily on political and legal mechanisms. It is rooted first in a lawful legislative enactment and thereafter relies on some combination of hierarchical political control by the executive, direct legislative oversight, and judicial review before courts or specialized tribunals, to ensure that the rules produced in the administrative sphere fall within the original legislative mandate and do not violate the rights of individuals or other private interests. Instead of speaking of democratic legitimacy in the administrative context, therefore, we often speak simply of accountability - that is, not of legitimacy per se but of its substitute.

Of course, neither political oversight nor judicial review, standing alone, provides a complete answer to the democratic concerns raised by delegation to administrative bodies. Agencies often enjoy a significant degree of independence, either in a formal legal sense or as a consequence of organizational complexity, thus undermining the possibility of hierarchical political oversight by democratically-legitimate officials. ${ }^{67}$ Moreover, the incentives for citizens to inform themselves about the stakes of regnlatory policy may be weak, as may be the public's capacity to monitor the activities of elected representatives who purportedly supervise administrative action. ${ }^{68}$ This means that the threat of popular mobilization in the electoral arena over regnlatory policy disagreements may, in some respects, be simply a background constraint at best. ${ }^{69}$

Judicial review, when combined with legally mandated transparency and participation rights of interests affected by administrative action, may do much to mitigate these problems, but does not eliminate them. Transparency and participation rights undoubtedly provide a check on the diffused and fragmented exercise of normative power in the modern state; indeed, the increasing importance of such rights may reflect a

66. See generally Peter L. Strauss, The Place of Agencies in Government: Separation of Powers and the Fourth Branch, 84 Colum. L. Rev. 573 (1984) [hereinafter Strauss, The Place of Agencies].

67. It should be stressed that hierarchical political control need not mean highly centralized control. More subtle, decentralized control mechanisms are possible. In the sense used here, "hierarchical" means only that some electorally accountable body (executive or legislative) retains the ultimate political responsibility for choices made (whicl may include decentralization).

68. See Susan Rose-Ackerman, American Administrative Law Under Siege: Is Germany a Model?, 107 Harv. L. Rev. 1279, 1280 (1994) [liereinafter Rose-Ackerman, Is Germany a Model?].

69. See Susan Rose-Ackerman, Controlling Environmental Policy: The Limits of Public Law in Germany and the United States 66 (1995) [hereinafter Rose-Ackerman, Controlling Environmental Policy]. 
transformation of the very nature of representative government away from a hierarchical, plebiscitarian model to one significantly more decentralized and neo-corporatist. ${ }^{70}$ A citizen's-or, maybe more importantly, a group's-right to participate directly in the exercise of delegated rulemaking authority (through, for example, American-style "notice and comment" procedures) involves a kind of quasi-democratic discipline, assuming that the agency is under a legal obligation to take that participation seriously and respond in a meaningful way to germane comments by outsiders, perhaps even by modifying the proposed subordinate legislation as a consequence. ${ }^{71}$ The legal enforcement of such rights in the courts can, however, compound the shortcomings of administrative accountability if equally unaccountable judges devise means to substitute their judgement for that of the agency under the guise of promoting "reasoned decisionmaking," or if they use judicial review to impose excessive procedural requirements that impede lawful rulemaking. ${ }^{72}$

Given these limitations, political and legal controls can only be said to promote administrative accountability if they operate in combination. ${ }^{73}$ From a democratic standpoint, however, the more important of these two control mechanisms is clearly hierarchical oversight by democratically-legitimate political officials. The reason is simple: Whether in a presidential or parliamentary system, the executive and the legislature are at least perceived to be ultimately responsible to the people in some reasonably direct sense, whereas judges are not. ${ }^{74}$ Hierarchical control by elected officials provides the administrative sphere with the necessary perceived linkage to the people as a whole, a linkage that judicial enforcement of the transparency and participation rights of particular interests, standing alone, simply cannot. ${ }^{75}$ This sort of linkage is especially necessary when the regulatory question entails a dispute over values or the allo-

70. See generally Joshua Cohen \& Charles Sabel, Directly-Deliberative Polyarchy, 3 Eur. L.J. 313 (1997); see also Janne Haaland Matláry, New Forms of Governance in Europe? The Decline of the State as the Source of Political Legitimation, 30 Cooperation \& Conflict 99, 114 (1995).

71. Strauss, From Expertise to Politics, supra note 63, at 759-60.

72. Pierce, supra note 12 , at 1266 .

73. On the need for a balance between hierarchical and judicial control, see Peter $L$. Lindseth, Comparing Administrative States: Susan Rose-Ackerman and the Limits of Public Law in Germany and the United States, 2 Colum. J. Eur. L. 589, 617-18 (1996) [hereinafter Lindseth, Comparing Administrative States] (review essay).

74. Of course, one might argue that in a parliamentary system the cabinet is not directly responsible to the people in the same sense as the chief executive is in a presidential system. However, even in a parliamentary system, citizens cast their votes in particular constituencies generally with the ain of putting a particular party or governing coalition either into power, or, perhaps more importantly, out of power. The pohitical decisions of the executive in a parliamentary system are thus clearly subject to direct voter approbation, even if citizens technically vote only for particular legislators.

75. Cf. Chevron U.S.A., Inc. v. Natural Resources Defense Council, Inc., 467 U.S. 837, 865 (1984) (noting that " $[w]$ hile agencies are not directly accountable to the people, the Chief Executive is, and it is entirely appropriate for this pohitical branch of the Government to make [administrative] pohicy choices," rather than the courts). 
cation of scarce resources; that is, where the question is essentially political rather than technical. It is hierarchical political control, first and foremost, that gives policymaking in the administrative sphere a democratic veneer, if not full democratic legitimacy. Judges must therefore take cognizance of the presence or absence of democratically-legitimate political control in determining the appropriate scope of judicial review of administrative action. ${ }^{76}$

\section{B. Legitimacy in Supranational Institutions}

Perhaps unsurprisingly, the legitimation of supranational normative power is significantly more complicated than what one finds at the national level, taking us out of the realm of formal-institutional legitimating mechanisms into the more complex realm of understanding the sociological legitimation of administrative governance. Supranational delegation, even in pursuit of the valid goal of international cooperation and coordination, is sociologically problematic, I argue, because it undermines an essential but little-acknowledged cultural underpinning of the modern administrative state. Administrative agents on the national level, despite their lack of an electoral relationship with the people, and despite a significant degree of formal or legal independence from political oversight, nevertheless enjoy a degree of implicit popular confidence owing to their membership in the same national political community-the same demos-with a shared history, a shared legal and political tradition, and, presumably, a shared commitment to the ultimate national well-being. ${ }^{77}$ When normative power is exercised outside the confines of the nationstate, this cultural and historical foundation of administrative power is absent.

This absence arguably accentuates the need for legitimate political control over supranational decisionmaking. However, although a particular country's nationals may in fact ultimately hold their domestic representatives responsible for decisions made at the supranational level, the actual control over such decisions may well be diffused throughout supranational institutions and policy-making networks in which no single participating state or its representatives have a decisive voice, in either a legal or practical sense. ${ }^{78}$ Similarly, the objects of regulation will no longer be strictly national but supranational, often rooted in a commitment to abstract economic values-free trade, efficient markets-that many people either poorly understand or fear and disparage as alien and technocratic. ${ }^{79}$ Regardless of the apparent efficiency of the new regulatory arrangements at the supranational level measured in wealth-maximization terms, the threat of social or political "backlash" against a purportedly

76. See Lindseth, Comparing Administrative States, supra note 73, at 618.

77. For further discussion of the concept of the demos, see infra Part IV, discussing extensively the thesis advanced in Weiler, Demos, supra note 28.

78. This is, in fact, the essential characteristic of autonomous supranationalism.

79. Cf. Sand, supra note 8 , at 286. 
alien decisionmaking process is always latent in a supranational system. ${ }^{80}$ More importantly, the threat of backlash may become an active concern as the independence of the supranational decisionmaking process becomes more popularly apparent.

The European experience since the mid-1980s is instructive. It suggests that when supranational institutions gain a significant degree of legal and practical autonomy from national control, the political and cultural repercussions may be profound, even if the economic benefits are, in theory, generally positive. Even in the most ardently "pro-European" of countries, such as France and Germany, significant minorities cutting across traditional ideological lines have emerged with very serious doubts about the value of-indeed with strong hostility toward-the further transfer of rulemaking power beyond the confines of the nation-state. ${ }^{81}$ Should some precipitating event, such as a major economic downturn, place Europe's supranational institutions under significant strain, these legitimacy concerns could turn into a legitimation crisis in which the very idea of supranational normative power may be brought into serious question. .2 $^{2}$

80. On the need to incorporate the threat of backlash into efficiency analysis, see generally Mark J. Roe, Backlash, 98 Colum. L. Rev. 217 (1998).

81. Insofar as the broader phenounenon of supranational delegation (e.g., to the WTO) is concerned, this cross-ideological phenomenon is not confined to Europe. In the United States, Pat Buchanan on the right finds himself in agreement with unlikely allies on the left, such as Ralph Nader and the AFL-CIO, who are united in their opposition to free trade and the transfer of normative power to supranational bodies that it entails. See, e.g., PatrickJ. Buchanan, The Great Betrayal: How American Sovereignty and Social Justice Are Being Sacrificed to the Gods of the Global Economy (1998). For attacks froin the left, see, e.g., Public Citizen v. United States Trade Representative, 5 F.3d 549 (D.C. Cir. 1993); Ralph Nader et al., The Case Against Free Trade: GATT, NAFTA and the Globalization of Corporate Power (1993); The Case Against the Global Economy: And For A Turn Toward the Local (Jerry Mander et al. eds., 1996).

82. The European Monetary Union (EMU) and the introduction of the single currency - the euro-on January 1, 1999, if anything, intensify these risks. The institutional cornerstone of the EMU is the European Central Bank (ECB), a quintessentially technocratic and nontransparent body with "no clear accountability to any other arm of national or European government." Europe's New Currency: Gambling on the Euro, The Economist, Jan. 2, 1999, at 20. The ECB's mandate under the Treaty is "price stability," EC Treaty art. 105, although it is left to the Bank itself to decide what that term ineans. Thus, viewed solely from an institutional perspective, the ECB can only exacerbate the democratic deficit, given its broad discretion in the pohitically delicate domain of monetary policy. But when viewed in light of other aspects of monetary union, notably the so-called Stability and Growth Pact among the eleven participating Member States, the political and economic risks of the euro become even greater. The economic risks flow from the danger of an asymmetrical recession affecting one Meunber State more than others. The political risks, in turn, flow from the inability of the inore-severely affected Member State to take fiscal measures to counteract the recession, since resort to such measures is severely constrained by the Stability Pact. As a major European newsmagazine recently put it: "The danger that this raises is that in the event of a sharp recession in one or more countries, there will then be a pohtical reaction against the EU itself. The Union as a whole, and other euro nnembers, will be blamed for the victim's inability to moderate its recession." Leaders: Europe's Adventure Begins, The Economist, 
Undoubtedly, as an empirical matter the increasing importance of supranational normative power has strained the idea that the nation-state is the presumptive locus of sovereignty. ${ }^{83}$ To some observers, in fact, the diffusion and fragmentation of normative power that characterizes modern governance-not just to the supranational level but to the subnational level as well-now means that the idea of the "sovereign" nationstate is an anachronism. ${ }^{84}$ By extension, one might argne, the corresponding notion of supranational delegation is of equally limited analytical utility because it implicitly takes the sovereign nation-state as the normative baseline. ${ }^{85}$ There is, however, a basic flaw in this argument. Although terms like national sovereignty and delegation may be descriptively anachronistic, they retain validity in a cultural sense. ${ }^{86}$ By this, I mean that they retain their power to order thinking-to shape popular understandings of, and therefore social and political responses to, the changing political structures associated with globalization. ${ }^{87}$ As a conse-

Jan. 2, 1999, at 16. One possible political consequence would be that in many European countries political voices presently considered to be on the anti-European extreme could receive a more sympathetic hearing among supporters of the "inainstream" parties. See, e.g., Marlise Simons, On Far Right, A Soft Voice Undermines French Center, N.Y. Times, Apr. 14, 1998, at A6.

83. See MacCormick, Sovereign State, supra note 2; MacCormick, Sovereignty, Democracy and Subsidiarity, supra note 2; Stephan, supra note 47; see also Matláry, supra note 70, at 110 (speaking of the state as a formal-legal reality that is in decline empirically).

84. See, e.g., MacCormick, Sovereign State, supra note 2, at 16 ("it seems obvious that no state in Western Europe any longer is a sovereign state"); MacCormick, Sovereignty, Democracy and Subsidiarity, supra note 2, at 95 ("Sovereignty and sovereign states, and definitions of law in terms of sovereignty and the state, have been but the passing phenomena of a few centuries. Their passing is by no means regrettable."); see also Armstrong, supra note 17, at 169; Sand, supra note 8, at 285; Areilza, supra note 31, at 20.

85. Cf. Armstrong, supra note 17, at 168 ("[T] he language of delegation is deployed $\mathrm{im}$ order to maintain the centrality of the nation-state as the defining variable of EU integration."); Wiener, supra note 17, at 298 (generally describing interpretations of the $\mathrm{EC} / \mathrm{EU}$ rooted in administrative law as state-centric "[c]onceptual remnants" that are "all too often unisleading when applied as tools in the debates over politics and policy-making in polities other than modern nation-states").

86. They belong to a cultural system of interpretation in the sense described supra note 11 .

87. Professor MacCormick, perhaps madvertently, offers a concrete example of this pluenomenon. See MacCormick, Sovereign State, supra note 2, at 16, in which lie refers to a leading article that appeared in the Daily Telegraph whicb praised the then-Chancellor of the Exchequer, Norman Lamont, "for his absolute adlierence to the principle of "fiscal sovereignty' while exbibiting sensible flexibility about some process of harnonisation of taxes" in the Community. MacCormick's aim was to show that, while "no state in Western Europe is any longer a sovereign state," id., opinion leaders still cling (mistakenly) to the notion. MacCormick's point is well taken but he misses the full implications of his example. Popular conceptions of state sovereignty, like those found in the Daily Telegraph's editorial, are an empirical reality in their own right that must be accounted for in any serious discussion of the democratic legitimacy of Community institutions. Another observer, Antje Wiener, also effectively alludes to the cultural importance of state-based notions like sovereignty when asserting that the discursive shift in the social sciences away from the notion of traditional "government" to the purportedly more modern notion of 
quence, particularly when viewed from the perspective of democratic legitimacy, notions like national sovereignty and delegation cannot be ignored or theorized away as descriptively unhelpful or empirically inaccurate. ${ }^{88}$ Despite the pressures for increased international economic integration that drive supranational delegation, "the primary political unit"-at least in a cultural sense-"remains the 'sovereign' nationstate." 89

The problem with supranational institutions, and especially those of the European Community, is not simply that they are "nonmajoritarian"-i.e., non-democratic-like other administrative agencies that lack a direct electoral relationship with the people. ${ }^{90}$ Rather, it is that they are both non-democratic and, more importantly, non-national. As a consequence, they lack the degree of implicit popular confidence that makes administrative autonomy on the national level possible, or at least tolerable. Indeed, upon closer examination, one finds that this issue-which lies at the intersection of politics, law, and national identityis also at the center of Europe's struggle with the so-called democratic deficit.

\section{The Administrative Character of Supranationalism in the EUROPEAN COMMUNITY}

\section{A. Institutional Background: The European Community and the European Union Distinguished}

Most American legal scholars have at least a passing familiarity with European integration and its leading institutions, the European Union

"governance" will remain superficial unless accompanied by a conceptual shift that breaks with "rigid adherence to traditional notions of the national pohity." Wiener, supra note 17, at 298-99 (quoting Everson, Administering Europe?, supra note 55, at 209). The real question, however, is not whether academic ehtes can make the necessary conceptual shift (this, perhaps, is easily accomplished), but whether the broader population can make the same shift. Only then will "governance without government" be viewed as fully legitimate.

88. See infra notes 224-233 and accompanying text (discussing Weiler, Demos, supra note 28). For an analysis sensitive to sovereignty concerns, see Croley and Jackson, supra note 4 , at 212 .

89. Picciotto, Networks, supra note 18 , at 1055 .

90. For an analysis that regards the legitimacy problem in the Community in these terms, see Majone, Independent Fourth Branch, supra note 55, at 24:

The problem of the "democratic deficit" of the Community is by no means unique, although this is the impression given by many disquisitions on the subject. In reality, it is a problem common to all non-majoritarian institutionsindependent regulatory agencies but also courts and central banks. If the problem is more visible at the Community level, this is because regulation is relatively more important there than at the national level.

lt should also he noted that Majone's inclusion of courts in the same category as independent regulatory agencies and central banks is questionable. In most states, the normative power of the judiciary is generally the consequence of a constitutional delegation, conferring on them a degree of institutional legitimacy that agencies or central banks cannot claim, given that they are creatures of legislation. 
and the European Community. However, for most observers outside Europe the structural intricacies and procedural complexities of these bodies remain, if not a mystery, then a source of some confusion. The first bit of confusion usually concerns the basic legal distinction between the EU and the EC itself. The EC is merely a component part of the EU-the first of its three "pillars," as Europeans put it. The second pillar encompasses a common foreign and security policy, while the third extends to cooperation in justice and home affairs, a term that encompasses law enforcement and immigration, among other things. ${ }^{91}$ However, only the first pillar-the European Community-can make a claim to being a truly supranational body with a reasonably autonomous institutional existence of its own. ${ }^{92}$ In so far as the second and third pillars are concerned, the EU has historically been essentially an intergovernmental body, requiring the consent of each Member State before common action can be taken. This requirement preserves, at least in principle, the prerogatives of national sovereignty and control. ${ }^{93}$

The competences of the European Community are confined largely to economic and social regulation; that is, to the enforcement of competition rules and the harmonization of national legislation necessary to achieve an integrated internal market among the EU's fifteen Member States. ${ }^{94}$ The Community possesses a collective "executive" (the European Commission) sitting atop its own bureaucracy; a sort of "twohouse legislature" (the Council of Ministers and the European Parliament); and a "judiciary" (the European Court of Justice and the Court of First Instance). The Commission is appointed for a five-year term by common consent of the Member States, subject to approval by the European Parliament, which is elected for the same five-year term, generally by proportional representation from national lists. ${ }^{95}$ The Commission is headed by the President, nominated by "common accord" of the Member

91. Under the Treaty of Amsterdam, the Community gains significant competences in niany third pillar areas. For a discussion, see infra notes 179-181 and accompanying text.

92. The EU's "first pillar" in fact encompasses the three separate European communities founded in the 1950s: the ECSC, the EC (formerly the European Economic Comnuinity, or EEC), and Euratom. See supra note 19. For simplicity, 1 refer to the entire "first pillar" as the European Community.

93. At the EU level the key institutions are the European Council, a body that meets every six months and includes the heads of state or government, as well as the foreign ministers of each Meniber State, along with the President of the European Commission and the Commissioner for External Affairs; and the so-called Intergovernmental Conferences (1GCs), where Treaty amendments are negotiated. The EU was established in 1992 by the Treaty on European Union (TEU), often called the Maastricht Treaty.

94. There bas, lowever, been significant spill-over into other domains. See infra notes 154-156 and acconıpanying text.

95. The Umited Kingdoin has historically used single-nienıber districts, although it has shifted to proportional representation for the June 1999 elections to the European Parliament. EC Treaty art. 190(3) (ex art. 138(3)). However, EC Treaty Article 190(4) (ex art. 138(4)), as amended by the Treaty of Amsterdam, obligates the European Parliainent to "draw up a proposal for elections . . . with a uniform procedure in all Member States." 
States, and, after the Treaty of Amsterdam, subject to approval by the European Parliament. ${ }^{96}$ Each Commissioner receives a portfolio covering one or more of the Community's directorates-general (in effect, ministries). The Council of Ministers is a variable body, composed of Member State ministers whose domestic portfolios relate to the matter at hand (e.g., on agricultural questions, agricultural ministers, and so on) .97 The Council and the Parliament vote on legislative proposals submitted by the Commission, although it is clearly the Council and the Commission that historically have played the decisive legislative roles.98 Finally, the legal acts of the Community, as well as those of the Member States touching on Community law, are subject to review by the Community judiciary. ${ }^{99}$

96. EC Treaty Art. 214(2) (ex art. 152(2)).

97. A "Committee of Permanent Representatives" (COREPER) assists the Council of Ministers and provides it a permanent presence in Brussels to counterbalance the bureaucratic predominance of the Commission. EC Treaty art. 296 (ex art. 151).

98. The legislative process in the Community is extremely variegated and complex. See, e.g., infra note 131. Nevertheless, it follows one basic inodel: The Commission proposes and the Council disposes. The Council of Ministers thus votes on proposals submitted by the Commission, either by unanimity or qualified majority, depending on the subject matter. However, as discussed infra notes 199-200 and accoinpanying text, the European Parliament has over the last decade assumed an increasingly important legislative role, gaining a true veto in certain domams-under the "co-decision procedure" of Article 251 (ex art 189b) of the EC Treaty-and a suspensive veto in others-under the "cooperation procedure" of Article 252 (ex art. 189c)). The Treaty of Amsterdam has vastly increased the areas subject to the co-decision procedure, leading to the "virtual disappearance of the cooperation procedure." See Michel Petite, The Treaty of Amsterdam, Harvard Jean Monnet Chair Working Paper series, no. 2/98, <http:// www.law.harvard.edu/programs/JeanMonnet/papers/98/98-2-01.html>, at section IV, page 2 (print-out of the online version of file with the Columbia Law Review).

Community legislation comes in two broad forms: regulations and directives. Under Article 249 (ex art. 189) of the EC Treaty, regulations are directly applicable without Member State legislation. By contrast, directives, the inore common form of legislation, require Member State miplementing legislation in order to be "transposed" into national law. Directives are in theory binding only as to the result to be aclieved, leaving the specific form and content of implementation to the discretion of national legislatures. However, the ECJ lias long held that a directive can liave direct effect in a Member State if the deadline for implementation has passed and the directive is unambiguous in its legal terms. See, e.g., Case 41/74, Van Duyn v. Home Office, 1974 E.C.R. 1337.

99. Member States, individual plaimtiffs, and Community institutions can bring action in the ECJ challenging the legality of acts of the Community that are intended to produce legal effects, although the standing requirements and the nature of challengeable acts vary among the possible plaintiffs. See EC Treaty art. 230 (ex art. 173). The ECJ also has jurisdiction to consider the legality of Community acts if a national court refers the question to the ECJ in the context of national litigation. See EC Treaty art. 234(b) (ex art. 177(b)). However, the more important function of the preliminary reference procedure under Article 234 (ex art. 177) is to enable the ECJ to consider the legality of Meunber State norms under Community law. See infra note 349. The Commission can also initiate a direct action against a Member State under Article 226 (ex art. 169) for failure to coinply with an obligation under Community law. 


\section{B. The Limitations of the Existing Descriptive Categories: The Community as Intermational Organization and as Constitutional Polity}

The legal character of the Community remains elusive even to the most knowledgeable observers. The question is persistently asked: Is the EC simply a new kind of international organization or has it evolved into something approaching a federal "constitutional polity" in its own right? No one, of course, opts for either characterization without qualification. Rather, the broadly accepted view is that the Community is sui generis: It "remains something well short of a federal state [but] has become something far more than an international organization of independent sovereigns." 100 Yet despite its sui generis character-despite the fact that the Community "is still a novelty in want of a convincing label"101_these two poles (constitutional polity, international organization) have largely provided the analytical categories that have shaped much of the scholarly and political debate over the history of the Community.

From the standpoint of democratic legitimacy, both perspectives provide a poor guide to the legal nature of the Community's supranational institutions. Lawyers, judges, and legal academics have traditionally tended toward the constitutionalist pole in the debate. ${ }^{102}$ According to this view, the EC has transformed itself from a legal arrangement among sovereign states governed by international law into a vertically-integrated "new legal order"- that is, a kind of constitutional order-as the European Court of Justice so boldly announced in 1963 in Van Gend $\mathcal{E}^{\circ}$ Loos. ${ }^{103}$ The key element in this transformation was the judicial recognition-via doctrines of the supremacy and direct effect of Community law,

100. Anne-Marie Burley \& Walter Mattli, Europe Before the Court: A Political Theory of Legal Integration, 47 Int'l Org. 41, 41 (1993).

101. Dieter Grimm, The European Court of Justice and National Courts: The German Constitutional Perspective After the Maastricht Decision, 3 Colum. J. Eur. L. 229, 229 (1997). Grimm is a judge on Germany's Federal Constitutional Court.

102. For an overview, see Burley \& Mattli, supra note 100 , at $41-42$; Weiler \& Trachtman, supra note 23. For examples, see F.G. Jacobs, is the Court of Justice of the European Communities a Constitutional Court?, in Constitutional Adjudication in European Community and National Law 25 (Deirdre Curtin \& David O'Keeffe eds., 1992); Trevor C. Hartley, Federalism, Courts and Legal Systems: The Emerging Constitution of the European Community, 34 Am. J. Comp. L. 229 (1986); Koen Lenaerts, Some Thoughts about the Interaction Between Judges and Politicians, 1992 U. Chi. Legal F. 93 [hereinafter Lenaerts, Interaction]; Koen Lenaerts, Constitutionalism and the Many Faces of Federalism, 38 Am. J. Comp. L. 205 (1990); G. Federico Mancini, The Making of a Constitution for Europe, 26 Common Mkt. L. Rev. 595 (1989); Eric Stem, Lawyers, Judges, and the Making of a Transnational Constitution, 75 Am. J. Int'l L. 1 (1981); see also Sauter, supra note 7 , at $30-45$.

103. Case 26/62, N.V. Algemene Transp. \& Expeditie Onderneming Van Gend \& Loos v. Nederlandse Admimstratie der Belastingen, 1963 E.C.R. 1, 2 C.M.L.R. 105 (1963). This is perhaps the most famous decision in European law, in which the ECJ held that Article 12 of the EEC Treaty had a direct effect which an imdividual could raise against a Member State, stating memorably that "the Community constitutes a new legal order of international law." Id. at 12, 2 C.M.L.R. at 129. For further discussion, see infra notes 343-349 and accompanying text. 
implied powers, and more recently fundamental rights ${ }^{104}$ - that Community law creates legal obligations that individuals can enforce against the Member States. It is this process that purportedly distinguishes the "constitutional" EC from other international legal regimes, which create obligations enforceable solely among the participating states themselves. Indeed, it is now common for the ECJ explicitly to assert the constitutional character of the Community, calling the EC Treaty the "constitutional charter of a Community based on the rule of law."105

This claim of a constitutional status for the institutions of the Community contains a number of weaknesses. The most fundamental is that there is not yet any European "people"-no demos-in whom sovereignty can be said to have originally resided, which was then constitutionally delegated to the Community without going through the intermediation of the Member States. ${ }^{106}$ Moreover, even if a fully-formed demos were not a prerequisite, there is another basic problem: There has never been any explicit constitutional decision on the part of the peoples of the various Member States to create a self-legitimating, federal constitutional entity at the European level. Several scholars have asserted the need, therefore, for a full-fledged "constitutional convention," or in any case some kind of "constitutional moment" in Europe, in order "to generate (or self-constitute) a democratic European polity."107

Apart from these theoretical criticisms, recent scholarship in a number of social science fields (political science, international relations, political economy, sociology) have also revealed several empirical shortcomings in the constitutionalist perspective. ${ }^{108}$ One strand of the recent social-science literature points to the considerable evidence of the Community's continuing intergovernmental nature, notably at the levels of Treaty amendment and of major harmonization legislation. ${ }^{109}$ In these

104. For a discussion of these doctrines, see infra notes 342-368 and accompanying text.

105. Opinion 1/91, 1991 E.C.R. I-6079, I-6102 para. 21; see also Case C-2/88 Imm., Zwartveld et al., 1990 E.C.R. I-3365, I-3373, para. 16; Case 294/83, Parti écologiste 'Les Verts' v. Parliament, 1986 E.C.R. 1339, 1365 para. 23.

106. See infra Part $\mathrm{V}$.

107. Sauter, supra note 7, at 36 (citing, e.g., Curtin, A Europe of Bits and Pieces, supra note 36); see also Philip Allott, The Crisis of European Constitutionalism: Reflections on the Revolution in Europe, 34 Common Mkt. L. Rev. 439, 490 (1997) (advocating convening of a "Congress of Europe," where "we, the people of Europe, would consider how far we can actualize the unique potentiality of Europe"). This, of course, leaves aside the question of the existence of a European "people" (or demos) capable of making the requisite constitutional delegation. See infra Part IV. The better view is that both a demos and an explicit constitutional decision would be required to confer full democratic sovereignty on European institutions, thus addressing the legitimacy concerns raised supra Parts M.A. \& II.B.

108. For a summary, including an extensive bibliography, see Weiler \& Trachtman, supra note 23.

109. See id. at 364 (referring particularly to the work of Andrew Moravcsik, whose "intergovernmental lamp post has, admirably, become a veritable searchlight."); Andrew 
domains the executives and the bureaucracies of the Member States-if not necessarily their parliaments-still play a critical role. The EC thus remains an intergovernmental entity, but one in which the prerogatives of national sovereignty have been diminished by the construction of a rule-based system of supranational power. This perspective is much more consistent with a traditional international organization and is therefore a useful empirical corrective to the constitutionalist interpretation.

There are, however, certain empirical drawbacks to the intergovernmentalist perspective as well, which relate primarily to a failure to account adequately for the degree of normative autonomy that Community institutions in fact enjoy. A counter-perspective has recently emerged, also rooted in the social sciences, that is explicitly focused on explaining policymaking autonomy at the Community level. This newer "institutionalist" approach emphasizes the EC as an example of multi-level, differentiated "governance" outside the strict confines of the nation-state, as opposed to traditional hierarchical "government" at the national level.110 From this perspective, the Community is seen as an aggregation of simultaneously competing and interdependent institutions - both national and supranational-in which the predominant form of policy coordination is through networks of technocratic experts operating in relative freedom from hierarchical control.

This line of "heterarchical" thinking, as one European legal commentator has called it, ${ }^{111}$ undoubtedly reflects better the diffusion and fragmentation of normative power in an era of administrative governance. This newer interpretation, however, "makes no claim to be a normative model."112 Rather, the approach "confines itself to noting those trends within the European administrative process which supports its general theory that hierarchical thinking within the normative confines of the nation-state is a thing of the past." 113 In some sense, this explanatory and theoretical orientation is a common feature of the social-science literature on the Community generally. The principal concern of this literature tends to be either identification of the causal variables driving supranationalism, or explanation of the intricacies of institutional cooperation and coordination among the bureaucracies of disparate states.114 In the search for a robust explanatory theory, however, social scientists tend to ignore or discount the problem of democratic legitimacy, particularly in its supranational, cultural complexity. ${ }^{115}$

Moravcsik, Preferences and Power in the European Community: A Liberal Intergovernmentalist Approach, 31 J. Common Mkt. Stud. 473 (1993).

110. See, e.g., Armstrong, supra note 17; Sand, supra note 8; Wiener, supra note 17.

111. Everson, Administering Europe?, supra note 55, at 211.

112. Id.

113. Id.

114. For an overview, see, e.g., Liesbet Hooghe \& Gary Marks, Contending Models of Governance in the European Union, in Europe's Ambiguous Unity: Conflicts and Tensions in the Post-Maastricht Era (Alan W. Cafruny \& Carl Lankowski eds., 1997).

115. See generally supra Part I.B. 
In my view, the explanatory and theoretical focus of the social-science literature risks complacency toward-and, at worst, inadvertent legitimation of - the supranational status quo, regardless of whether it is understood as the strategic use of intergovernmental negotiation by national executives or as informal consensus-building by subgovernmental technocratic networks. In either case, the manner in which supranational policymaking avoids the constraints of traditional political and legal control mechanisms on the national level remains largely unexplored, at least in normative terms.

\section{An Alternative Analytical Framework: The Community as Supranational Administrative Agency}

This article asserts that, from the standpoint of democratic legitimacy, principles of administrative law provide a superior analytical framework, both descriptively and normatively, to the various approaches just described. By administrative law, however, I do not mean simply basic procedural matters or the defense of individual rights in the administrative context, important though these dimensions of administrative law may be. I mean, rather, the broader question of how those branches of government that are in fact endowed with constitutional authority-legislative, executive, or judicial-can best control and supervise the normative power delegated to the administrative sphere in a manner most consistent with democratic values. ${ }^{116}$

Analyzing the Community in administrative terms is not new. ${ }^{117}$ In a narrow sense, there has been an ongoing effort in the Community to build a genuinely "European administrative law."118 More broadly, one European commentator, Giandomenico Majone, has gone so far as to characterize the Community as something akin to an "independent fourth branch of government"-the regulatory branch-of the Member States. ${ }^{119}$ Professor Majone argues that the problem of the democratic deficit in the Cominunity is, for the inost part, a problem of institutional design and "incentive structures" to ensure accountability in the production of supranational norms. ${ }^{120}$ The primary route to legitimacy in this scheme is through transparency and participation rights in the technocratic rulemaking process, thus largely avoiding the need for hierarchical oversight, while also demonstrating a decided preference for supranational autonomy from forms of political control. ${ }^{121}$

116. See supra Part I.A.

117. See the articles of Everson and Majone, supra note 55.

II8. Joerges \& Neyer, supra note 55, at 281; see also Jürgen Schwarze, European Administrative Law (I992); Shapiro, supra note 55, at 42.

119. Majone, Independent Fourth Branch, supra note 55. For a more detailed analysis of Professor Majone's writings, see infra notes 252-280 and accompanying text.

120. Majone, "Democratic Deficit," supra note 55, at 25.

121. See infra notes 296-299 and accompanying text. 
Professor Majone regards the Community as a kind of independent regulatory agency on the American model.122 For him, American independent agencies demonstrate that hierarchical political control is not essential to the legitimation of administrative rulemaking as long as certain other conditions-for example, "clear statutory objectives" or "oversight by specialised legislative committees"123_are satisfied. However, one could fairly criticize this approach for failing to explore more fully the extent to which these features of the American system, much more than being simply manifestations of "efficient institutional design," in fact ultimately reflect the role of Congress as the legitimating political principal in our administrative state on which even independent agencies ultimately depend. Additionally, one might further query whether Professor Majone overstates the importance of independent agencies in the American system. Much of the science-intensive regulation that he admires in the United States takes place, in fact, in executive agencies such as the EPA, operating under the hierarchical authority of the President. Needless to say, this office, like Congress, derives its legitimacy from its democratic relationship with the American people.

In contrast to Professor Majone, I would suggest that the main advantage of comparing European institutions to the American administrative model is not that it focuses our attention on the undoubted need for greater transparency and participation rights in the Community's rulemaking process. Rather, its main benefit is that it focuses our attention on the absence of democratically-legitimate, hierarchical political control over the Community's essentially administrative institutions. The character of the Community as a kind of independent regulatory agency cannot be denied; nevertheless, unlike its American counterparts, there is no ultimate political body in the Community-not the Commission, not the Parliament, and not the Member State executives acting in concert through the Council of Ministers or in intergovernmental conferencescapable of providing the hierarchical legitimation of the Community's normative output in the manner of a national legislature or executive.

In my view, the lack of a legitimate political principal at the Community level itself suggests that the EC as a whole-including its purportedly "political branches" as well as its judiciary-should be understood as a supranational administrative agency of the Member States severally, which remain the political principals in the system and the loci of democratic legitimacy. The administrative perspective further suggests that the legitimation of the Community's normative output must continue to be channeled through the constitutional structures of the Mem-

122. On Professor Majone's attraction to the American model of independent and participatory administration, see generally infra Part $V$ and, more specifically, notes 252 \& 296 and accompanying text.

123. Majone, "Democratic Deficit," supra note 55, at 27. 
ber States, like the output of any other administrative body. ${ }^{124}$ The Community's institutional legitimacy emphatically does not flow from an en masse political mobilization, globally transferring sovereignty in a constitutional sense from some hypothetical European demos, however defined. The EC phenomenon, one observer has rightly noted, "is too complex and too amorphous to be presented as emerging from a new abstract constituent power."125 Rather,

[t] he EC is a pragmatic institutional construction of loose boundaries and a diffused political identity, in which different bureaucracies and social agents handle different economic and social problems around the core project of achieving market and economic integration. This resulting perception of EC governance ... highlights problems typical of any modern polity of political control and administrative discretion. ${ }^{26}$

This overall characterization of the EC as a kind of administrative agency of the several Member States best accounts, I believe, both for the Community's undoubted participation in the exercise of sovereign power like national administrative bodies, and its lack of direct and independent legitimacy apart from lawful delegations from the Member States. ${ }^{127}$ The administrative characterization is also more consistent with the predominant role played by national executives in the intergovernmental conferences and in the Council of Ministers, as well as national and supranational technocrats in the comitology system and in the Commission, in the production of Community legal norms. In this sense, the Community is best understood as an extension of the executive-technocratic governance that has characterized the development of the modern administrative state at the national level over the course of the twentieth century. ${ }^{128}$

124. Indeed, the foundations of Community law reflect the critical role played by the Member States as mediators of Community's democratic legitimacy. Politically, the Community draws its legitimacy from, variously, the intergovernmental conferences clarged with Treaty amendment, national (generally parliamentary) ratification of the Treaty and its amendments, and the presence of the Member States' ministerial representatives in the Council. On this last element, see MacCormick, Sovereignty Now, supra note 51, at 264 (" $[T]$ he effective legislature for the Community is the Council of Ministers, whose members are identifiable only by reference to the place they hold according to state-systems of law; so Community powers of legal change and criteria of validity presuppose the validity of competences conferred by state-systems, but not themselves validated by EC law."); see also Edward, supra note 40, at 13 (noting the role of the Member States as both inside and outside the Community legal and political system).

125. Areilza, supra note 31 , at 10.

126. Id. at 2.

127. The Community has admittedly attempted to create this sort of independent and direct legitimacy through an increase in the powers of the elected European Parliament. However, for the reasons set out in Part IV, infra, this "parliamentary democratization strategy" is inadequate to the task of legitimation.

128. On the historically executive-technocratic character of the EC, see supra note 31 . Professor Weiler and others have themselves observed that, in the EC, below the intergovernmental level of treaty negotiation and the supranational level of Conmunity 
From an administrative perspective, the EC Treaty should be understood, not as a constitutional charter, but as a kind of enabling legislation adopted and revised by the unanimous consent of the Member States. Rather than think in constitutionalist terms of separation of powers at the Community level, one should think in terms of the EC's delegated legislative, executive, and adjudicative functions. Although the Treaty contains a number of directly effective provisions conferring rights on private parties-which is not uncommon in enabling legislation on the national level ${ }^{129}$ - the more important provisions of the Treaty delegate normative authority to EC institutions to formulate the rules needed to achieve the Community's mandate-most notably, the completion of the internal market. ${ }^{130}$ Paralleling the procedural variation that one finds among American agencies, the rulemaking procedures in the Community-that is, both its primary and secondary legislative procedures-also vary considerably among substantive domains. In part this is a consequence of original Treaty design, ${ }^{131}$ and in part it is due to the Council's imposition of additional requirements-the comitology system-when it further subdelegates normative power to the Commission. ${ }^{132}$

The Community's severely limited budget favors rulemaking rather than more costly forms of direct intervention. ${ }^{133}$ Indeed, the vast bulk of the Community's functions as an agency of the Member States is purely normative, in both a legislative and an adjudicative sense. ${ }^{134}$ Implementation remains primarily the responsibility of the Member States, subject

legislation, there exists an "infranational" level, one "mostly about regulatory governance and management" which is therefore ripe, presumably, for the application of administrative law principles. J.H.H. Weiler et al., European Democracy and Its Critique, 18(3) W. Eur. Pol. 4, 26 (1995). My objection to this three-level breakdowninternational, supranational, and infranational-is that it implies that only the last category of governance is administrative in character. When the EC is viewed, as this Article attempts to do, from the perspective of democratic legitimacy-that is, the perceived connection between the "people" and the possessors of normative power-all three arenas of governance im the Community share the same essentially administrative character.

129. On the doctrine of direct effect, see supra notes 343-349 and accompanying text.

130. See, e.g., EC Treaty art. 94-95 (ex arts. 100-100a).

131. By one count prior to the entry into force of the Treaty of Amsterdam, there were no fewer than twenty-one different procedures available for the adoption of legislation, including four different procedures in the field of environmental policy, excluding the possibility of resort to the legislative procedure for harmonization in completion of the internal Market under Article 95 (ex art. 100a). See Renaud Dehousse, Constitutional Reform in the European Community: Are There Alternatives to the Majoritarian Avenue?, 18(3) W. Eur. Pol. 118, 123-24 (1995) (citing Jean-Claude Piris, After Maastricht, are the Community Institutions More Efficacious, More Democratic and More Transparent?, 19 Eur. L. Rev. 449 (1994)).

132. On the comitology system, see supra note 38. For further discussion, see generally infra Part V.C, especially notes $281-282$ and accompanying text.

133. See Majone, Regulatory State, supra note 55, at 87.

134. The purely normative nature of Community power, as well as the distribution of implementation responsibility, is more reminiscent of the administrative system which 
to supervision by the Commission and an array of justiciable rights of private interests. Consequently, issues of Member State compliance and enforcement continually arise, rendering the effectiveness of Community law a perennial concern. ${ }^{135}$ Subordinate legislation in the Community is further subject to a whole range of additional procedures, centered around the comitology system, that create varying opportunities for administrative negotiation among Member States. ${ }^{136}$

Since the early 1960s, despite the evident technocratic orientation of the Community's institutions, much of the legal discourse concerning the EC has been couched not in principles of administrative law, but in the conceptual vocabulary of constitutional federalism: supremacy, direct effect, implied powers, preemption, and now subsidiarity and fundamental rights. ${ }^{137}$ In part this is due to the special role that the European Court of Justice has played in furthering European integration, particularly through its claimed power to review Member State laws under Article 234 (ex Article 177) of the EC Treaty. ${ }^{138}$ However, if one looks at the provisions for legal control of Community institutions (Article 230 (ex Article 173)), it is clear that the legal regime proceeds from an understanding of the Community as an essentially administrative institution. The four specified bases for annulment of a Community act under this article are drawn directly from French administrative law, notably the recours pour excès de pouvoir: lack of competence, infringement of an essential procedural requirement, infringement of the Treaty or of any rule of law relating to its application, and misuse of powers. ${ }^{139}$ Tellingly, in the procedures for legal control, the drafters of the original Treaty of Rome made no distinction between the Council and the Commission, on the basis that the former was legislative and the latter administrative or executive in character, as one might expect to find in a constitutional system.

prevails in Germany. See Rose-Ackerman, Controlling Environmental Policy, supra note 69 , at 8 (outlining the German administrative system).

135. For a comprehensive survey, see Francis Snyder, The Effectiveness of European Community Law: Institutions, Processes, Tools and Techniques, 56 Mod. L. Rev. 19 (1993).

136. See generally id. These procedures might be analogized to certain German procedures which give both members of the Bundestag and state government ministers (via the Bundesrat) a say in the drafting of important regulations. See Rose-Ackerman, Controlling Environmental Policy, supra note 69, at 146 n.10 .

137. For a summary, see Weiler \& Trachtman, supra note 23.

138. Article 234 (ex art. 177) allows national courts, in the context of national litigation, to refer questions of Community law to the ECJ, thus providing the European Court an important tool to review Member State laws for their conformity with Community law. Much of the resulting case law-articulating such doctrines as supremacy and direct effect-has an understandably "federalist" feel. See generally Burley \& Mattli, supra note 100. For a summary of the judicial review provisions of the EC Treaty, see supra note 99.

139. The four ouvertures, or legal bases, for a recours pour excès de pouvoir in French law are incompétence, vice de forme, violation de la loi, and détoumement de pouvvoir. See 2 Vedel \& Delvolvé, Droit Administranf 299 (12th ed. 1992). Other aspects of the ECJ's jurisdiction have their roots in French administrative law as well. Compare Article 230 (ex art. 173) of the EC Treaty, with Article R 102 of the Code des tribunaux administratifs. 
Neither institution was exempt from the same range of essentially administrative claims. ${ }^{140}$

\section{Supranational Legislation and Legitimate Political Control}

\section{A. Legislative Blockage in the Community and Integration by Adjudication}

The rule of unanimous voting in the Council of Ministers during the first three decades of the Community's existence (1957-1986) meant that the executive of each Member State possessed an effective veto power over the Community's legislative output. ${ }^{141}$ Thus, at the supranational level, unanimity served as the functional equivalent of strict governmental control over administrative norm-production, precisely as one often finds in parliamentary systems at the national level. As Americans well understand, however, stringent procedural requirements-and certainly unanimity qualifies as such-can also lead to an "ossification of rulemaking" in an administrative regime, and Europeans used a similar termEurosclerosis-to describe the difficulties of political coordination in their formal legislative processes under the unanimity rule.

As a consequence of the legislative blockage in the 1960s and 1970s, the EC did what American administrative agencies have often done in the face of difficult procedural hurdles: It proceeded by adjudication. That is, the EC relied on its adjudicative authority to give content, on a case-by-

140. For more on the French influence, see Nial Fennelly, Legal Interpretation at the European Court of Justice, 20 Fordham Int'l L.J. 656, 658 (1997) ("[T] he framing of administrative remedies in the Treaties reflects both the form and grounds for such remedies in French law." (citing Opinion of Advocate General Lagrange, Case 3/54, Associazone Industrie Siderurgiche Italiane v. High Authority of the European Coal and Steel Community, [1954-1956] E.C.R. 63, 75)); see also La Communauté Européenne du charbon et de l'acier, Rapport de la délégation française sur le Traité et la Convention signés à Paris le 18 Avril 1951 (Ministre des affaires étrangères, Oct. 1951).

141. The original Treaty of Rome actually provided for a three-phase, twelve-year transitional period from 1958 through 1969. It was only during the first two phases (from the beginning of 1958 to the end of 1965) that the Treaty provided that most Council decisions would be taken on the basis of a unanimous vote. At the beginning of the third stage on January 1, 1966, the Treaty broadly expanded the areas subject to majority voting in the Council. In mid-1965, however, France, led by Charles de Gaulle, precipitated a crisis by announcing its refusal to accept the impending shift to majority voting, boycotting all meetings of the Council, in a policy known as the chaise vide, or "empty chair." The crisis was not resolved until January 1966, in what came to be called the Luxembourg Compromise, whereby one Member State could demand a Council decision by unanimity when it believed that "a very important national imterest" was at stake. Bulletin of the European Communities 8-10 (March 1966). Although the Luxembourg Compromise was in principal non-binding, a "Veto Culture" emerged, characterized by a "working assumption ... that since any country could mvoke the Compromise at any time, there was little point in pressing a proposal whenever strong objections were raised by one of the Member States." Anthony L. Teasdale, The Life and Death of the Luxembourg Compromise, 31 J. Common Mkt. Studies 567, 570 (1993). 
case basis, to the common market norms set forth in the Treaty. ${ }^{142}$ Integration by way of adjudication was less a strategic choice on the part of political actors than a move by the ECJ to fill the policy breach. "[I]mportant political outcomes [were] debated and decided in the language and logic of law," 143 particularly in the context of preliminary references under then-Article 177 (now Article 234). National courts made such references in the context of litigation, seeking interpretative statements on the scope of Community law and its impact on national norms. Despite the fact that national courts retained ultimate decisional power in a formal sense, often ECJ interpretations under the preliminary reference procedure effectively mandated a particular decision significantly constraining the effect of the Member State law in question. Through preliminary references the ECJ forged links with an array of "subnational actors-private litigants, their lawyers, and lower national courts"144creating a body of law as well as a professional community (including professors of European law) invested in the success of the Community project.

The ECJ's method of treaty and legislative interpretation throughout this period was quite open-ended, intended to extend aggressively the reach of Community competence. That extension was in large measure accomplished through recourse to the so-called "teleological method of interpretation" common in the civil law tradition, which gave the judges of the ECJ wide latitude "to justify its decisions in light of the common interests of the members as enshrined in both specific and general objectives of the original Rome treaty."145 Teleological interpretation permitted the Court "to rationalize everything from direct effect to the preemption of member state negotiating power in external affairs in every case in which the treaty grants internal competence to community authorities."146 The Court justified these doctrines "not on the basis of specific provisions in the treaty or community secondary legislation but on the accomplishment of the most elementary goals set forth in the Preamble of the treaty." 147 The ECJ gave itself maximum leeway in the pursuit of these ends through the doctrine of supremacy, whereby the Court estab-

142. See Joseph Weiler, The Community System: The Dual Character of Supranationalism, 1 Y.B. of Eur. L. 267, 271 (1981). This article argues for a distinction between "normative" and "decisional" supranationalism.

143. Burley \& Mattli, supra note 100, at 44; see also Karen Alter, The European Court's Political Power, 19 W. Eur. Pol. 458 (1996) (discussing the emergence of the European Court as the most powerful political imstitution in the European Union).

144. Burley \& Mattli, supra note 100, at 58.

145. Id. at 68 ; see also Fennelly, supra note 140 , at $664-79$. For further discussion, see infra Part VI.B.

146. Burley \& Mattli, supra note 100 , at 68 (citing Case 22/70, Commission v. Council, 1971 E.C.R. 363). For an early view by a judge on the ECJ, see Pierre Pescatore, The Law of Integration: Emergence of a New Plienomenon in International Relations, Based on the Experience of the European Communities 41-44, 86-90 (1974).

147. Burley \& Mattli, supra note 100 , at 68 . 
lished itself as the ultimate judge of the extent of Community

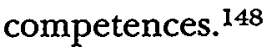

Integration by adjudication was effective in part because it appealed to rule of law sentiments among Member State officials, even where they were otherwise hostile to specific decisions. ${ }^{149}$ It gave integration a distinctly incremental feel, not necessarily a bad thing while the new regulatory regime was trying to legitimate itself. ${ }^{150}$ Incrementalism still had a profound effect on the content of national law, however. In the area of free movement of goods guaranteed by Article 28 (ex Article 30), for example, the European Court took a maximalist approach, holding that a showing of potential and indirect hindrance to interstate trade was sufficient to strike down a Member State requirement. ${ }^{151}$ A whole range of national product safety and consumer protection rules, indistinctly applicable to goods on the market but with potential impact on trade, came under challenge. In response, the ECJ developed the principle of "mutual recognition," whereby a Member State could not generally prohibit

148. As Joseph Weiler has noted, see Transformation, supra note 31, at 2414-15 \& n.26, the ECJ has never addressed its exclusive jurisdiction squarely, but imphicit in its decisions is the understanding that the Court has, as a matter of Community law, the ultimate say on the reach of Community competence. See, e.g., Case 314/85, Foto Frost v. Hauptzollamt Lübeck-Ost, 1987 E.C.R. 4199 (case in which the Court reserved to itself the sole prerogative of declaring Community law invalid); Case 66/80, SPA Int'l Chemical Corp. v. Amministrazione delle Finanze dello Stato, 1981 E.C.R. 1191 (same). For further discussion of the ECJ's so-called Kompetenz-Kompetenz, see infra Part VII.

149. See Burley \& Mattli, supra note 100, at 68 (citing Hjalte Rasmussen, On the Law and Policy of the European Court of Justice 275-81 (1986)) (" $[E]$ ven governments overtly hostile to the Court's authority [did] not seek to ask the Court to overturn a previous ruling but rather accept[ed] that ruling as a statement of law and use[d] it as a point of departure for making arguments in subsequent cases."). Weiler explains Member State deference to ECJ rulimgs in terms of "the deep-seated legitimacy that derives from the mythical neutrality and religious-like authority with which we invest our supreme courts." Weiler, Transformation, supra note 31 , at 2428.

150. A comparison with the history of American federal regulatory institutions may be helpful. Recall that when the Supreme Court finally abandoned its narrow reading of federal power to regulate interstate commerce in NLRB v. Jones \& Laughlin Steel Corp., 301 U.S. 1 (1937), it was in connection with an agency that is as "judicial" as they come. The NLRB, until relatively recently, almost never made rules. Ratlier, it used a commonlaw method of precedent more reminiscent of nineteenth-century practice, which perhaps made the transition to a federal regulatory state less threatening. (I am grateful to Peter Strauss for this insight.) Indeed, it was not until nearly three decades later that there was the explosion in rulemaking we associate with the inodern American regulatory state. See Strauss, From Expertise to Pohtics, supra note 63, at 755-56 nn.33-34 and accompanying text (referring to the "tremendous expansion ... in the prominence, use and development of rulemaking" in the United States in the 1960s). Ironically, approximately the same thirty-year interval elapsed in Europe before the explosion in rulemaking at the supranational level, from the adoption of the Treaty of Rome in 1957 to the adoption of the Single European Act in 1986. See infra notes 159-161 and accompanying text.

151. See Case 8/74, Procureur du Roi v. Dassonville, 1974 E.C.R. 837, 852. 
the circulation of goods lawfully introduced into commerce in another Member State. ${ }^{152}$

\section{B. The Advent of Autonomous Lawmaking at the Community Level}

In the 1970s, Community legislation also quietly extended, with EGJ approval, the reach of Community competences, effectively breaking down the limits on delegated powers set forth in the Treaty. The EGJ broadly interpreted, for example, the Council's legislative competence in the area of free movement of workers under the old Article 48 (now article 39) to reach qualifications for educational grants, even though at the time educational policy was clearly outside Community jurisdiction. ${ }^{153}$ The Commission and the Council also stretched the limits of the Community's purportedly "limited powers" in another fashion: through recourse to the Community's "necessary and proper" clause, then-Article 235 (now Article 308). ${ }^{154}$ Through the use of Article 235, the original limits on the Community's delegated powers were rendered effectively meaningless, and the EG adopted rules in such areas as environmental policy and consumer protection long before these areas were explicitly added to Community jurisdiction. ${ }^{155}$ The only thing holding the Community back, at least prior to 1986, was unanimous voting in the Council. The Member States could tolerate "functional spill-over" into the national domain because their executives maintained effective control over the legislative output. ${ }^{156}$

152. See, e.g., Case 120/78, Rewe-Zentral AG v. Bundesmonopolverwaltung für Branntwein, 1979 E.C.R. 649, 649-50 [hereinafter Cassis de Dijon] (holding that Germany could not prohibit the sale of beverages from another Member State containing a lower alcohol content than required by German law).

153. See Case 9/74, Casagrande v. Landeshaupstadt München, 1974 E.C.R. 773, 777-78. For a discussion, see Weiler, Transformation, supra note 31, at 2438-41.

154. Article 308 (ex art. 235) of the EC Treaty provides:

If action by the Community should prove necessary to attain, in the course of the operation of the common market, one of the objectives of the Community and this Treaty has not provided the necessary powers, the Council shall, acting unanimously on a proposal from the Commission and after consulting the European Parhiament, take the appropriate measures.

155. One might say that the way in which Article 235 was interpreted had the distinct feel of the enabling legislation of Gary Lawson's hypothetical "Goodness and Niceness Commission," empowered "to promulgate rules for the promotion of goodness and niceness in all areas within the power of Congress under the Constitution." Gary Lawson, The Rise and Rise of the Administrative State, 107 Harv. L. Rev. 1231, 1239 (1994). In Lawson's view, "[t]he United States Code is filled with statutes that create hittle Goodness and Niceness Commissions," although, in contrast to Europe, they have limited substantive domains (e.g., "securities, broadcast licenses, or ([Lawson's] personal favorite) imported tea"). Id. at 1240. In view of the ECJ's interpretation of Article 235, the EC may have become a super-"Goodness and Niceness Commission," cutting across particular substantive domains.

156. Functional spill-over describes the phenomenon whereby "any integrative action in one sector creates a situation in which the original goal can be assured only by taking actions in related sectors, which in turn create a further condition and a need for more 
This Article 235 legislation in part reflected the enthusiasm for social regulation that also prevailed in the United States in the 1970s, but one might offer a public-choice explanation as well: Such rules could be adopted at little political cost, given that the delegated legislation affected diffuse interests, whereas changes in technical rules relating to specific products might offend organized constituencies whose opposition could be politically troublesome. Formally speaking, therefore, the vast majority of technical non-tariff barriers remained on the Member States' books. In addition, one might argue that the difficult policy questions were increasingly delegated to the European level because this would allow the executives of the Member States to escape blame for decisions "made in Brussels." ${ }^{157}$ Moreover, because the Member States maintained exclusive control over implementation, it was possible for them to support the adoption of legislation at the European level that they had no intention of applying at the national level with any great rigor, if at all. ${ }^{158}$

In 1986, however, tired of "Eurosclerosis" and embarrassed about the lack of progress toward the internal market, the Member States summoned the will to adopt the Single European Act (SEA) along with the so-called "1992 Program" outlined in the Commission's White Paper Completing the Internal Market. ${ }^{159}$ Rather than force costly harmonization of standards in order to achieve the single market by 1992, the Community followed the ECJ's lead and adopted a "new approach to technical harmonization" based on the mutual recoguition principle and minimal harmonization. ${ }^{160}$ Additionally, and most importantly for our purposes, the SEA instituted a qualified-majority voting procedure in the Council for harmonization measures meant to eliminate non-tariff barriers to trade. ${ }^{161}$ It was viewed as a "low-key technical necessity in realizing the 'noncontroversial' objectives of the White Paper." 162

action, and so forth." Burley \& Mattli, supra note 100, at 55 (citing Leon Lindberg, The Political Dynamics of the European Economic Integration 384 (1963)).

157. Deliousse, supra note 131, at 120.

158. See Majone, Regulatory State, supra note 55, at 86 (criticizing this argument).

159. See Completing the Internal Market: White Paper from the Commission to the European Council, COM(85) 310 final at 9-16.

160. Article $100 \mathrm{~b}(1)$ of the EEC Treaty, as amended by the Single European Act of 1986, read:

During 1992, the Commission shall, together with each Member State, draw up an inventory of national laws, regulations and administrative provisions which fall under Article 100a and which have not been harmonized pursuant to that article. The Council, acting in accordance with the provisions of Article 100a, may decide that the provisions in force in a Member State must be recognized as being equivalent to those applied by another Member State.

161. See EC Treaty art. 95 (ex art. 100a).

162. Weiler, Transformation, supra note 31 , at 2458 . The vote-weighting system, set out in Article 205 (ex Article 148) of the EC Treaty, is complex, but the bottom line is that to defeat a measure it now takes an alliance of at least three of the large states (France, Germany, Italy, Spain, or the UK), or eight of the smallest states, or a range of possible coalitions in between. 
Qualified-majority voting, however, raised the very real prospect that the Community could adopt a piece of legislation, such as a directive, over the objections of any one Member State. Yet this was a risk that the Member States were willing to take in order to restore some semblance of political control to the integration process. Minimal harmonization, when combined with qualified-majority voting,

was better than the alternative of letting the judicial process continue to make the necessary policy choices incrementally .... . In other words, Member States were led to prefer political legislation, even at the risk of being pushed into the minority on a vote concluding Council deliberations among the Member States, to a kind of "creeping legislation" through the judicial process, to which they were completely external. ${ }^{163}$

The Treaty on European Union of 1992 extended the reach of qualifiedmajority voting. It also instituted the parliamentary co-decision procedure requiring consent of the European Parliament to legislate in those domains where the procedure applied, further diluting the capacity of Member State governments to control the legislative outcome. ${ }^{164}$

Qualified-majority voting greatly enhanced the autonomy of Community organs-particularly the Commission-and therefore the Community's permanent bureaucracy in Brussels. In principal-agent terms, the post-1986 environment significantly increased the risk of what economists call "agency losses"; that is, the freedom of the agent to pursue its own policy preferences rather than those of the principal. ${ }^{165}$ In many respects, the advent of qualified majority voting in the Council marked the beginning of true supranationalism in the Community ${ }^{166}$; its exercise of legislative power-that is, its rulemaking, broadly definedwas freed from the requirement of formal approbation by the democratically-accountable executives in each Member State, as supranational adjudicative power had long been.

However, there was a corresponding, and quite obvious, imbalance in democratic legitimacy, because the Community standing alone was unable to make a serious claim to anything except a legitimacy of the most embryonic sort, generally via the European Parliament. ${ }^{167}$ By contrast, the executives of the Member States, whatever the flaws of the parliamentary systems that produced them, could still claim legitimacy via responsibility before the national electorate in some reasonably direct sense.

163. Lenaerts, Interaction, supra note 102 , at 110-11.

164. The Treaty of Amsterdam will extend qualified-majority voting and parliamentary co-decision even further. For a summary, see Philippe Manin, The Treaty of Amsterdam, 4 Colum. J. Eur. L. 1 (1998); Petite, supra note 98.

165. See Pollack, supra note 3, at 108 (citing Roderick D. Kiewiet \& Matthew D. McCubbins, The Logic of Delegation: Congressional Parties and the Appropriation Process 5 (I99I)).

166. See Weiler, Transformation, supra note 31, at 2461-64.

167. On the problematic nature of the legitimacy derived from the European Parliament, see infra Part IV. 
Decisionmaking based on a rough consensus among the Member State executives in the Council, which qualified-majority voting now enabled, would henceforth provide at best an indirect source of political legitimacy for the Community's normative output. ${ }^{168}$

\section{Defining the Sphere of Continuing National Control}

After 1986, two forms of sovereignty were thus brought into potential conflict on a legislative level: on the one hand, the relatively autonomous, "pooled" sovereignty of the Community qua agency exercising delegated authority; and on the other, the democratically-legitimate sovereignty expressed through the political and legal institutions of the Member States. As the Member States negotiated "ever closer union" in the early 1990s-resulting in the Treaty on European Union of 1992they began to recognize the necessity of developing legal means to regulate more effectively the boundary between these two forms of sovereignty. ${ }^{169}$ Two aspects of the TEU specifically addressed this issue: the subsidiarity principle and the pillar structure. More recently, the Treaty of Amsterdam of 1997 introduced a third innovation: the variable geometry in Community law, reflected particularly in the provisions permitting "closer cooperation" among certain Member States.

1. Subsidiarity. - The insertion of the subsidiarity principle into the EC Treaty in 1992 should be viewed as an indirect effort to preserve the scope of national political control over legislative norm production. Article 5 (ex Article 3b) provides that any action falling within the concurrent competence of the Community and the Member States ${ }^{170}$ should only be taken by the EC "if and in so far as the objectives of the proposed action cannot be sufficiently achieved by the Member States and can therefore, by reason of the scale or effects of the proposed action, be better achieved by the Community."171

By its terms, Article 5 (ex Article 3b) invites a functionalist approach to the question of subsidiarity, rather than one rooted in democratic le-

168. See Sauter, supra note 7, at 34 n.22 (citing Joseph H.H. Weiler, Problems of Legitimacy in Post 1992 Europe, 46 Aussenwirtschaft 411, 421 (1991)).

169. Excluded from the discussion at this point is "comitology," or the system of committees used to maintain continuing national control over technocratic rulemaking in the Commission. Although clearly relevant to the question of national control, this paper treats it, infra Part $\mathrm{V}$, as part of the discussion of participation and transparency rights at the technocratic level.

170. Such is the case, for example, in consumer product safety or the environment, as opposed to agriculture, where the Community has exclusive competence.

171. EG Treaty art. 5 (ex art. 3b). The introduction of the concept of subsidiarity in a general way into the EC Treaty in 1992 generated a considerable amount of scholarly commentary. See generally Bermann, Tahing Subsidiarity Seriously, supra note 48 , for a survey of the literature. In light of the abundant scholarly output on the subject, Joseph Weiler lias written of "that growth industry, Academic Subsidiarity commentary." J.H.H. Weiler, Journey to an Unknown Destination: A Retrospective and Prospective of the European Court of Justice in the Arena of Political Integration, 31 J. Common Mkt. Stud. 417, 437 (1993). 
gitimacy concerns. ${ }^{172}$ However, as George Bermann has noted, although "[s]ubsidiarity expresses a preference for governance at the most local level,"173 the aim of subsidiarity is not localism per se but the pursuit of more fundamental values to which localism is linked. These include, notably, "self-determination and accountability"174 and "preservation of identities," 175 two key ingredients to democratic legitimacy, which receive their institutional expression in national political hierarchies. A functionalist approach, in my view, is clearly inadequate to understanding the full import of the subsidiarity principle. ${ }^{176}$ The subsidiarity principle has, in fact, proven to be an imperfect means of enhancing legitimacy precisely because of its mechanistic, functionalist application by Community institutions since its insertion into the Treaty in 1992. ${ }^{177}$

2. The Pillar Structure. - The second aspect of the TEU that sought to regulate the boundary between Community and Member State competence is the so-called "pillar structure" of the European Union. Under the institutional umbrella of the newly-established EU, the functions of economic and social regulation continued to fall within the competence of the macro-institutions of the EC (the "first pillar"). Expressly excluded, however, from Community competence, and therefore from Community legislative procedures as well as judicial review by the ECJ, was Member State cooperation in a common foreign and security policy (the "second pillar") as well as justice and home affairs (the "third pillar"), both of which remained subject to essentially intergovernmental control. ${ }^{178}$ This pillar structure was an implicit recognition that only the

172. See infra notes $440-448$ and accompanying text. For a critique of the functionalist orientation of the subsidiarity principle, see Paul D. Marquardt, Subsidiarity and Sovereignty in the European Union; 18 Fordham Int'l L.J. 616 (1994) [hereinafter Marquardt, Subsidiarity].

173. Berunann, Taking Subsidiarity Seriously, supra note 48, at 339.

174. Id. at 340 . According to Bermann,

Individuals are generally thought to have greater opportunity to shape the rules governing their personal and business affairs when those rules are made at levels of government at which they are more effectively represented. The opportunity to participate increases the likelihood that the law and policy that result will reflect the interests of the population concerned .... [S] elf-determimation advances essentially democratic values.

Id.

175. Id. at 341 . For example,

One result of organizing power in ways that promote self-determination and responsiveness is that local populations can better preserve their sense of social and cultural identity. The law is of course not the only or even the main determimant of identity, but it can be an important instrument in strengthening or diluting the specificity of a community's distinctive combination of forms and values.

Id.

176. I take up this argument in greater detail in connection with the discussion of Treaty interpretation and democratic legitimacy in Part VI.

177. See infra Part VI.C.2-3, especially infra notes $440-453$ and accompanying text. 178. See TEU art. 46 (ex art. L). 
Member States may legitimately exercise the most important attribute of sovereignty-physical coercion - whether externally or internally.

Admittedly, the Treaty of Amsterdam of 1997 transfers to the Community extensive competence over matters previously falling under the third pillar, such as border control, asylum, and immigration. ${ }^{179}$ During a transition period of five years, however, the Member States share the right to initiate legislation in this area with the Commission, and the Council may only adopt such legislation on the basis of unanimity. After the transition period lapses, though, the power of legislative initiative devolves to the Commission and, upon a unanimous vote in the Council, voting in the Council will henceforth be by qualified majority, subject to the parliamentary co-decision procedure of Article 251 (ex Article 189b) of the EC Treaty. In short, the Treaty of Amsterdam provides a mechanism for the ultimate transfer of legislative power on most third pillar questions to the relatively autonomous supranational institutions of the EC.

3. "Variable Geometry" and "Closer Cooperation." - As one observer notes, however, this transfer of third pillar competences "in such broad and sensitive areas [would be] virtually impossible to achieve without permitting opposing states to derogate" from new Community legislation. ${ }^{180}$ Both the United Kingdom and Ireland, for example, secured derogation rights from legislation relating to border controls. ${ }^{181}$ These sorts of rights-the clearest manifestation of the emergent variable geometry in Community law-are modeled on similar opt-out rights granted in 1992 both to the UK (on the so-called "Protocol and Agreement on Social Policy"182 as well as European Monetary Union (EMU)) $)^{183}$ and to Denmark (also on the EMU). ${ }^{184}$ This breakdown in the traditional principle that

179. See EC Treaty arts. $61-68$ (ex arts. $73 i-73 p$ ). The date of the Treaty of Amsterdam's entry into force is May 1, 1999.

180. Manin, supra note 164, at $5,19$.

181. Treaty of Amsterdam, Protocol on the application of certain aspects of Article 7a of the Treaty establishing the European Community to the United Kingdom and to Ireland, 1997 O.J. (C 340) 97. For those countries that did not secure derogation rights, the implications for national sovereignty are significant. The French Constitutional Council held that the passage in these areas of legislation by Commission initiative, qualified-majority voting, and the co-decision procedure would constrain the exercise of national sovereignty by France and that there was no prior delegation of sovereign power to the Conmunity (notably in connection with the TEU in 1992) justifying this exercise of supranational legislative power. Cons. const. no. 97-394 DC, 31 déc. 1997, Rec. 344. Consequently, without a revision to the French constitution authorizing a transfer of additional sovereign powers in this domain, the challenged provisions of the Treaty of Amsterdam could not be put into effect in France.

182. 1992 O.J. (C 224) 126, 127.

183. TEU, Protocol on certain provisions relating to the Umited Kingdom of Great Britain and Northern Ireland, 1992 O.J. (C 224) 123.

184. TEU, Protocol on certain provisions relating to Denmark, 1992 O.J. (C 224) 125. 
Community law should be applied uniformly ${ }^{185}$ suggests the inadequacy of the constitutionalist vision of the EC as a unitary, self-legitimating polity. ${ }^{186}$ While Member States may pragmatically choose to transfer certain competences to the Community, the right to opt out demonstrates that national political structures remain the presumptive expression of democratically-legitimate sovereignty.

Other provisions of the Treaty of Amsterdam, contemplating closer cooperation among subgroups of Member States, will further reshape Community law according to the new variable geometry. ${ }^{187}$ The closer cooperation provisions envision that some but not all Member States-at least a majority-may at some point desire to use Community institutions to go "further" and "faster" in matters of integration. 188 The interested Member States must first receive the authorization of the Council before proceeding to closer cooperation, acting on a proposal of the Commission and in consultation with the European Parliament. ${ }^{189}$ The Treaty does not specify the legislative domains that are amenable to closer cooperation, but does lay down certain substantive criteria: closer cooperation must be aimed at furthering the objectives of the Community; may only be used as a last resort; and may not result in discrimination or affect Community policies, actions, or programs. ${ }^{190}$ The Treaty also creates a major procedural safegnard: Each Member State retains the effective right to veto requests for any such authorization. ${ }^{191}$

185. See Manin, supra note 164 , at 18 . The only exception previously was the granting of derogation rights to new Member States during periods of transition following their accession.

186. Moravcsik \& Nicolaĩdis, supra note 24 , at 16 .

187. For an historical overview and legal analysis of the closer cooperation provisions, see Claus Dieter Ehlermann, Differentiation, Flexibility, Closer Co-Operation: The New Provisions of the Amsterdam Treaty, 4 Eur. L.J. 246 (1998); see also Giorgio Gaja, How Flexible is Flexibility under the Amsterdam Treaty?, 35 Common Mkt. L. Rev. 855 (1998); Helmut Kortenberg, Closer Cooperation in the Treaty of Amsterdam, 35 Common Mkt. L. Rev. 833 (1998); Shaw, supra note 36, at 69-81.

188. See TEU art. 40 (ex. art. K12), arts. $43-45$ (ex arts. K15-K.17), and EC Treaty art. 11 (ex. art. 5a), added by the Treaty of Amsterdam.

189. If the cooperation falls under the third pillar, the proposal must come froin the Member States, with the Commission given a right to give an opinion. In third pillar matters, the Parliament is given no role. TEU art. 40(2) (eX art. K 12(2)); see also Manin, supra note 164 , at 21.

190. TEU art. 43(1) (b)-(a) (ex art. K 15(1)(b)-(g)); see also Ehlermann, supra note 187, at 253-54.

191. Any Member State may oppose authorization for "important and stated reasons of national policy." TEU art. 40(2) (ex art. K.12(2)); EC Treaty art. 11(2) (ex art. 5 (a) (2)). In such circumstances, the matter inay be referred to the heads of state or government of the Member States, which may authorize closer cooperation only by a unanimous vote. 


\section{The Likelihood of Intensified Disputes over the Relative Legislative Competences of the Community and the Member States}

It is unclear how precisely the closer cooperation provisions are supposed to mesh - both legally and practically — with qualified-majority voting in the Council. Can a qualified majority of Member States impose its will on the minority if the majority in the end retains the option to go it alone? Although that right may exist legally, ${ }^{192}$ politically such a course would clearly call into question the legitimacy of the resulting norms in dissenting states. Viewed in the most positive light, the provisions for closer cooperation simply mean that integration will no longer proceed at a pace determined by the most reluctant Member States. Viewed more negatively, the cooperation provisions allow Member States to pick and choose the domains in which they are willing to accept the most advanced elements of Community legislation. In other words, they create a kind of general right to opt out. ${ }^{193}$

The right to derogate from a particular legislative program inevitably casts doubt on the relative scope of the Community's general legislative competence-from which a Member State may not, in theory, opt outcompared to its more specific competence under the closer cooperation provisions-from which certain Member States have, by definition, chosen not to participate. The evolving variable geometry in Community law may simply lay the groundwork for further highly contentious legal disputes over perhaps the most sensitive issue in Community law: the line between national and supranational competence. ${ }^{194}$

\section{Supranational Democratization Versus Democratic Legitimacy}

\section{A. Overcoming the "Democratic Deficit": The Parliamentary Democratization Strategy}

Since 1986, when the Single European Act eliminated unanimous voting in the Council for many of the most important legislative domains, ${ }^{195}$ the Community has needed alternative means to legitimize its

192. Closer cooperation presumes that the normal legislative procedures of the Community have been tried first. TEU art. 43(1) (c) (ex art. K.15(1)(c)).

193. The impact that this right will have on Community legitimacy is an open question. See Shaw, supra note 36, at 85 (arguing that the closer cooperation provisions "as currently conceived are little related to the core issues of legitimacy in the EC/EU context," and viewing them instead as "the product of a balancing exercise between centrifugal and centripetal political tendencies operating through the various Member States and EC/EU institutions"). Shaw's analysis arguably ignores a key aspect of the closer cooperation provisions. It is precisely because they augment the bargaining position of reluctant Member States in the legislative process of the Community that they reflect, if not the actual reality, at least the desire to recreate a semblance of legitimate hierarchical control, while also allowing the core project of legal integration to proceed. In this sense, they are best understood from the administrative perspective.

194. See generally infra Part VI.D (discussing Case C-84/94, United Kingdom v. Council, 1996 E.C.R. I-5755, 3 C.M.L.R. 671 (1996) [hereinafter Working Time Directive]).

195. EEC Treaty art. 100a. 
normative output apart from the hierarchical control of each Member State executive. Subsidiarity, the pillar structure, and variable geometry each offer indirect solutions to the question of democratic legitimacy by attempting to define the scope of Community competence in a way that both acknowledges the legitimate prerogatives of national sovereignty but nevertheless allows integration to proceed. ${ }^{196}$

None of these legal innovations, however, addresses how the Community should resolve the infamous democratic deficit-that is, how it can best legitimize the rulemaking that clearly falls within the Community's legislative competence. The official strategy here has centered on a further increase in the role of the Community's elected body, the European Parliament-in effect, to make it the legitimate, hierarchical political superior in the Community system. According to the European Court of Justice, the growing importance of the Parliament is an expression of "the fundamental democratic principle that the peoples should take part in the exercise of power through the intermediary of a representative assembly." 197

The powers and prerogatives of the European Parliament have indeed grown markedly over the course of the Community's history. Composed originally of representatives of national legislatures, the Parliament's political and legislative powers under the original Treaty of Rome were feeble. ${ }^{198}$ In 1977, however, the Parliament gained a junior role in approving the Community budget. In 1979, the first direct popular elections of members took place. In 1986, the Single European Act broadened the Parliament's legislative powers by establishing the "cooperation procedure," which constitutes a sort of suspensive veto. ${ }^{199}$ In 1992, the Treaty on European Union added the "co-decision procedure" - a true veto, in effect-generally for legislation in completion of the internal market. ${ }^{200}$ The TEU also explicitly recognized the standing of the Parliament to maintain an action against other Community institu-

196. The same could be said of the so-called comitology system, which governs the Commission's exercise of normative power delegated by the Council. See infra notes 281-284 and accompanying text.

197. Case 138/79, SA Roquette Frères v. Council, 1980 E.C.R. 3333, 3360 para. 33.

198. The original Article 137 referred vaguely to "advisory and supervisory powers which are conferred upon [the Parliament] by this Treaty." A closer look at the Treaty, however, revealed at best the right to be "consulted" in certain legislative fields, as well as the riglt of censure against the Commission as a whole.

199. Codified as EC Treaty art. 252 (ex art. 189c). Under this procedure, if the European Parliament rejects proposed legislation voted by the Council (acting by qualified majority), the Council inay still pass the legislation, but only by a unanimous vote.

200. Codified as EC Treaty art. 251 (ex art. 189b). Under this procedure, the rejection of proposed legislation approved by the Council leads to the formation of an ad hoc "conciliation commission." If the Parliament rejects the revised "conciliated" legislation, the bill is definitively rejected. The Treaty of Amsterdam would significantly extend the application of the co-decision procedure. See Petite, supra note 98 , at section IV, pt. 1. 
tions to defend its institutional role in the legislative process. ${ }^{201}$ Finally, the TEU increased Parliament's political powers-previously limited to the right of censure-by giving Parliament the right to approve the Commission as a body at the beginning of its term. ${ }^{202}$ The Treaty of Amsterdam further extends the powers of the Parliament by giving it the specific right to approve the nomination of the Commission President. ${ }^{203}$ The TEU also gave Parliament the right to force, by majority vote, the submission of a legislative proposal to the Council. ${ }^{204}$

Taken together, these prerogatives smack of a nascent parliamentarism: direct election, a budgetary role, a kind of "governmental" responsibility, the right of legislative initiative and approval. The Parliament still suffers, however, from a number of oft-noted problems: effective exclusion from the real process of decision making, dominated by the Council and the Commission; an unwieldy size; disproportionate representation of smaller Member States; internal language barriers; and popular and media disinterest. ${ }^{205}$

201. EC Treaty art. 230 (ex art. 173). The TEU's revision of Article 173 codified an earlier decision of the ECJ explicitly recognizing the right in the Parliament. See Case C70/88, Parliament v. Council, 1990 E.C.R. I-2041, I C.M.L.R. 91 (1990) (the "Chernobyl" decision), overruling Case 302/87, Parhament v. Council, 1988 E.C.R. 5615 (the "Comitology" decision). For a general description, see G. Federico Mancini \& David T. Keeling, Democracy and the European Court of Justice, 57 Mod. L. Rev. 175, 180-81 (1994) (describing the ECJ's judgment in the "Chernobyl" decision, Case C-70/88, Parliament v. Council, 1990 E.C.R. I-2041, which recognized the standing of the European Parliament to maintain an Article 173 action to defend its institutional prerogatives against the Council, as a step toward "strengthening [the Community's] democratic legitimacy").

202. See EC Treaty art. 214 (ex art. 158).

203. Id.

204. See EC Treaty art. 192 (ex art. 138b).

205. See Weiler, Demos, supra note 28 , at 233-34. A breakthrough of sorts may have come, however, in the censure controversy of January 1999 (prompted by the alleged corruption of certain members of the Commission), and the collective resignation of the Commission in Marcls 1999, following the issuance of the report of the Committee of Independent Experts. See Committee of Independent Experts, First Report on Allegations regarding Fraud, Mismanagement and Nepotism in the European Comnission, March 15, 1999, <http://www.europarl.eu.mt/experts/en/default.htm> (on file with the Columbia Law Review) [hereinafter Independent Experts Report]. As one French conmientator noted soon after the resignation of the Commission, for the first time the Commission found itself politically responsible for the internal functioning of the Community bureaucracy under conditions approaching those of governmental responsibility in a classical parliamentary deniocracy. See Yves Mény, La Commission est morte . . . Vive l'Europe, Le Monde, Friday, March 19, 1999, <http://www.lemonde.fr/actu/ international/europe/combrux/990319/meny.html. This observer further noted that European institutions were, also for the first time, simultaneously the focus of the nuajor print and electronic media of each Member State, leading to a common public debate over European institutional politics unprecedented in the listory of the EC/EU. Finally, because the resignation of the Commission took place just three months before the election of a new European Parliament in June 1999, this created the possibility of an election that would focns primarily on European questions, and not on parochial concerns in the fifteen Member States, as was usually the case in all previous European elections. 
These are difficult obstacles to overcome in themselves, but the aim of this section is not to address them per se, but rather to look at a more fundamental issue. Assume, for the moment, that this array of obstacles could indeed be overcome. Assume, more importantly, that the Parliament could in fact become the true locus of legislative power in the Community, with extensive powers of oversight over the regulatory process. Could Community institutions in those circumstances become, in a sense, "self-legitimating" through their responsibility to a European Parliament with a reasonably direct relationship with the European electorate?

\section{B. The European Parliament and the "No Demos Thesis"}

Certainly a positive answer to this question would be a logical extension of the ECJ's constitutionalist vision of the Community. The question of parliamentary prerogatives, however, forces us to examine the relationship between formal democratization, democratic legitimacy, and, ultimately, national sovereignty. From the standpoint of national sovereignty, true democratization of European institutions is problematic because it breaks a link between democracy and the nation-state. In its strongest form, the nationalist critique doubts seriously whether democracy can exist at the European level at all, given the purported impossibility of a genuine European people in a national sense-a demos-in whom sovereiguty can be said to have originally resided, which was then constitutionally delegated to European institutions. Joseph Weiler has called this the "No Demos Thesis." 206

The relationship between the demos and democratic legitimacy is especially critical for our purposes: If the European Parliament lacks democratic legitimacy, in the sense that it is not exercising powers delegated to it directly by a sovereign people, a court is simply not justified in regarding it as a normal legislature. That is, the court would not be justified in giving broad deference to its findings of fact and conclusions of law in the same way and to the same extent as those of a national legislature. ${ }^{207}$ In the absence of a European demos, the Community legislative process might still be legitimate, but only in an administrative sense, in that it is exercising authority within its sphere of competence lawfully delegated by the Member States. The legislative process would be subject to judicial review, not solely for conformity with the broad requirements of the Treaty or for violation of fundamental rights as one might expect in the case of a legislature, but also for basic procedural fairness and, more importantly, substantive rationality in the same manner as any other administrative entity.

In a fundamental sense, therefore, the legal character of the European Community turns on the existence of a European demos, thus

206. See Weiler, Demos, supra note 28 , at 224-31.

207. The ECJ does in fact accord the Council and Parliament such deference. See infra notes $410,417-434$ and accompanying text. 
requiring us to examine the implications of the No Demos Thesis more closely. The basic premise of the thesis is not inherently nationalistic; indeed, it rests on an essential principle that few would dispute:

Democracy does not exist in a vacuum. It is premised on the existence of a polity with members-the demos-by whom and for whom democratic discourse with its many variants takes place. The authority and legitimacy of a majority to compel a minority exists only within political boundaries defined by a demos. ${ }^{208}$

The tough question is who properly may be said to be a member. In modern European history, to date at least, there has been a broadly perceived link between membership in an identifiable, cohesive national community and the existence of a demos, a linkage that has often given particular legitimacy to the nation-state as a democratic and sovereign unit. $^{209}$

The relationship between demos and nation is, however, delicate and susceptible to differing interpretations-some very unpleasant, indeed reprehensible. What recently raised Joseph Weiler's ire, and inspired him to bring his formidable critical and analytical powers to bear on the question, was the notion of demos implicit in the decision of the German Federal Constitutional Court in what is known as the Maastricht Decision. $^{210}$ This ruling cleared the way for German ratification of the Treaty on European Union of 1992, but its reasoning required that the Court reserve for itself, as defender of the democratic rights of the German people, the so-called Kompetenz-Kompetenz, or ultimate jurisdiction to determine the extent of Community competences relative to Germany.

This is not an objectionable position in itself. ${ }^{211}$ Professor Weiler asserts, however, that the ruling was based on a conception of an ethnically homogeneous, "organic" German demos, the democratic rights of

208. Weiler, Demos, supra note 28, at 222.

209. To demonstrate the relationship, consider a hypothetical, advanced by Professor Weiler, of an Anschluss between Germany and Denmark. Under terms of the Anschluss, Danes would be guaranteed full representation in the Bundestag. Professor Weiler argues, I think correctly, that formal democratic rights would be of little comfort to the Danes if they were condemned to permanent minority status in the legislature, a demos without a country or institutions of its own. See id. at 228. Robert Dahl has elsewlere made much the same point, using a similar example:

The criteria of the democratic process presupposes the rightfulness of the unit itself. If the unit itself is not a proper or riglitful unit, then it cannot be made rightful simply by democratic procedures. If the United States were to compel Costa Rica to become the fifty-first state, would not Costa Ricans rightly feel-and we too-that a grave injustice lrad been done?

Robert A. Dahl, Federalism and the Democratic Process, in Liberal Democracy 95, 103-04 (J. Roland Pennock \& John W. Cliapman eds., 1983).

210. BVerfGE 89, 155, translated in English at 1 C.M.L.R. 57 (1994).

211. See MacCormick, Sovereignty Now, supra note 51, at 264-65. For greater detail, see infra Part VII. 
which it was the Constitutional Court's obligation to defend. This organic notion traces its intellectual roots, he argues, to Carl Schmitt, perhaps the most influential conservative constitutional theorist in Germany at the end of the Weimar Republic and subsequently the leading legal theorist in the early years of the National Socialist regime. ${ }^{212}$ In a theoretical refinement of the Nazi ideal of a racially-pure Volksgemeinschaft, Schmitt identified social homogeneity as the prime criterion of modern democracy, thus requiring, if necessary, "the excision or destruction of the heterogeneous." 213 Professor Weiler thus understandably laments: "[O]f all the rich currents in the German national debate on polity and membership [the German Constitutional Court] had to pick up this one." 214

\section{The "Hard" and "Soft" Versions}

No one, and certainly not Joseph Weiler, argues that Schmitt's extreme racist views or his polarizing friend-enemy conception of politics were imported wholesale into the Maastricht Decision.215 Rather, in Professor Weiler's view it is a question of inspiration, couched in "the universal values of democracy." 216 The Schmittian intellectual lineage is reflected in the "hard" version of the No Demos Thesis, which holds that democracy is impossible without an ethnically homogeneous, "organic" demos-in other words, a Volk-the absence of which renders true democracy unattainable at the European level. In this version, the demos has "an almost natural connotation. You are born German the way you are born male or female .... The implication of this is that one's nationality as a form of identity is almost primordial ...., taking precedence over other forms of consciousness and membership."217

There is, of course, also a "soft" version of the No Demos Thesis. This "not yet" version does not adhere to the notion of nationality as an organic, natural condition, and thus is open to the idea that, "[a]lthough there is no [European] demos now the possibility for the future is not

212. See generally Joseph W. Bendersky, Carl Schmitt: Theorist for the Reich (1983); George Schwab, The Challenge of the Exception: An Introduction to the Political Ideas of Carl Schmitt between 1921 and 1936 (2d ed. 1989).

213. Schwab, supra note 212, at 62-63 (quoting Carl Schmitt, Die geistesgeschichtliche Lage des heutigen Parlamentarismus 14 (1926)).

214. Weiler, Demos, supra note 28, at 224.

215. Professor Weiler discusses extensively the Schmittian influences on the writings of the Juge-Rapporteur of the Maastricht Decision, Paul Kirchhof, but does not say that Kirchlof's views are identical to those of Schmitt. Professor Weiler further acknowledges that in "[c]omparing the writings of Kirchhof and the ultimate decision of the Court one gets the impression of a Court which was not altogether happy with the full-blooded views of its Rapporteur. ... The compromise seems a watered-down version of Kirchhof," which permits alternative readings. 1d. at 225. Professor Weiler hoped that his critique could provide the incentive to reject the strongly Kirchhofian interpretation.

216. Id. at 222.

217. Id. at 227. 
precluded."218 Professor Weiler, however, assimilates the two versions, soft and hard, arguing without much elaboration that they share "the same understanding of peoplehood, its characteristics and manifestations." 219 Neither version in his view permits the possibility of democratization at the European level, or, in the case of the soft version, at least not any time soon. Most importantly, Professor Weiler asserts, a European Parliament without a European demos is, from the standpoint of either position, "practically despotic," with a writ possessing "only slightly more legitimacy than the writ of an emperor."220

Is this a fair characterization? As noted previously, it is not necessary to recognize the existence of a true demos at the European level to still regard the Parliament as legitimate, at least in an administrative sense, as an elected adjunct in an essentially administrative system. The Parliament could be analogized to the municipal or departmental councils of France which, although elected, are recognized elements of France's otherwise (still) highly centralized administration. ${ }^{221}$ These councils exercise authority guaranteed both constitutionally and legislatively, subject to legal controls by the French administrative court system. ${ }^{222}$ The fact that they do not represent a demos in a national sense hardly reduces their legal and popular legitimacy, as long as they remain within the confines of their delegated legal authority. Indeed, the fact that they are elected probably augments their legitimacy in the administrative system.

Because Professor Weiler does not examine this alternative basis for legitimacy, he is forced to make-in order to protect Community rulemaking from accusations of "despotism"-a highly abstract claim for the existence of a European demos based on civic values and what he calls "critical citizenship." 223 He speaks of a demos rooted not in "transEuropean cultural affinities or shared histories" but in an abstract "commitment to the shared values of the Union as expressed in its constituent documents." ${ }^{24}$ By that he apparently means a commitment "to the duties and rights of civic society covering discrete areas of public life, a commitment to membership in a polity which privileges exactly the opposites of nationalism - those human features which transcend the differences of organic ethno-culturalism."225 Professor Weiler argues for the possibility (indeed the necessity) of overlapping national and supranational "demoi,"226 resulting from a decoupling of nationality and citizenship,

218. Id. at 229 .

219. Id. at 230 .

220. Id. at 231.

221. See generally 2 Georges Vedel \& Pierre Delvolvé, Droit administratif $474-575$

(11th ed. 1990) (in particular, Part IV, ch. III, "Les collectivités locales").

222. See id. at 567-89.

223. Weiler, Demos, supra note 28, at 256.

224. Id. at 252.

225. Id.

226. Id. at 253. 
which might then serve to legitimize Community institutions while also disciplining the excesses of nationalism.

The idea of decoupling has a definite normative appeal, but, as Professor Weiler implicitly acknowledges, he is calling for nothing less than a profound cultural change in peoples' identities: “[E]ven this construct of the European demos, like the Volkish construct, depends on a shift of consciousness. Individuals must think of themselves in this way before such a demos could have full legitimate democratic authority."227 This sounds remarkably similar, in its essentials, to the soft version of the No Demos Thesis. In contrast to the Schmittian version, the soft version regards national consciousness as an open system, path dependent to be sure, but nevertheless socially and historically malleable. In this sense, it shares much with a perfectly respectable line of sociologists, anthropologists and historians, such as, for example, Max Weber. According to the scheme set out in Economy and Society, a "political community" (Weber's term most closely approximating a demos) requires a "particular pathos" and "enduring emotional foundations" derived from a history of "common political struggle."228 Such a history of common struggle gives rise to a "'community of memories' which ... constitutes the ultimately decisive element of 'national consciousness." "229 Weber, in sharp contrast to Schmitt, is describing a political community as an historical and social construct rather than an organic-ethnic-racial reality, one purportedly pre-dating history, society, the state, or whatever. Weber even leaves open the possibility of a multi-national political community, as long as there also exists the necessary "community of memories" based on a heritage of "common political struggle." 230

Max Weber's message is hopeful but cautious. Europe must be built on more than instrumental exchange or abstract values disconnected

227. Id. at 254. I use the term "cultural" in a different sense from Joseph Weiler. I see culture as a dynamic historical construct, a continually evolving system of interpretation, see supra note 11, whereas for Professor Weiler the term connotes the "organic" conception of peoplehood. See Weiler, Demos, supra note 28, at 229 (referring to "these organic cultural-national criteria" of the hard version of the No Demos Thesis). Consequently, in my view, we should avoid endowing an analytical abstraction like "culture" with causative properties. Rather, culture evolves out of the experience of historical change by individuals. See E.P. Thompson, History and Anthropology, Lecture Given at the Indian History Congress (Dec. 30, 1976), in Making History 200, 222 (1994) [hereinafter Thompson, History and Anthropology] ( ${ }^{[}[\mathrm{H}]$ istorical change eventuates . . . because changes in productive relationships are experienced in social and cultural life, refracted in men's ideas and their values, and argued through their actions, their choices and their beliefs.").

228. In Weber's view, this emotional state is ultimately grounded, sadly, on the expectation that the individual member might die in the group interest. See 2 Max Weber, Economy and Society 902-03 (Guenther Roth \& Claus Wittich eds., \& Ephraim Fischof et al. trans., 1978).

229. Id. at 903.

230. Id. 
from historical context. ${ }^{231}$ Yet, despite the formidable social and historical obstacles to forging a European political community in a supranational sense, these obstacles are not insurmountable in a nationallyeven regionally-heterogeneous continent like Europe. The experience of the last fifty years bears this out in important respects. A genuine European consciousness may not yet have developed to the same extent or on the same terms as those of a nation-state, but a foundation has been laid for a shared European political community with a strong cohesive quality. Liberal values and a commitment to human rights, which form the bases of Professor Weiler's "critical citizenship," have a much greater and more widespread legitimacy in today's Europe than in, say, late-nineteenth or early-twentieth century Germany, precisely because there is a shared memory of struggle in this century to overcome Europe's own selfdestructiveness. ${ }^{232}$ Professor Weiler implicitly agrees: Indeed, one of his principal motivations for attacking the No Demos Thesis with such ferocity is to counteract the negative propensities of nationalism which "are a living part of the history of the European Nation-State . . . so well known as to obviate discussion." 233

\section{The Continued Pull of the Nation-State}

Despite this shared memory, however, there still exists an "existential craving for meaning and purpose" that for many is apparently only satisfied by "nation and state, with their organizing myths of fate and destiny." ${ }^{234}$ Professor Weiler acknowledges the comparatively stronger "psycho-sociological" power of national identity over supranational identity but asserts that national identity must be "properly managed and contained" via his notion of critical citizenship. ${ }^{235}$ Management and containment is possible, in his estimation, because national identity has, "at certain critical moments of transition, a far larger degree of artificiality, of social constructionism and even social engineering" than is usually sup-

231. A political community can only be said to exist "if, and in so far as, [it] constitutes more than an 'economic group'; or, in other words, in so far as it possesses value systems ordering matters other than the directly economic disposition of goods and services." Id. at 902.

232. The postwar generation of European leaders believed strongly that intensified supranational cooperation was the only viable alternative to the reckless destruction of the first half of the twentieth century; indeed, this understanding provided much of the initial emotional underpinnings for the European project. Even if not exactly a "shared" history of struggle in the sense that Weber probably meant-given that the conficts often pitted European against European - the common memory of destruction and deprivation at each other's hands certainly had, and continues to have, a positive mupact on the popular legitimacy of what is otherwise a highly bureaucratic and legalistic enterprise.

233. Weiler, Demos, supra note 28, at 248.

234. Weiler \& Trachtman, supra note 23 , at 371 .

235. Weiler, Demos, supra note 28 , at 247. 
posed. ${ }^{236}$ This has undoubtedly been true in certain contexts. ${ }^{237}$ But history also cautions us not to overestimate the capacity of elites to manipulate national feeling or casually disregard culturally-embedded modes of thought. 238

For the time being, national and supranational identities in Europe exist in a cultural tension, with national identity still holding the decisive advantage, ${ }^{239}$ although subnational, "regional" identity is increasingly strong. ${ }^{240}$ It strikes me as dangerous, in view of the continued strength of national and even regional identity, to conceive of a European demos as one not based on "trans-European cultural affinities or shared histories." ${ }^{241}$ It is only through a shared history that the normative, civilizing and liberal values that Professor Weiler seeks to promote are given a durable social existence. Professor Weiler is clearly aware of the potential

236. Id. at 239. Again, I think this reflects the fundamental similarity between Professor Weiler's concept of demos and the "soft" version.

237. In late-nineteenth century France, for example, when leaders of the Third Republic were seeking to legitimate the new regime in the eyes of the French people, history and memory were consciously merged in an official effort-via public education, monuments, and rituals- to foster respect for "Republican" values and to forge national feeling. Pierre Nora and a number of colleagues have sought to identify these lieux de mémoire, or "places of memory," that came to be seen as eunbodying or celebrating the Republican or national past. See Les lieux de mémoire (P. Nora ed., 1984) (2 volumes); see also Eugen Weber, Peasants into Frenchmen: The Modernization of Rural France 1870-I914 ch. 18 (1976).

238. The case of late-nineteenth-century Germany is the prime example, in which the old elites pursued several manipulative strategies to promote national feelimg to undergird the new imperial regime. Rather than successful manipulation by the old elites, however, historians have noted a deteriorating relationship in the 1890 s between elite and popular nationalism as the social strains of rapid industrialization and urbanization became more evident. The result was a radicalized German lower-middle class set against the prevailing imperial regime. See David Blackbourn, The Mittelstand in German Society and Pohitics, 1871-I914, 4 Soc. Hist 409 (1977); Geoff Eley, Defining Social Imperialisun: Use and Abuse of an Idea, 3 Soc. Hist. 265, 282 (1976). Professor Weiler is well aware of this history and indeed has noted parallels to the situation today, in which European institutions particularly have come to symbolize "the bureaucratization of life," "the depersonalization of the market," and the "competitive structures of mobility; rapid urbanization and centralization of power." Weiler \& Trachtman, supra note 23, at 369.

239. See generally Defleun \& Pampel, supra note 61; Shore, supra note 61; Wood, supra note 61 .

240. The Community has beneflted from the (re) emergence of regional identities, to the extent that this development has weakened the representative claims of national governments vis-à-vis the supranational level. However, the Member States also benefit insofar as they can strategically exploit a broader European identity to pacify certain regional claims (e.g. the Basques') against the national level. The Treaty on European Union attempted to institutionalize regionalism and harness its benefits through the creation of the "Committee of the Regions." EC Treaty arts. 263-265 (ex arts. 198a-198c). The Treaty requires the Committee to be consulted on matters relating to trans-European networks, public health, education, youth, culture, and economic and social cohesion. But the Committee can also take the initiative and give its opinion on other policy matters that affect cities and regions, such as agriculture and environmental protection. The Coununittee is part of a broader effort to bring the Community "closer to the citizen."

241. Weiler, Dentos, supra note 28, at 252. 
gulf that can exist between the normative articulation of values and their social and political observance. ${ }^{242} \mathrm{He}$ is equally aware, moreover, of the problems of social and political identity engendered by the process of European integration. ${ }^{243}$ And yet, one might fairly question whether Professor Weiler's constructs of multiple demoi and critical citizenship remain-at least for the moment-too normatively abstract to serve as useful responses to the social and political problem of identity in today's Europe.

I have concerns about the "the politically fractured self" that Professor Weiler is prepared to celebrate, ${ }^{244}$ particularly given its fragile cultural underpinnings in an age of significant economic dislocation resulting from globalization. ${ }^{245}$ The notion of multiple membership in overlapping demoi may in fact be an accurate reflection of the undoubted fragmentation of power and sovereignty in the modern state, of which the EC is both an agent and a consequence. ${ }^{246}$ Yet, attention must be paid to how this fragmentation is being experienced by various, particularly disadvantaged, social groups. ${ }^{247}$ In this sense, the notion of multiple political demoi may ask too much from the still largely nation-centered peoples of Europe, which may be unprepared to proceed down this cultural path, as well as from European law and institutions, which may lack the capacity to lead them. The result could be both deeper resentment and more cynicism toward "Europe" than apparently already exists.

Proponents of the soft version rightly emphasize, therefore, that for the time being evolution toward a fully-fledged European "political community" in a Weberian sense (that is, the development of a European

242. See, e.g., J.H.H. Weiler, Bread and Circus: The State of European Union, 4 Colum. J. Eur. L. 223, 231-33 (1998) [hereinafter Weiler, Bread and Circus].

243. See id. at 229-30.

244. Weiler, Dentos, supra note 27 , at 256.

245. Ernest Gellner's discussion of the intensification of perceived social divisions caused by industrialization in the nineteenth and twentieth centuries is suggestive of the sorts of cultural problems that may follow similarly painful dislocations resulting from the ongoing process of globalization. According to Gellner, such periods of dramatic economic transition engendered

very sharp and painful and conspicuous inequality, all the more painful because accompanied by great disturbance, and because those less advantageously placed, in that period, end to be not only relatively, but also absolutely miserable. In that situation ... latent political tension is acute, and beconres actual if it can seize on good symbols, good diacritical nıarks to separate ruler and ruled, privileged and underprivileged.

Characteristically, it may seize on language, on genetically transnitted traits ("racisn"), or on culture alone.

Ernest Gellner, Nations and Nationalism 73-74 (1983).

246. See MacCormick, Sovereign State, supra note 2 (discussing theoretical implications of the European Community's challenge to traditional noodes of sovereignty).

247. See Thompson, History and Anthropology, supra note 227, at 222 (outlining an analytical approach that suggests that the nuanner in which this fragmentation is experienced in social and cultural life will be critical to the future direction of historical change). 
demos) is still in its formative stages. ${ }^{248}$ ln my view, recognizing this fact simply highlights the administrative character of the EC-that is, its attenuated relationship with the sovereign and democratic "peoples" of the Member States, mediated through national constitutional structuresand thus counsels against an excessive reliance on formal democratization at the European level as the sole means of addressing the democratic deficit. Europe is left in a position that does not preclude further formal democratization of its supranational institutions via increased powers of the European Parliament, but recognizes that it must follow a pragmatic rather than an idealist approach. In other words, in the absence of a demos, we should not confuse formal democratization of European institutions with democratic legitimacy. ${ }^{249}$ The Community remains, in essence, a supranational administrative body, the legitimacy of which derives from its ability to solve practical problems reasonably efficiently, as a regulatory agency of the Member States representing their particular national communities. 250

\section{Partictpation, Transparency, and the Ideal of a Deliberative SUPRANATIONAL TECHNOCRACY}

\section{A. Technocracy and the "Pathologies" of Democratic Politics}

The absence of a demos is not the sole basis for criticism of a parliamentary democratization strategy, but it is the most fundamental. One might also question parliamentary democratization from an instrumental perspective, in at least the two following respects. First, expanding the role of the Parliament risks reproducing at the European level the perceived pathologies of party politics and the concomitant interest-group

248. Professor Weiler effectively points this out as well. See Weiler, Demos, supra note 28, at $239 \& \mathrm{n} .51$ ("For most Europeans any sense of European identity defined in organic-culture or national terms would be extremely weak."); see also Jachtenfuchs, supra note 14, at 128 ("Up until the present all attempts to find or even to promote a common European political identity have been rather unsuccessful, and such consciousness wotld only transpire after a very long period of time.").

249. See generally Marquardt, Deficit Reduction, supra note 31. This sort of confusion has characterized much of the ECJ's case law regarding the powers of the European Parliament. See, e.g., the seminal judgment in Case 138/79, SA Roquette Frères v. Council, 1980 E.C.R. 3333, 3360 para. 33 (calling the Parliamentary consultation requirement an expression of "the fundamental democratic principle that the peoples should take part in the exercise of power through the internnediary of a representative assembly"); see also Mancini \& Keeling, supra note 201, at 180-81.

250. It is perhaps because the Community's legitimacy is essentially administrative in character that the Community has been able to survive for so long without obvious democratic legitimacy of its own. Rather than demonstrating a breach between the Community's low normative legitimacy as a democratic body and its high social acceptance, see Weiler, Bread and Circus, supra note 242, at 233, 235, the Community's durability owes to a popular appreciation that its legitimacy flows from oversight by national political institutions, like other adininistrative and technocratic bodies. The problem of the democratic deficit only became pronounced in the Community when, after 1986, the autonomy of its legislative process from national control became inore apparent. 
manipulation, blockages, and policy failures that one finds in parliamentary systems at the national level. Second, parliamentary democratization largely misses the point, because the democratic deficit is really an accountability deficit at the subordinate technocratic level due to the lack of transparency and legally-enforceable participation rights in the regulatory process.

These two critiques are related but somewhat contradictory. Both reflect the view that the essence of modern governance is technocratic rather than political. The first critique implicitly assumes the superiority of technocratic decisionmaking over legislative politics on both procedural ("rational deliberation") and substantive ("sound policy") grounds. The second, by contrast, reflects a distrust of unbridled technocracy and demands significant outside participation and transparency as a means of legitimation. In some sense, the aim of the second critique is, as Susan Rose-Ackerman has put it in another context, to make "democratic values operational" in an age where technocratic governance is unavoidable. ${ }^{251}$

Perhaps the most articulate European exponent of this position is Giandomenico Majone. The development of the Community as an administrative entity reflects, in Professor Majone's view, a broader trend that he sees throughout the industrialized world-especially in Europetoward a purported American model of "administrative regnlation."252 Professor Majone defines administrative regnlation as "economic and social regulation by means of agencies operating outside the line of hierarchical control or oversight by the central administration." 253 For him, the "perceptions of mismatch between existing institutional capacities and the growing complexity of policy problems" is driving the trend. ${ }^{254}$ Complexity demands delegation to independent agencies, and especially to the supranational institutions of the EC. Traditional intergovernmental approaches are inadequate because of the collective-action problems that inevitably arise in policy coordination and compliance among formally sovereign states, as well as the danger that policy outcomes will overemphasize purely national interests. The complex nature of the problems facing Europe further mandates that supranational institutions possess "a high level of technical and administrative discretion." 255

251. Rose-Ackerman, Controlling Environmental Policy, supra note 69, at 1.

252. Majone, Regulatory State, supra note 55, at 83-84. Over the last several decades, France and Britain, for example, have increasingly abandoned centralized administrative control as the principal means of market regulation, opting instead for autorites administratives indépendantes and decentralized regulatory offices. See id. at 83.

253. Id. at 83.

254. Id. at 85. Among these problems he lists "policing financial markets in an increasingly interdependent world economy; controlling the risks of new products and new technologies; protecting the health and economic interests of consumers without mipeding the free flow of goods, services and people across national boundaries; reducing environinental pollution." Id.

255. 1d. at 89. 
Perhaps most importantly, delegation is necessary to defeat the "short-termism" of electoral politics, which undermines the credibility of regulation in the eyes of regulated interests. ${ }^{256}$ From Professor Majone's perspective, "politics" threatens "policy," because the segmentation of the democratic process "into relatively short intervals produce[s] negative effects when the problems faced by society require long-term solutions. Under the expectation of alternation [i.e., being voted out of office], politicians have few incentives to develop policies whose success, if at all, will come after the next election."257 The "pathologies of politics," 258 however, go even deeper. Politicians seeking re-election are averse to the reflective deliberation that sound policy-indeed, genuine democracy-requires. "[L]egislators engage in advertising and position taking rather than in serious policy making, or they design laws with numerous opportunities to aid particular constituencies. Thus, re-election pressures have negative consequences for the quality of legislation."259 According to Professor Majone, the problem with a parliamentary democratization strategy in Europe is that it will "compromise the effectiveness of the supranational institutions. The comparative advantage of EU regulation lies mainly in the relative insulation of Community regulators from the short-run political considerations and pressures which tend to dominate national policy-making."260

In sharp contrast, Professor Majone depicts the legislative processes of the Community in a distinctly better-perhaps idealized-light. The linchpin is the Commission, which has the exclusive right to propose legislation to the Council while also possessing significant subdelegated regulatory powers under the comitology system. ${ }^{261}$ In Professor Majone's view, the Commission forms "the central node in a vast 'issue network'

256. Majone, Temporal Consistency, supra note 55 , at 1 ; see also Majone, "Democratic Deficit," supra note $\mathbf{5 5}$, at 17.

257. Majone, "Democratic Deficit," supra note 55, at 17; see also Majone, Temporal Consistency, supra note 55 , at 1 . In reaching this conclusion, Majone relies significantly on the findings of Terry Moe in the American context. See Terry Moe, Political Institutions: The Neglected Side of the Story, 6 J.L. Econ. \& Org. 213 (1990) (Special Issue).

258. This is the phrase Susan Rose-Ackerman uses to make a similar argument in connection with legislative politics in Germany and the United States. See Rose-Ackerman, Controllimg Environmental Policy, supra note 69, at 18-36. In analyzing the dangers of parliamentary democratization in Europe, Majone cites generally Susan Rose-Ackerman, Rethinking the Progressive Agenda: The Reform of the American Regulatory State (1992), whicl makes much the same argument. See Majone, Regulatory State, supra note 53, at 94 $\mathrm{n} .36$ and accompanying text.

259. Majone, Regulatory State, supra note 55, at 94. Professor Majone's perspective on legislative politics reflects the influence of social choice theory, which "demonstrates the fundamental difficulties of making consistent policy choices under democratic conditions. It teaches that democracy may produce illogical and inconsistent results. Rational clioice models of politics counsel careful monitoring of the representative system because of the weak imcentives for citizens to become informed about political choices." Rose-Ackerman, Is Germany a Model?, supra note 68, at 1280.

260. Majone, Regulatory State, supra note 55, at 94 .

261. On comitology, see infra notes $281-282$ and accompanying text. 
that includes not only experts from the national administrations, but independent experts (also from non-EU countries), academics, public-interest advocates like environmentalists and leaders of consumer movements, representatives of economic and professional organisations, and of regional bodies." 262 Most admirable from the standpoint of rational deliberation and openness, Professor Majone asserts that "Commission officials listen to everybody," operating "less as technical experts alongside other technical experts, than as policy entrepreneurs." ${ }^{63}$ Policy entrepreneurship distinctly favors "innovative regulatory solutions," which follow "substantive rather than national lines. A good deal of copinage technocratique $e^{264}$ develops between Commission officials and national experts interested in discovering pragmatic solutions rather than defending political positions." 265

The basic premise of Professor Majone's depiction of the Community's legislative and regulatory processes is that most difficult policy questions in Europe are now of a "technical" rather than "political" nature and that the distribution of normative power at the Community level reflects this reality. Indeed, he argues that " $[\mathrm{b}] \mathrm{y}$ the time a Commission proposal reaches the political level, first in COREPER (the committee of permanent representatives of the member states) and then in the Council of Ministers, all the technical details have been worked out and modifications usually leave the essentials untouched." 266 However, Professor Majone often simply assumes a clear distinction between technical questions and politics. One might fairly ask: Has technical expertise really overtaken politics in the way that Professor Majone claims?

\section{B. "Depoliticization" and the Cultural Foundations of Technocratic Autonomy}

On one level, I would have to agree that it has. I am speaking not of objective fact but of prevailing cultural interpretations of the modern administrative state. ${ }^{267}$ Among elites, the administrative state is usually justified by an

epistemological distinction between the proper realm of politics belonging to representative institutions, and that of purportedly "non-political" expertise (scientific, economic, financial, or organizational) belonging to a separate, administrative sphere. The perceived distinction between politics and expertise is im-

262. Majone, Regulatory State, supra note 55, at 90 . One observer has placed the number of consultative bodies of the Commission at around 1300. See Areilza, supra note 31 , at 6 .

263. Majone, Regulatory State, supra note 55, at 90 (citing John W. Kingdon, Agendas, Alternatives, and Public Policies 188 (1984)).

264. This roughly translates as "technocratic comraderie."

265. Majone, Regulatory State, supra note 55, at 91-92.

266. Id. at 92. Professor Majone notes further that the advent of qualified-majority voting, as well as the parhamentary "co-operation procedure," undermine the power of the Member States to bring political considerations to bear in the legislative process. Id.

267. See Lindseth, Comparing Administrative States, supra note 73, at 590-91. 
plicit in any delegation of lawmaking authority away from representative political institutions to administrative or "expert" bodies [whether national or supranational].

The effort to create structures of government reflecting a redefined boundary between law, politics and administration was essential to the institutionalization of administrative power in the decades after the Second World War. ${ }^{268}$

But in another, more objective sense, I believe one cannot accept a distinction between politics and expertise. Although the aim of technocratic governance was (and still is) to "depoliticize" policymaking, ${ }^{269} \mathrm{I}$ would nevertheless argue that the result has been "much less a transformation of political questions into technical ones than their 'displacement' in to the administrative realm without altering their true nature."270 "The difficult questions of balancing competing interests, allocating scarce resources, and choosing among potentially contradictory values [have] continued to present themselves," 271 only now in administrative rather than political fora. Science rarely provides a complete answer to these essentially political questions, even where administrative policymakers are tempted to claim otherwise. ${ }^{272}$

The cultural underpinnings of the modern administrative state have thus permitted "experts"-or politicians citing "experts"-to advance es-

268. Id. During this period, often following the perceived example of the United States, European technocrats and their political allies sought to create an institutional space within which the purported lessons of science and expertise could be applied in relative freedom from parliamentary and party interference. For a concrete legal outcome, see Fr. Const. (1958) Tit. 5, arts. 34, 37 (defining the spheres of legislation and regulation). A judicial variation on this distinction-between "law" and "policy," or as the French would put it, between la légalité and l'opportunité-further reflected the quest for autonomy of the administrative sphere: In theory, courts were to refrain from interfering with bureaucratic policymaking unless a clear question of legality was presented. See 1 Georges Vedel \& Pierre Delvolvé, Droit administrative 529 (12th ed., 1992).

269. See Lindseth, Comparing Administrative States, supra note 73, at 591. Michel Debré, de Gaulle's first Prime Minister and a principal architect of the French Constitution of 1958, explicitly described such "depoliticization" as a "major imperative" during his speech presenting the first government of the Fifth Republic to the National Assembly in January 1959. La dépolitisation: inythe ou réalité? 51 (Georges Vedel ed., 1962) (quotes translated from French); $c$. John F. Kennedy, Remarks to Members of the White House Conference on National Economic Issues (May 21, 1962), reprinted in Public Papers of the Presidents of The United States: John F. Kennedy, Jan. 1-Dec. 31, 1962, 420-22 (1963):

The fact of the matter is that most of the problems, or at least many of them, that we now face are teclinical problenis, are administrative problems. They are very sophisticated judgments which do not lend themselves to the great sort of 'passionate movements' whicl have stirred this country so often in the past.

270. Lindseth, Comparing Administrative States, supra note 73 , at 591. The tern "displacement" is taken from Bonnie Honig, Political Theory and the Displacement of Politics (1993).

27I. Lindseth, Comparing Administrative States, supra note 73, at 591.

272. See generally Wendy E. Wagner, The Science Charade in Toxic Risk Regulation, 95 Colum. L. Rev. 1613 (1995). 
sentially political positions by recasting them as technical matters outside of politics. ${ }^{273}$ It has also permitted politicians to avoid taking difficult stands by delegating many of the most important policy questions to administrative bodies. ${ }^{274}$ One observer has thus rightly concluded that the techniques of "depoliticization" are "neither neutral in themselves nor in the processes of their development and application. Rather, it is their very appearance of objectivity, rationality, and universality that underpins their power and utility." 275

In the international context, a corollary to depoliticization has been the significant increase in the autonomy of administrative actors from hierarchical control, characterized especially by the "growth of international networks at [the] sub-state level" involving "direct contacts between national regulators with specific responsibilities."276 Officials otherwise subject to control and supervision within their national administrative hierarchies have exploited the opportunity to develop "horizontal crossborder contacts with their counterparts in other states, by-passing the coordination of national levels of government and the mediation of diplomatic channels and Foreign Offices." 277 These contacts are usually informal or semi-formal in nature, avoiding conventional legal instruments like treaties in favor of purportedly sub-political "administrative arrangements."278

In some sense, the Community bureaucracy, with the Commission at the summit, constitutes a highly developed form-perhaps even the most

273. For example, Sol Picciotto recounts how, during the Bretton Woods negotiations, the experts involved "were highly political individuals like Harry White, who conducted a clandestine foreign policy," and that key matters were almost always calculated on the basis of political acceptability but "put forward as objective and scientific in order to facilitate acceptance." Picciotto, Networks, supra note 18, at 1037 (citing Raymond F. Mikesell, The Bretton Woods Debates: A Memoir 21-22 (Essays in International Finance No. 192, 1994)).

274. See Pierce, supra note 12 , at $1245-46$.

275. Picciotto, Networks, supra note 18 , at 1037.

276. Id. at 1038; see also Anne-Marie Slaughter, The Real New Worid Order, Foreign Aff., Sept-Oct. 1997, at 183, 189-92 (on the "regulatory web").

277. Picciotto, Networks, supra note 18 , at 1038 .

278. A good example is the so-called Agreement between the Commission of the European Communities and the Government of the United States of America regarding the application of their competition laws of September 1991. The Commission sought to conclude this agreement on its own authority under the EEC Treaty. In a legal challenge by France and other Meniber States, however, the ECJ held that the agreement could not be concluded without the approval of the Council. See Case C-327/91, France v. Commission, 1994 E.C.R. I-3666, 5 C.M.L.R 517 (1994). In reaching the conclusion that the Commission had overstepped its powers by entering into the agreement on its own authority, the Court specifically rejected the argument that the agreement involved purely administrative cooperation between U.S. and EC authorities, rather than cooperation in substantive policymaking, and was thus a nere administrative arrangement. Id. at 3673-74. For a discussion, see George A. Bernann, Regulatory Cooperation Between the European Commission and U.S. Administrative Agencies, 9 Admin. L.J. Am. U. 933, 958-60 (1996). 
highly developed form-of this kind of complex international policy network." "279 However, as the Community experience also demonstrates, the emergence of this sort of autonomous policy network raises a significant problem of democratic legitimacy, given the distance of much of the decisionmaking from national institutions, which, for better or worse, remain the principal vehicle for popular legitimation. ${ }^{280}$

\section{Supranational Technocratic Autonomy and National Control: The Imperfections of the Comitology System}

The comitology system, which governs the Commission's exercise of subordinate legislative power, reflects quite explicitly the desire for some measure of continued Member State control over the Community's normative output. The Comitology Decision of July 1987 established three alternative types of committees-the "regulatory committee," the "management committee," and the "advisory committee"-each charged with overseeing the formulation of subordinate legislation at the Community level. ${ }^{281}$ All are chaired by a non-voting Commission official but staffed by members of national administrations. Of these three types, the regulatory committee involves the highest degree of Member State control, prohibiting a measure from coming into effect until it has been approved by the committee voting by qualified majority. However, the management committee is the more common form of oversight. Under this set up, if the committee rejects the Commission's proposal, again by qualified majority, it is referred to the Council. If the Council rejects the proposal within one month, it is definitively rejected; otherwise, failing Council action, the measure is adopted.282

The establishment of the comitology system must be viewed together with the increased use of qualified-majority voting in the Council following the Single European Act of 1986, as well as with the "new approach to technical harmonization" that came in its wake. ${ }^{283}$ Qualified-majority voting, and the dramatic push to complete the internal market by 1992 via minimal harmonization, necessarily augmented the strategic position of the Commission vis-à-vis the Member States: The first gave the Commission greater freedom in the process of legislative formulation, while the second required extensive delegation of subordinate rulemaking power to the Commission in order to quickly fill out the necessary details. The political message of the Comitology Decision was therefore

279. Recall Professor Majone's characterization of the Commission as the "central node in a vast "issue network'." See supra note 262 and accompanying text.

280. See Picciotto, Networks, supra note 18, at 1055-56.

281. Council Decision 87/373/EEC, 1987 O.J. (L 197) 33.

282. As its name implies, the advisory committee exercises purely consultative functions and thus involves the most iminimal level of Member State control. For a succinct discussion of the three types of committee procedures, see Vos, supra note 39, at 217.

283. See supra text accompanying notes 159-164. 
understandable: Despite the increased autonomy and normative power of the Commission, the Member States were "not willing to loosen their intergovernmental grip on the implementation process in favour of supranational institutions." 284

From the standpoint of preserving Member State control, however, comitology has proven to be a highly imperfect system involving significant risk of agency losses. One problem has been a sort of "Community capture"-that is, a subtle shift in loyalties on the part of the national regulators serving on the various committees at the Community level, who "slowly move from representatives of the national interest to representatives of a Europeanised interadministrative discourse . . ."285 Another problem is the sheer organizational density and complexity of the comitology system, which greatly diminishes the capacity of national administrations to control their agents at the Community level. ${ }^{286}$ There are, according to one estimate, over 250 implementation committees, each of which follows different procedures according to the area regulated. ${ }^{287}$

From another perspective, however, comitology does offer an effective, if subtle form of Member State control, because as a general matter "agents may rationally anticipate the reactions of principals to certain types of behavior." 288 Thus, "agency behavior that at first glance seems autonomous may in fact be subtly influenced by the preference of principals, making genuine agency autonomy exceedingly difficult to measure."289 One political scientist has thus theorized that the Commission, rather than run the risk of a referral of one of its regulatory proposals to the Council, will be highly responsive to Member State preferences. The low rate of committee references to the Council-estimated at less than one percent of all Commission proposals under the comitology systemarguably reflects the Commission's adroit anticipation and avoidance of Member State opposition. ${ }^{290}$

The problem with this theory is that it ignores one fact that could greatly reinforce Commission autonomy: Committee voting is by qualified majority, according to the same weighting which prevails in the Council, thus meaning that the Commission can ignore significant minority positions without threat of referral. ${ }^{291}$ The same concerns over

284. Joerges \& Neyer, supra note 55, at 276; see also Vos, supra note 39 , at 223-24 (describing comitology both as "a reflection of the Member States' concern that the integrity of their own powers be maintained," and as "a concrete expression of the principle of subsidiarity").

285. Joerges \& Neyer, supra note 55, at 291.

286. For a sense of that complexity, see Snyder, supra note 135; see also Areilza, supra note 31 .

287. See Areilza, supra note 31 , at 7 .

288. Pollack, supra note 3 , at 110 .

289. Id.

290. See id. at 114-15.

291. On the vote-weighting under the qualified-majority system, see supra note 162. 
autonomy that arise at the Council level thus reproduce themselves at the committee level. Indeed, a recent study of comitology concluded that the Commission's "room for manoeuvre is by no means substantially constrained by the shadow of majority voting," even where the Commission seeks to promote consensus rather than conflict. ${ }^{292}$ Importantly, the Commission official chairing the committee generally controls both the agenda and the flow of scientific advice, allowing a selective appeal "to the authority and impartiality of science-based findings" where necessary to overcome potential political opposition. ${ }^{293}$ Thus, "[f] rom a supranational perspective, it is not the Member States' interests which dominate European politics but rather European institutions which have the capacity to channel and influence Member State interaction in a way that is compatible with European interests." 294

\section{D. "Deliberative Supranationalism"}

Commentators like Giandomenico Majone, who welcome this kind of supranational regnlatory autonomy, nevertheless recognize the significant legitimacy problems raised by the current state of affairs. Professor Majone characterizes the comitology system as "ad hoc" and "the very negation of the idea of transparency." ${ }^{295} \mathrm{He}$ thus calls on the Community to adopt something like the United States Administrative Procedure Act (APA), both to increase transparency and to rationalize the system of participation and thus to "do more to make public accountability possible than the wholesale transfer of traditional party politics to Brussels."296 Christian Jeorges and Jürgen Neyer have also written approvingly of the development of European administrative procedures at least in part inspired by the American model ${ }^{297}$ as a means of facilitating what they call "deliberative supranationalism."298 This concept comprises, among other things,

the establishment of fora where the views of all concerned [groups] can be included; legal principles and rules civilising the decision-making process and providing an institutional context for practical reasoning; [management of] tensions between output rationality (high standards), procedural transparency

292. Joerges \& Neyer, supra note 55, at 279.

293. Id. at 281.

294. Id. at 289 (citing Bach, Vom Zweckverband zum technokratischen Regime: Pohtische Legitimation und institutionelle Verselbständigung in der Europäischen Gemeinschaft, in Nationalismus-Nationalitäten-Surpanationalitāt (H.A. Winkler \& H. Kaelble eds., 1993)). Jeorges and Neyer still stress that the Commission emphasizes consensus over conflict-indeed, is dependent on ongoing cooperation-and thus must be seen as acting as an honest broker. See id. at 288-89. In my view, this mitigates only slightly the threat of agency losses from the Meinber State standpoint.

295. Majone, Regulatory State, supra note 55, at 95.

296. Id.

297. Joerges \& Neyer, supra note 55, at 283-85.

298. See generally id. at $290-97$. 
and fairness; ... [and] the generation and dissemination of knowledge. 299

For the moment, however, such proposals remain vague, leaving a good deal of room for speculation about what a European procedural code will in fact entail and how it will be integrated into existing intergovernmental processes. ${ }^{300}$

At least on the scientific/technical consultation side of the equation-as opposed to the public participation side-there is already some basis in both ECJ decisions and in the EC Treaty for certain procedural requirements along these lines. ${ }^{301}$ In a decision concerning standards governing cosmetics, for example, the ECJ held that it was unlawful for the Commission and the relevant comitology committee to adopt rules without first consulting the so-called Scientific Committee on Cosmetology. ${ }^{302}$ Such consultation was mandatory, the Court stated, because the rules in question needed to be "founded on scientific and technical assessments which must themselves be based on the results of the latest international research." 303 Indeed, the Court went so far as to say that technical and scientific consultation was required by "the nature of things and apart from any provision laid down to that effect."304

In addition, Article 253 (ex Article 190) of the EG Treaty sets forth a procedural requirement that also seems designed to promote rational deliberation. This article provides that all acts of the Community which are intended to produce legal effects (regulations, directives, and decisions) "shall state the reasons on which they are based and shall refer to any proposals or opinions which were required to be obtained pursuant to this Treaty." 305 However, the actual language of Article 253 (ex Article 190 ), as well as ECJ case law, limits the utility of this provision in two important respects. First, on its face it requires no public consultation or

299. Id. at 299. For similar views among other European commentators, see Armstrong, supra note 17, at 171; Everson, Administering Europe?, supra note 55, at 213-14; Sand, supra note 8, at 292-98.

300. For a view from the American side that attempts to fill the speculative void, see Francesca Bignami, The Administrative State in a Constitutional System of Checks and Balances: Lessons for EC Comitology from American Rulemaking, Harvard Jean Monnet Chair Working Paper Series No. 5/99, <www.law.harvard.edu/Programs/JeanMonnet/ papers $/ 99 / 990501 / \mathrm{html}>$ (printout of the online version on file with the Columbia Law Review).

301. Shapiro, supra note 55 , at $44-45$.

302. Case 212/91, Angelopharm GmbH v. Freie und Hansestadt Hamburg, 1993 E.C.R. I-171.

303. Id. at I-210.

304. Id. at I-211.

305. See EC Treaty art. 253 (ex art. 190). Article 253 obviously brings to mind the APA's requirement that newly-adopted rules include " a concise general statement of their basis and purpose," which has given American courts a basis to promote reasoned administrative decisionmaking by ensuring that agencies have taken a "hard look" at all the relevant materials im the record. Strauss, From Expertise to Politics, supra note 63, at 756-57 (citing Administrative Procedure Act, 5 U.S.C. \$ 553(c)(1994)). 
response to public comments but simply that the enacting body "refer" to "any proposals or opinions which were required to be obtained pursuant to this Treaty," i.e., from publicly-constituted bodies like the Community's Economic and Social Committee.$^{306}$ Second, unlike the Commission, whose discretion the Court controls more closely, the Court does not apply the requirements of this provision to the Council with any great rigor. The ECJ "tends to treat the Council as a normal legislature, enjoying a very wide margin of discretion." ${ }^{307}$ This deference is clearly contrary to the administrative character of the Council, the net effect of which is to preclude an effective examination of the rational underpinnings of much of the Community's primary legislative output. ${ }^{308}$ The limitations of Article 253 (ex Article 190), both facially and as applied, indicate that more stringent requirements are needed in the Treaty to ensure transparency and participation rights at the European level.

\section{E. The Normative Yearning for Legitimate Political Control: Lessons from the American Experience}

Leaving aside the dearth of details in many of the current proposals regarding a European procedural code, however, their basic thrust is clear: Such a code should follow the perceived model of the APA and other American administrative procedure statutes with broadly based, legally enforceable rights of participation and transparency. Such rights should produce, to paraphrase one sympathetic American observer speaking in another context, "a publicly accountable, technocratic policy choice" through rules requiring "administrators to be open to the range of scientific and technical opinion and to develop a sensitivity to the interests of various groups." 309

Before the Community proceeds too quickly down this road, however, Americans might offer a word of warning to Europeans not to be too selective in their regard for the American experience. At a minimum, Europeans should understand that the necessary corollary to administrative proceduralization is more searching judicial review, particularly in the absence of adequate hierarchical controls. The potential consequence is a form of "adversarial legalism" that private interests and judges

306. Generally such references are just that: perfunctory statements, usually in the preamble (e.g., "having regard to the report of the ... "), without any obligation to respond to germane concerns raised.

307. Joerges \& Neyer, supra note 55, at 286 (citing, e.g., Case C-331/88, The Queen v. Minister for Agriculture, Fisheries and Food and Secretary of State for Health, ex parte: Fedesa and Others, 1990 E.C.R. I-4023, I-4063).

308. The full implications of this deference will be examined in greater detail infra Part VI, in connection with the ECJ's subsidiarity case law. See infra notes 417-434 and accompanying text.

309. Rose-Ackerman, Controlling Environmental Pohicy, supra note 69, at 84 (comparing the German licensing processes favorably with "the more secret, consensual processes characteristic of policy-making in other areas of German law'). 
can clearly abuse. Therefore, Europeans should be on guard against what Americans call "ossification of rulemaking" in all its aspects. ${ }^{310}$

Perhaps more importantly, however, Europeans should also not ignore the strong and increasingly important hierarchical dimension of the American experience, particularly over the last two decades. ${ }^{311}$ By "hierarchical dimension" I do not mean simply the efforts of recent U.S. Presidents-from Carter through Clinton-to take on a central role in coordinating regulatory policy among various agencies on the basis of costbenefit principles. ${ }^{312}$ Europeans may mistakenly view these sorts of political controls solely from the standpoint of sound policy or efficient institutional design, which might somehow be replicated at the Community level through existing institutions or new mechanisms of regulatory coordination. 313

Presidential efforts to assert control over the regulatory process, rather, are part of a larger story of "normative yearning," if you will, for democratic legitimacy within the American administrative state. In some European academic commentary, one detects a sometimes dismissive tone toward those who stress the need for similar forms of centralized, legitimate political oversight at the Community level, seeing it as evidence of "limited" political theory and a misunderstanding of "how regulation may be tangibly reduced to a technical task, devoid of redistributive policy implications." 314 If anything, American scholars have come to precisely the opposite conclusion, that regulatory issues-or at least the major questions of social regulation (which often have a very significant economic impact)-are inherently political, thus requiring explicitly political control. ${ }^{315}$ In some sense, the current disquiet in both Europe

310. For a succinct overview, see Strauss, From Expertise to Politics, supra note 63, at $756-66$.

311. For a summary, see id. at 761-63. Joerges \& Neyer, supra note 50 , at 285 , are appropriately cautious regarding the American model when they write that "[a]dvocates of a European act on administrative procedures ... may underestimate the dependence of administrative law models on the organisational structure and the social conditions of nation states or federations."

312. See, e.g., Exec. Order No. 12,291, 3 C.F.R. 127 (1982), reprinted in 5 U.S.C. $\S 601$ (1988) (revoked by Executive Order No. 12,866 (1994)); Exec. Order No. 12,866, 3 C.F.R. (1994), reprinted in 5 U.S.C. $\$ 601$ (1994).

313. See Majone, Independent Fourth Branch, supra note 55, at 42-43; Majone, "Deunocratic Deficit," supra note 55, at 25-27; Majone, Regulatory State, supra note 55, at 95-97; Majone, Temporal Consistency, supra note 55, at 7.

314. Everson, Independent Agencies, supra note 55, at 197; see also Majone, "Democratic Deficit," supra note 55, at 26 (discussing "how the present understanding of the logic of delegation casts doubt on the validity of the received view concerning the delegation of powers by community imstitutions to ad hoc bodies not envisaged by the founding Treaties").

315. See generally Strauss, From Expertise to Politics, supra note 63. Professor Majone acknowledges that "redistributive policies can be legitimated only by majoritarian means and thus cannot be delegated to institutions independent of the political process." Majone, "Democratic Deficit" supra note 55, at 28. He distinguishes redistributive policies from "efficiency-oriented policies" that "are basically legitimated by results, and hence may 
and the United States over administrative institutions reflects strong popular reservations about-if not outright rejection of - the epistemological distinction between politics and expertise that has in the past provided the cultural underpinnings of modern administrative autonomy. ${ }^{316}$

A misreading of the apparent success of the American model-with (as one European admiringly describes it) its "imaginative, novel and above all flexible means to ensure institutional and public accountability"317_has in my view given some European academic observers a false hope: that the average European will eventually come to accept, as Americans purportedly have, a decentralized, non-hierarchical administrative system which no one actually "controls" directly, but which is nevertheless "under control."318 This statement glosses over the fact that most American citizens likely do not consciously share this sanguine view. I strongly suspect most people-including Europeans-want to believe that administrative bodies are in fact, or at least should be, "under the control" of some ultimately accountable elected official or officials. ${ }^{319}$

be delegated to such institutions, provided an adequate system of accountability is in place." Id. Although he understands that "efficiency-enhancing policies, like all public policies, will normally have redistributive impacts," Professor Majone asserts that "[$[t]$ his is not a serious problem if the efficiency gains are large enough to compensate the losers, and if it is politically feasible to do so." Id. This begs a number of critical questions concerning efficiency gains and political feasibility that Americans have come to recognize are inumately bound up with administrative policymaking, requiring democraticallylegitimate political control. For Professor Majone, however, although this may be true on the national level, one of the main advantages of supranationalism is that it somehow separates problem-solving and bargaining over the distribution of gains. He does not specify how this is so, stating only that "Member States that are negatively affected by a collective decision, at least in the short run, are generally compensated in some way." Id. Professor Majone leaves unexplained, however, what that "some way" is.

316. See supra notes 264-265 and accompanying text.

317. Everson, Independent Agencies, supra note 55, at 189. Everson is referring to $\mathrm{OMB}$ coordination combined with congressional oversight, administrative procedure, and judicial review. See id. at 190-93.

318. Everson, Independent Agencies, supra note 55, at 190 (citing Terry Moe, Interests, lnstitutions and Positive Theory: The Politics of the NLRB, 2 Studies in American Development 236 (1987)); see also Majone, Independent Fourth Branch, supra note 55, at 29 (citing the saine article by Moe). Everson, Independent Agencies, supra note 55, at 202-03, is admittedly cautious regarding the possibility of establishing independent agencies at the European level, although her arguments would seem to apply to the Community as a whole and not just to the subordinate independent agencies she envisions. She acknowledges the need for greater instruments of direct accountability between the Member States and European agencies, apart from Member State representation in the Council of Ministers, implicitly accepting the linkage between democratic legitimacy at the national level and hierarchical political control. She also worries about the dramatic increase in litigation that would likely follow her proposed broad delegation of regulatory authority to European independent agencies. Fimally, she acknowledges the criticisms of those who argue that there does not yet exist a European "public" to which European agencies could be made directly accountable through a European code of administrative procedure. Id.

319. Even though the European Commission is not an elected body, this desire for political control, I believe, explains the very strong tone contained in the recent report of 
Of course, the idea that the system is "in control," and yet no politically responsible entity actually controls it, begs the question of democratic legitimacy. Even if the system is somehow vaguely "in control," it must be so in the service of some interest which may or may not be in line with the views of the current political majority-indeed, per Professor Majone, this is one of the main virtues of administrative independence. ${ }^{320}$ Whatever the advantages of such independence on "sound policy" grounds, it is truly a contortion of prevailing understandings of democratic legitimacy to disparage or ignore the need for hierarchical political control, either executive or legislative, in such a forthright way. To the contrary, the widespread popular realization that elected representatives are not, somehow, in control of administrative action is, I would argne, responsible for much of the political anxiety about the modern administrative state. The perception of a supranational technocracy beyond democratic control is, in fact, at the core of popular concerns about the democratic deficit in Europe, contrary to the views of those who celebrate the virtues of administrative autonomy at the Community level. These concerns will thus not be easily dissipated simply by establishing a "subtle, complex and detailed catalogue of mechanisms" inspired by the purportedly "non-hierarchical" American example. ${ }^{321}$

In the United States, decisions of the Supreme Court in such cases as Cheoron, U.S.A., Inc. v. Natural Resources Defense Council, Inc. ${ }^{322}$ and Lujan

the Committee of Independent Experts that led to the resignation of the Commission on March 16, 1999. See generally Independent Experts Report, supra note 205. The report treated the Commission as having the same hierarchical political responsibilities over the administrative functions of the Community as cabinet ministers have in a national parliamentary system. The final paragraph of the report states:

The responsibility of individual Commissioners, or of the Commission as a body, cannot be a vague idea .... The studies carried out by the Committee [of Independent Experts] have too often revealed a growing reluctance among the members of the hierarchy to acknowledge their responsibility. It is becoming difficult to find anyone who has even the slightest sense of responsibility. However, that sense of responsibility is essential. It must be demonstrated, first and foremost, by the Commissioners individually and the Commission as a body. The temptation to deprive the concept of responsibility of all substance is a dangerous one. That concept is the ultimate manifestation of democracy.

Id. at 144, para. 9.4.25.

320. Terry Moe, whom both Everson and Majone cite, see Everson, Independent Agencies, supra note 55, at 190 (citing Terry Moe, Interests, Institutions and Positive Theory: The Politics of the NLRB, 2 Studies in American Development 236 (1987)); see also Majone, Independent Fourth Branch, supra note 55, at 29 (citing the same article by Moe), has pointed this out in the American context. See Terry Moe, The Politics of Bureaucratic Structure, in Can the Government Govern? 275 (Chubb \& Peterson eds., 1989) (arguing that interest groups generally favor "structural designs [they] would never favor on technical grounds alone: designs that place detailed formal restrictions on bureaucratic discretion, mpose complex procedures for agency decisionmaking, minimize opportumities for oversight, and otherwise insulate the agency from politics. The group has to protect itself and its agency from the dangers of democracy ...." (emphasis added)).

321. Everson, Independent Agencies, supra note 55, at 203.

322. 467 U.S. 837 (1984). 
v. Defenders of Wildlife $e^{323}$ are the tangible legal expression of the normative yearning for democratic accountability and control that I have described. ${ }^{324}$ The Supreme Court in Cheuron held that American courts should defer to a reasonable agency interpretation of the scope of its delegated statutory authority if Congress has not precisely spoken to the question in the enabling legislation. The Court reasoned that "[w]hile agencies are not directly accountable to the people, the Chief Executive is, and it is entirely appropriate for this political branch of the Government to make such policy choices . . ." ${ }^{\text {325 }}$ As Cynthia Farina has described, the Court's implicit message is:

Deference is right not because it yields better answers, more efficient answers, or even the answers Congress would have wanted, but because it yields more legitimate answers. The Cheoron mystique flows from this promise that the ordinary act of statutory interpretation can advance the larger process of reconciling agencies with constitutional democracy. 326

For Professor Farina, the decision in Lujan is an even more dramatic demonstration of the hope that the President will supply legitimacy to the administrative state. Lujan involved the scope of the power of Congress to confer standing by means of a so-called "citizen-suit" provision, authorizing "any person" to bring action to enforce the provisions of a public interest statute. The Court held that a "citizen-suit" provision was insufficient to confer standing to vindicate "procedural injuries" in the absence of a concrete injury flowing from the procedural violation of the statute. ${ }^{327}$ Justice Scalia characterized plaintiffs' claim as merely part of "the undifferentiated public interest in executive officers' compliance with the law" which Congress could not convert, by means of a citizen-suit provision, "into an 'individual right' vindicable in the courts . . .."328 Most importantly, emphasizing a strict separation-of-powers rationale, Justice Scalia asserted that excessive judicial involvement in supervising administrative procedures "transfer[s] from the President to the courts the Chief

323. 504 U.S. 555 (1992).

324. See Cynthia R. Farina, The "Chief Executive" and the Quiet Constitutional Revolution, 49 Admin. L. Rev. 179, 181-83 (1997).

325. Cheoron, 467 U.S. at 865.

326. Farina, supra note 324 , at 183.

327. 504 U.S. 555, 571. The case arose out of newly-promulgated regulations under the Endangered Species Act (ESA). See id. at 558. Section 7(a) (2) of the ESA (codified at 16 U.S.C. \$1536(a) (2) (1994)) requires interagency consultation for any agency action likely to jeopardize the existence of an endangered species. Prior regulations interpreted this provision to require consultation if the action affected a species abroad (such as funding a project in the developing world). However, the new regulations narrowed the consultation requirement to actions within the United States or on the high seas. See 504 U.S. at 558. Plaintiffs sued to restore the broader interagency consultation, despite the fact that they had no right to be consulted themselves. Plaintiffs based their right of action on the "citizen-suit" provision in the ESA. See id. at 571-721.

328. Id. at 577. 
Executive's most important constitutional duty, to 'take Care that the Laws be faithfully executed." 329

The effect of these and other decisions ${ }^{330}$ is to reinforce the ultimate responsibility of the President for policymaking in the administrative sphere. ${ }^{331}$ Whether this makes sense in the American context in light of the President's actual capacities of control and oversight is another matter that need not be addressed here. ${ }^{332}$ What is important for our purposes is that the normative yearning for such ultimate responsibility exists, and that those Europeans who take inspiration from the perceived example of the United States must not ignore it. ${ }^{333}$

329. Id. (quoting U.S. Const., art. II, § 3).

330. See, e.g., Thunder Basin Coal Co. v. Reich, 510 U.S. 200 (1994) (holding that petitioner was not entitled to bring a pre-enforcement challenge to an agency order in circumstances where the enabling statute provided a comprehensive review scheme and no serious deprivation would arise froin postponing review); Reno v. Catholic Soc. Servs., Inc., 509 U.S. 43 (1993) (holding that, where a regulation simply limits an applicant's right to receive a government benefit, an action challenging the legality of the regulation will not be ripe until the agency has actually refused the application for the benefit in question).

331. Also to the same effect is the Paperwork Reduction Act, 44 U.S.C. $\$ \$ 3501-3520$ (1994), which gives the President's Office of Management and Budget (OMB) control over the amount of paperwork generated by both executive and independent agencies. One should also cite the Small Business Regulatory Enforcement Fairness Act of 1996, which added a new chapter 8 to Title 5 of the United States Code, 5 U.S.C.A. $\$ 801$ et seq., establishing a new regime for Congressional review of agency regulations. For a critical appraisal, see Daniel Colien \& Peter Strauss, Congressional Review of Agency Regulations, 49 Admin. L. Rev. 95 (1997).

332. See Farina, supra note 324, at 185 ("It seems to me that it is unrealistic to think that the President can supervise the entire regulatory enterprise in a comprehensive and meaningful way."); see also Lindseth, Comparing Admisistrative States, supra note 73, at 617-18 ("The [Lujan] decision, in pointing toward a more narrow judicial role in supervising administrative procedures, assumes a certain degree of hierarchical authority of the President over the administrative sphere which may not correspond to reality.").

333. It is perhaps another measure of the administrative character of the European Community that its conpetences in economic and social regulation correspond roughly to those regulatory domains over which the U.S. President has, in principle, the least claim to direct political control. Nevertheless, even in those areas, the desire for administrative accountability through Presidential supervision is still quite strong. One might also note that those domains in which the President has the greatest claim to control-defense, foreign affairs, law enforcement-correspond precisely to those that the Member States have largely excluded from Community jurisdiction under the "pillar structure" of the European Union: common foreign and security pohicy (the "second pillar") and justice and home affairs (the "third pillar"). See supra notes 91-93 and accompanying text. It should be noted that, under the Treaty of Amsterdam, the Community gains competences in many areas under the third pillar. However, this transfer of sovereignty was only made possible by guaranteeing certain Member States the right to derogate, im effect restoring a kind of hierarchical control. See supra notes 180-181 and accompanying text. 


\section{Democratic Legitmacy and Treaty Interpretation}

\section{A. A Presumption against Supranational Normative Autonomy}

If one were to take the legitimacy principles enunciated by the United States Supreme Court over the last decade and a half (notably in Chevron) and apply them to the European case, the outcome would arguably be precisely the opposite of what one finds in the American constitutional context. Under the currently prevailing judicial doctrine in the United States, the search for democratic legitimacy now tends to favor the normative autonomy of agencies, at least relative to the courts. Such autonomy is justified by the President's (sometimes admittedly theoretical) oversight over the administrative sphere, combined with the President's undoubted electoral accountability to the American people. From the Supreme Court's perspective, this accountability renders the executive branch a more democratically legitimate interpreter of legislative ambiguity than the courts.

There is, however, no equally accountable hierarchical superior in the European Community, for all the reasons I have already put forward. If, as one American commentator has argued, it is ultimately the responsibility of the American judiciary, and notably of the Supreme Court, to ensure "the continuing vitality of the principal-agent relationship between the people and government," 334 the same goes for the European courts, both at the national and the Community level. The judicial enforcement of a kind of "direct" democratic discipline through broader transparency and participation rights undoubtedly has a role to play in ensuring that vitality. ${ }^{335}$ However, the ECJ and the national courts must begin with the premise that the locus of democratic legitimacy in the European Community remains with the Member States, and that the courts must construct public law doctrines-especially those relating to the interpretation of the extent of Community competences under the EC Treaty-in light of this fact.

Where the "legislative" intent of the Treaty is ambiguous on a particular point, ${ }^{336}$ the European courts should, in effect, apply a Cheoron-type interpretive presumption in favor of national institutions and against the

334. Pierce, supra note 12, at 1240.

335. See Cohen \& Sabel, supra note 70.

336. This argument presumes that the EC Treaty is best understood, not as a constitution, but as a kind of enabling legislation. In interpreting the scope of the EC's delegated legislative, executive, and adjudicative authority under the Treaty, European courts should of course attempt to enforce the intent of the parties. But that intent will often be ambiguous at best, given that the "legislation" results from intergovernmental negotiation among fifteen different countries, as well as from a variety of ratification procedures. In this sense, one of the preconditions that Professor Majone identifies for delegation of normative power to supranational institutions-the "precise[] and narrow [ ]" definition of regulatory tasks, see Majone, "Democratic Deficit," supra note 55, at 28-becomes very difficult to achieve. For a concrete example, see the discussion of the Community's power to legislate in the area of workers' "health and safety" under the old Article 118a, discussed infra note 462 and accompanying text. 
Community qua supranational administrative agency, in order to restrict the scope of the latter's normative autonomy relative to the more democratically legitimate Member States. There are two broad categories of cases in which I can envision this presumption clearly applying. The first comprises those cases where there is ambiguity in the relative meaning and scope of potentially conflicting Community and national laws. Here, the European courts-both national and supranational-should presumptively favor interpretations maximizing Member State control, so long as they are reasonable in light of the broader goal of integration. The second includes cases where two possible legislative bases exist for Community legislation under the EC Treaty, one requiring unanimity in the Council of Ministers and the other permitting qualified- or simplemajority voting. Here, the ECJ should presumptively favor the legislative basis requiring unanimity, unless there exists clear evidence of a contrary intent on the part of the Member States at the adoption of the provisions of the Treaty in question.

The interpretive presumption that $I$ am advancing admittedly is grounded in "a general skepticism when confronted with [supranationally] produced laws." 337 Such skepticism, however, should not be confused with "hostility or even the functional equivalent of a presumption against the validity of [a supranational] rule." 338 Rather, it reflects the realization that the national decisionmaker, "even if a bureaucrat, still bears some political accountability for its choices; the [supranational] lawmaker does not. What underlies the skeptical position is the belief that the more accountable decisionmaker should receive the benefit of the doubt." 339

337. Stephan, supra note 47 , at 729 .

338. Id.

339. Id. at 732. Professor Stephan articulates this principle in order to deal with potential conflicts between the GATT and domestic U.S. law. He argues:

What emerges from this and other trade law cases is a hierarchy; when statutory ambiguity exists, international law trumps a court's independent guess as to what domestic law requires but not the administrative agency's. Where the executive accepts the international organ's position, the court will support the agency's choice unless the plain language of the statute clearly requires otherwise. But where the responsible agency disagrees with the international body, the court will side with the domestic decisionmaker.

Id. (citing Footwear Distribs. and Retailers of Am. v. United States, 18 C.I.T. 391 (1994), appeal dismissed, 43 F.3d 1486 (Fed. Cir. 1994)). In my view, the hierarchy that Professor Stephan is articulating is simply an application to the GATT context of the well known Cheoron "two-step." Cheoron requires judges first to determine whether Congress has unambiguously spoken to the precise question at issue; then if not, to defer to any reasonable agency imterpretation. See Chevron U.S.A., Inc. v. Natural Resources Defense Council, Inc., 467 U.S. 837, 842-43 (1984). The Cheoron "two-step" implies a hierarchy of normative legitimacy, with Congress at the top, followed by the administrative agency (which draws its legitimacy from the President), after which come the courts. Professor Stephan is effectively arguing for a similar hierarchy in the GATT context: first, Congress's expressed position in the statute; second, the interpretation of the statute by the administrative agency (if Congressional intent is ambiguous); third, the position of the 


\section{B. Teleological Interpretation and the Constitutionalist "Preference for Europe"}

Of course, the notion that national decisionmakers are presumptively entitled to the benefit of the doubt in disputes with Community institutions would constitute something of a revolution in ECJ jurisprudence, running contrary to a long interpretive tradition built up over nearly four decades. According to one judge of the European Court of Justice, writing with a collaborator in 1994, there is a "preference for Europe" that the drafters of the Treaty built into "the genetic code transmitted to the Court."340 This preference is central to the Court's constitutionalist vision of the Community. The overarching obligation of the ECJ is, in this view, to pursue the primary objective of the EC Treaty as set forth in the Preamble: "an ever closer union among the peoples of Europe." 341 The internal market is the cornerstone of that "ever closer union," and together they constitute the very purpose-the "telos"-of the EC. The method of Treaty interpretation geared to achieving this telos-the "teleological method"-has thus dominated the reasoning of the European Court of Justice since the early 1960s. ${ }^{342}$

1. Direct Effect and l'effet utile. - One could already see the teleological method at work in perhaps the most celebrated judgment in the history of European "constitutionalism," Van Gend $\mathcal{E}^{2}$ Loos, handed down in 1963. ${ }^{343}$ At issue was whether a provision in Article 12 of the EEC Treaty

international organ (which, in effect, indirectly exercises delegated normative power of Congress and the President); and fourth, the intexpretation by the doinestic courts.

But see Croley \& Jackson, supra note 4, at 206-11, who question whether Cheoron provides useful analogies for the GATT/WTO context. Professors Croley and Jackson regard democratic legitimacy as only the second of three justifications for Cheoron deference, along with agency expertise and efficiency or coordination, see id. at 206-07, whereas I view it as the decisive underlying value of the doctrine. Moreover, they regard "the GATT/WTO membership at large" as the legitimate pohitical principal in the system, rather than particular member states as representatives of their national communities. Id. at 209. Therefore, "[ $[$ ] he argument in Cheoron that judges should defer to the interpretive decisions made by those accountable to the citizenry's representatives simply has no analogue in the GATT/WTO antidumping context." Id. However, by regarding "the GATT/WTO membership at large" as the relevant pohitical principal, Professors Croley and Jackson give preeminence to the needs of international cooperation and coordination over those of democratic legitimacy, thus effectively ignoring the issue of the democratic deficit when normative power is delegated outside the confines of the nation-state. For further discussion, see supra notes 527-529 and accompanying text.

340. Mancini \& Keeling, supra note 201, at 186.

341. See EC Treaty preamble.

342. See generally Fennelly, supra note 140 . For a view from the early 1970 s of a thenjudge on the ECJ, see Pescatore, supra note 146, at 86-90. The late Judge Fernand Schockweiler discussed the teleological method as giving "preference to the interpretation best fitted to promote the achievement pursued by the objectives pursued by the Treaty." Fennelly, supra note 140 , at 668 . Fernand Schockweiler, La Cour de justice des Communautés européennes: dépasse-t-elle les limites de ses attributions?, 18 Journal des tribunaux, Droit européen 74 (Apr. 20, 1995).

343. Case 26/62, 1963 E.C.R. 1. 
prohibiting new customs duties ${ }^{344}$ had "direct effect"; that is, whether an individual could enforce its obligations against the Member State in a national enforcement proceeding. In order to determine the meaning of the provision, the EGJ spoke of the need to consider not merely the wording of the Treaty, but also its "spirit" and "general scheme."345 In finding that Article 12 was in fact directly effective, the Court-somewhat vaguely-stressed the Preamble's reference to "peoples" and not merely governments, along with the overall objective of the Treaty to establish a Common Market, for which the Member States had transferred sovereiguty to supranational institutions. ${ }^{346}$ Only then did the Court turn to the "clear and unconditional" terms of Article 12's prohibition to find that it did "not require any legislative intervention" on the part of the Member States. ${ }^{347}$

The Court's reasoning in Van Gend $\mathcal{E}$ Loos manifested another element of the ECJ's teleological approach: the so-called doctrine of l'effet utile ("useful effect"). According to this doctrine, "once the purpose of a provision is clearly identified, its detailed terms will be interpreted so 'as to ensure that the provision retains its effectiveness." 348 Innocuous in the abstract, the doctrine has in fact enabled the ECJ to arrogate to itself an extraordinary degree of normative power, sometimes bending or ignoring literal meanings of Treaty provisions, other times "fill[ing] in gaps, quite unashamedly, without hesitation." 349

344. See EC Treaty art. 25 (ex art. 12).

345. 1963 E.C.R. at 12.

346. See id.

347. Id. at 13.

348. Fennelly, supra note 140 , at 674 (quoting case $9 / 70$, Grad v. Finanzamt Traunstein, 1970 E.C.R. 825, 837, para. 5).

349. Id. at 674 (quoting Lord Denning in James Buchanan \& Co., Ltd. v. Babco Forwarding and Shipping (U.K.) Ltd., [1977] 1 All E.R. 518, [1977] 2 C.M.L.R. 455). In Van Gend $\mathcal{E}^{2}$ Loos, for example, the Court took a maximalist approach with regard to its powers under the preliminary reference procedure of EEC Treaty Article 177, which conferred jurisdiction on the Court to answer questions posed by national courts concerning "the interpretation of [the] Treaty." EC Treaty art. 234(a) (ex art. 177(a)). In that case, the Court held that this provision gave it the power not only to interpret the Treaty but also to rule on the conformity of national law with Community law. The problem with this conclusion-pointed out by both the Dutch and Belgian governments in their arguments to the Court-was that Articles 169 and 170 of the EEC Treaty (now Articles 226 and 227 of the EC Treaty) set forth a seemingly exclusive mechanism for this sort of legal control, one which involved "traditional public-international-law-type provisions offering a kind of declaratory relief for the Community or a Member State." Lenaerts, Interaction, supra note 102, at 98 . Nevertheless, the Court found that "[a] restriction of the guarantees against an infringenient of [Community law] by [the] Member States to the procedures under Articles 169 and 170 would remove all direct legal protection of the individual rights of their nationals." The Court argued that "recourse to the procedure under these Articles would be ineffective if it were to occur after the implementation of a national decision taken contrary to the provisions of the Treaty." Van Gend $\mathcal{E}^{\circ}$ Loos, 1963 E.C.R. at 13. Hence, the Court found a need for a broad interpretation of the its powers under Article 177. 
2. Supremacy - Standing alone, the combination of direct effect, teleological interpretation, and its corollary, the doctrine of l'effet utile, would be a potent formula for an expansive understanding of supranational adjudicative power. One final foundational element, however, remained to be articulated: the doctrine of the supremacy of Community law over national law, which was implicit in Van Gend $\mathcal{E}$ Loos but not formally announced by the Court until its judgment in Costa v. ENEL in $1964 .{ }^{350}$ The original Treaty of Rome lacked-and the EC Treaty still lacks-an explicit supremacy clause. ${ }^{351}$ In Costa, the Court nevertheless found that the Treaty constituted "a permanent limitation of [the] sovereign rights" of the Member States, ${ }^{352}$ despite the fact that, in certain Member States-like Italy, where the decision arose-the Treaty had been ratified by simple statute. By looking broadly at "the terms and the spirit of the Treaty,"353 the Court concluded that it was impermissible for a Member State to give precedence to its own laws over those of the Community, regardless of the constitutional status of the Treaty in domestic law. ${ }^{354}$ Supremacy flowed from the need for uniformity. ${ }^{355}$

As a leading European jurist has put it, "[e]ffectiveness, supremacy, and uniform judicial enforcement of Community law" are the key doctrinall achievements of the "constructionist stage" of ECJ case law. ${ }^{356}$. The procedural and substantive consequences in national law were understandably profound. Procedurally, the ECJ's aggressive pursuit of its vision of the Community's telos led to an extensive involvement in the judicial systems of the Member States. For example, the Court required national courts to offer effective remedies in the enforcement of Community law even if this meant overriding domestic constitutional traditions. ${ }^{357}$ Substantively, the aggressive approach involved a broad interpretation of the "four freedoms"-free movement of goods, persons, serv-

350. Case 6/64, Costa v. ENEL, 1964 E.C.R. 585.

351. Instead, the Treaty has simply required the Member States to "ensure . . . the obligations arising out of the Treaty" and otherwise prohibits them from taking "any measure which could jeopardize [its] objectives." EC. Treaty art. 10 (ex art. 5).

352. Costa, 1964 E.C.R. at 594.

353. Id. at 593 .

354. From a domestic Italian constitutional perspective, because the Treaty had been adopted by legislation, see Law No. 1203 of October 14, 1957, the Italian Constitutional Court had ruled that the Treaty had only the status of Iegislation, and thus was subordinate to subsequent legislation. See George Bermann et al., Cases and Materials on European Community Law 193-94 (1993).

355. According to the Court: "The executive force of Community law cannot vary from one State to another . . . without jeopardizing the attainment of the objectives of the [EEC] Treaty set out in Article 5(2) . ..." Costa, 1964 E.C.R. at 594.

356. Lenaerts, Interaction, supra note 102 , at 96.

357. Case C-213/89, The Queen $v$. Secretary of State for Transport ex parte Factortame Ltd., 1990 E.C.R. I-2433 (holding that a U.K. court must have the power to strike down an act of Parliament if that act violated Community law, despite the prior lack of such judicial power); Case 106/77, Amministrazione delle Finanze dello Stato v. Simmenthal SpA, 1978 E.C.R. 629 (holding that Community law required that every Italian court, not just the Constitutional Court, have the power to hold a domestic statute invalid 
ices, and capital —often bringing Community law into direct conflict with national laws that might have an indirect impact on these freedoms. ${ }^{358}$

3. Community Competence and Internal Institutional Balance. - Perhaps the most profound effects of the teleological method, however, have been felt in the ECJ's jurisdictional and institutional decisions relating to the Community itself. These include, notably, cases exploring the Community's "implied powers" relative to the Member States, as well as those dealing with the balance of power among the Community's own legislative institutions, as reflected in decisions considering the appropriate "legal basis" for Community legislation under the Treaty. ${ }^{359}$ These cases share a common concern: defining in legal terms the new boundary between the Community's authority and the Member State's residual sovereign prerogatives.

a. Implied Powers. - In the Court's 1971 judgment in the ERTA case, ${ }^{360}$ the ECJ outlined the basic principles of the Community's implied powers. The issue was whether the authority conferred on the Community under EEC Treaty Article $75,{ }^{361}$ which covers the implementation of a common transport policy within the Community, extended to the negotiation and conclusion of international agreements with third countries-in this case the European Road Transport Agreement, or ERTA. The then-six Member States claimed the right to negotiate individually, even though the Community had adopted common rules in this area.

In ERTA, the Council argued that, because the Community possessed only delegated powers, the "authority to enter into agreements with third countries cannot be assumed in the absence of an express provision in the Treaty." ${ }^{62}$ The Commission argued, by contrast, that in those circumstances where the Community had in fact adopted internal rules on the subject-as was the case here-the Member States lost their right to negotiate individually because separate agreements might jeopardize the common policy adopted under then-Article 75. The Commission further argued that the narrow interpretation of this provision wrongly excluded it from the process of negotiation of the ERTA, as was its right under EEC Treaty Article 228, ${ }^{363}$ which conferred on the Com-

if it violated Community law, eliminating the Constitutional Court's monopoly of such authority under Italian law).

358. For example, in the area of free movement of goods, the ECJ held that a potential and indirect hindrance to interstate trade was sufficient to strike down a Member State requirement. See Case 8/74, Procureur du Roi v. Dassonville, 1974 E.C.R. 837, 852, 2 C.M.L.R 436, 453-54 (1974); see also supra notes 151-152 and accompanying text.

359. We also saw evidence of this in Van Gend $\mathcal{E}$ Loos with regard to the Court's broad reading of its "interpretive" jurisdiction under EEC Treaty Article 177. See supra note 349. 360. See Case 22/70, Commission v. Council, 197I E.C.R. 263, [1971] C.M.L.R. 335 [hereinafter ERTA].

361. Now EC Treaty art. 71.

362. ERTA, 1971 E.C.R. at 273.

363. Now EC Treaty art. 300. 
mission the exclusive power to negotiate on behalf of the Community. 364 The ECJ sided squarely with the Commission on the question of implied powers, finding not only that the Treaty implicitly granted the Community powers in this domain but that, in view of the need for "the unity of the Common Market and the uniform application of Community law," those powers were in fact exclusive. ${ }^{365}$

With the ERTA decision and its progeny, the European Court of Justice "added another rung in its constitutional ladder."366 It has since become a basic principle of European "constitutionalism" that,

whenever Community law has created for the institutions of the Community powers within its internal system for the purpose of attaining a specific objective, the Community has authority to enter into the international commitments necessary for the attainment of that objective even in the absence of an express provision in that connexion. ${ }^{367}$

Most importantly, in its implied powers decisions, the Court demonstrated that it was willing "to sidestep the presumptive rule of interpretation typical in international law, that treaties must be interpreted in a manner that minimizes encroachment on state sovereignty. The Court favored a teleological, purposive rule drawn from the book of constitutional interpretation." 368

b. Legal Basis. - Decisions like ERTA reflect a more general attitude-the "preference for Europe"-that has become even more apparent as the Court has confronted with increasing regularity challenges to the appropriate legal basis for Community legislation under the Treaty. The legal basis for Community legislation determines the balance of power between the Community and the Member States in three ways. ${ }^{369}$ First, the existence of a legal basis in the Treaty determines whether the power to act has been delegated to the Community or has been retained by the Member States. ${ }^{370}$ Second, the procedural requirements associated with a particular legal basis determine both the degree of political control that any one Member State may assert over the legislative process through the Council, as well as the degree of Commission autonomy in formulating legislative proposals. ${ }^{371}$ Third, the legal basis determines the

364. See EC Treaty art. 300(1) (ex art. 228(1)).

365. ERTA, 1971 E.C.R. at 276 . On the merits, however, the Court held for the Council, finding that the bulk of the negotiations had occurred before the common rules had been adopted. Thus, in those unique circumstances, the Council did not violate Articles 75 and 228. See id. at 281-82.

366. Weiler, Transformation, supra note 31 , at 2416.

367. Opinion 1/76, 1977 E.C.R. 741, 755, [1977] 2 C.M.L.R. 279, 295.

368. Weiler, Transformation, supra note 31 , at 2416.

369. The following discussion draws on Lenaerts, Interaction, supra note 102, at 123.

370. In this sense, ERTA was also a "legal basis" case.

371. That is, by determining the voting scheme in the Council-unanimity, qualified majority or simple majority-as well as the extent of Parliamentary involvementconsultation, cooperation, or co-decision. See id. 123-24. 
nature of the resulting legislative instrument-either a regulation or directive-the first being by definition directly applicable in the Member States and the second requiring, in theory, national implementing legislation. ${ }^{372}$

In legal disputes involving legal basis, the $\mathrm{ECJ}$ has historically favored Treaty interpretations that maximize the prerogatives of those institutions deemed most representative of the Community's interest as a whole: the Court itself, the Commission, and the Parliament. ${ }^{373}$ Take, for example, the issue of justiciability, or whether the Treaty commits the question of the appropriate legal basis to the Council's ultimate discretion or makes it subject to judicial review by the ECJ. The Treaty itself seems to indicate that the question was committed to the Council's discretion. The Council had long argued that it had the right, pursuant to its authority under Article 149(1) of the EEC Treaty to amend proposals from the Commission by a unanimous vote, to determine for itself the appropriate legal basis, regardless of what the Commission had proposed, and free from legal control by the Court. ${ }^{374}$ The Court rejected this argument, ${ }^{375}$ holding that the choice of legal basis is to be determined by "objective factors which are amenable to judicial review."376 In effect, the Court "remove[d] the choice of the correct legal basis from the sphere of political discretion," 377 reserving for itself the role of final arbiter of both the scope of the Community's legislative competence relative to the Member States and the institutional balance within the Community.

4. The Court's Problematic Pursuit of Democratic Values. - As one European judge sympathetic to the Court's approach has noted, however, the Court's "search for 'objective factors'," although designed "to make judicial review more credible," nevertheless is often "open-ended and valueladen." 378 Ironically, the principal value which the Court often claims to be pursuing is democracy, or what the Court has described as "a fundamental democratic principle that the peoples should take part in the exercise of power through the intermediary of a representative assembly." 379 Where more than one provision of the Treaty might arguably

372. See EC Treaty art. 249 (ex art. 189).

373. See generally Lenaerts, Interaction, supra note 102, at 123-28.

374. See Opinion 1/78, International Agreement on Natural Rubber, I979 E.C.R. 2871, 2881, 2906-07, [1979] 3 C.M.L.R. 639, 647, 671. EEC Treaty Article 149(1) provided: "Where, in pursuance of this Treaty, the Council acts on a proposal of the Commission, unanimity shall be required for an act constituting an amendment to that proposal." The TEU transferred this provision to Article 189a(1) (now Article 250).

375. Opinion 1/78, 1979 E.C.R. at 2907-08.

376. Lenaerts, Interaction, supra note 102, at 126 (quoting Case $45 / 86$, Commission v Council, 1987 E.C.R. 1493, 1520, [1988] 2 C.M.L.R. 13I, I53 (1987)).

377. Id. at 125 .

378. Id. at 126.

379. Case C-300/89, Commission v. Council, 1991 E.C.R. I-2867, I-2900, [1993] 3 C.M.L.R. 359, 348-85 (1991) [hereinafter Titanium Dioxide Waste] (tracking language first used in case 138/79, SA Roquette Frères v. Council, 1980 E.C.R. 3333, 3360; and Case 139/ 79, Maizena GmbH v. Council, 1980 E.C.R. 3393, 3424). 
serve as the legal basis for a piece of Community legislation, the Court has expressed its clear preference for the provision requiring the most extensive involvement of the European Parliament-pursuant to either the co-decision or cooperation provisions in Articles 251 and 252 (ex Articles $189 \mathrm{~b}$ and $189 \mathrm{c}$ ).

The Court's approach in this area, however, has often been highly problematic, both as a matter of the Member States' "legislative" intent under the Treaty as well as, more importantly, with respect to the pursuit of democratic legitimacy strictly speaking. The decision in which the Court first applied the "fundamental democratic principle" to the question of legal basis is instructive. The case arose out of a dispute between the Commission and the Council over the passage of a directive on titanium dioxide waste. ${ }^{380}$ The Commission based its proposal on EEC Treaty Article $100 \mathrm{a}^{381}$ (added to the Treaty by the Single European Act of 1986) which governed the adoption of harmonization directives designed to achieve the internal market. Under the SEA, Article 100a of the EEC Treaty authorized passage of internal market directives by a qualified majority in the Council, followed by the "cooperation" procedure in the Parliament. ${ }^{382}$ The Council argued, however, that given its subject matter the directive should have been based on EEC Treaty Article 130s (also introduced into the Treaty by the SEA), which governed the adoption of environmental directives. ${ }^{383}$ EEC Treaty Article 130 s authorized passage only after a unanimous vote in the Council, and then merely "in consultation" with the Parliament. 384

Clearly, the Single European Act created some ambiguity with regard to the appropriate legal basis for environmental legislation. On the one hand, EEC Treaty Article 100a(3) expressly contemplated the adoption of environmental protection directives in order to achieve the internal market. ${ }^{385}$ Yet, the presence of a more specific provision for the adoption of environmental legislation in EEG Treaty Article 130s provides at least prima facie evidence of the Member States' intent to exercise greater control over the content of such legislation, via unanimity in the Council. Once the Court concluded that EEC. Treaty Article 130s was an appropriate legal basis, ${ }^{386}$ according to venerable canons of legislative interpretation prevailing in code-based countries, the more specific provi-

380. See Titanium Dioxide Waste, 1991 E.C.R. at I-2900.

381. Now EC Treaty art. 95.

382. "Cooperation" refers to the procedure now codified at Article 252 (ex art. 189c), which in effect provides the Parhament with a suspensive veto that can be overridden only by a unanimous vote in the Council. In the TEU, the Member States again amended Article 95 (ex art. 100a) to require Parliamentary co-decision under Article 251 (ex art. $189 \mathrm{~b})$, which gives the Parliament a true veto over proposed legislation.

383. EC Treaty Article 175 (ex art. 130s).

384. See EEC Treaty art. 130s. EC Treaty art. 175 (ex art. 130s) now requires codecision under Article 251.

385. EC Treaty art. 95(5).

386. See Titanium Dioxide Waste, 1991 E.C.R. at I-2899-2901. 
sion should have trumped the more general. The Court, however, used its "fundamental democratic principle" as an aid in tipping the balance in favor of the opposite conclusion, resolving the ambiguity against the Council, contrary to the arguable intent of the Member States. ${ }^{387}$

Despite the Court's professed pursuit of democratic values, the reasoning in Titanium Dioxide Waste is deeply questionable on democratic legitimacy grounds for at least two reasons. First, it is unclear which institution-the Parliament or the Commission-actually benefitted most from the Court's ruling. By favoring the cooperation procedure, the Court not only increased the involvement of the Parliament but also expanded the freedom of action of the Commission from Member State control, because the cooperation procedure only requires qualified-ma-

387. The Court ultimately based its judgment on the so-called "center of gravity" test, finding that the Titanium Dioxide Waste Directive was centered primarily on harmonizing national rules on production in an industrial sector so as to eliminate competitive distortions, rendering Article 100a the appropriate legal basis. Id. at I-2901, para. 23. The Court further claimed that, because EEC Treaty Article 130r(2) provided that "[e]nvironmental protection requirements shall be a component of the Community's other policies," this implied that "a Community measure does not necessarily call for the application of Article 130s simply becuase it pursues environmental objectives." Id., para. 22. However, further evidence of the intent of the Member States to maintain the maximum degree of control over environmental legislation is found in EEC Treaty Article 130r, which introduced the subsidiarity principle into the Treaty specifically in the environmental domain (the principle would be added to the Treaty generally as Article $3 \mathrm{~b}$ by the TEU in 1992). See EC Treaty art. 5 . As will be argued in greater detail below, see infra notes $459-466$ and accompanying text, subsidiarity should be regarded as an interpretive principle favoring constructions of the Treaty that maximize Member State control. Given the specific insertion of the subsidiarity principle in the environmental domain in EEC Treaty Article 130r, the appropriate choice of legal basis in this case slould have been one that required unanimity in the Council-i.e., EEC Treaty Article 130s.

In a more recent decision, Case C-155/91, Commission v. Council, 1993 E.C.R. I-939, [1993] 68(7) C.M.L.R. 359 [hereinafter Waste Directive], the Court took a stricter line, specifically with regard to a 1991 annendinent to a 1975 directive on waste disposal, holding that the appropriate legal basis was EEC Treaty Article 130s and not Article 100a, as the Commission had proposed. On the directive's "center of gravity," the Court reasoned that the waste directive amendinent was aimed prinarily at "protecting the environment" and had "only ancillary effects on the conditions of coinpetition and trade." Id. at I-968-69. The Court distinguished its earlier decision on the titanium waste directive by virtue of its purported restriction to "a given industrial sector with the aim of eliminating distortions of competition in that sector," so that it constituted a harmonization/internal market directive under EEC Treaty Article 100a. Id. at I-969. This is at best a distinction without a difference. The fact that the waste directive amendinent applied to all waste rather than to a specific type does not alter the fact that different producers in different Member States might be subject to different regulatory regimes with effects on the conditions of competition and trade. Indeed, the origimal waste directive had been adopted in 1975 as a harmonization/internal market directive under EEC Treaty Articles 100 and 235, in the era when the Court was expansively interpreting the Community's competence under those provisions. See supra notes 154-156 and accompanying text. Perhaps the only explanation for the Court's changed attitude in 1993, when it handed down its decision on the waste directive amendinent, is that it reflects increased caution on the part of the Court following the surprising popular opposition to the ratification of the TEU in 1992. On the Court's changed attitude after 1992, see infra notes 398-405 and accoinpanying text. 
jority voting in the Council. ${ }^{388}$ Indeed, given what some see as the Parliament's effective exclusion from the real process of decisionmaking in any case-regardless of the type of legislative procedure used ${ }^{389}$ - one could fairly hypothesize that the principal effect of the Court's decision was to solidify the position of the Community's permanent bureaucracy vis-à-vis the Council and the Member States.

There is a second, even more fundamental democratic legitimacy criticism, which relates to the ECJ's problematic invocation of the notion of the democratic rights of the European "peoples" taken together. As Part IV of this article argued in great detail, no European demos yet exists as a cultural reality, and as long as this is the case, the European Parliament cannot claim the democratic legitimacy that national parliaments presently possess as representatives of their respective national communities. To make such a claim on behalf of the European "peoples" aggregated as a whole, and to use this claim to presume a greater degree of democratic legitimacy in the Parliament than in the Council, is effectively to argue that some form of European demos already exists. Although the development of a European demos is not out of the question-indeed, evidence now exists that the cultural foundations for such a demos are being laid-its emergence will require a major transformation: As Joseph Weiler rightly put it, "[i]ndividuals must think of themselves in this way before such a demos could have full legitimate democratic authority." 390 Because national identity still predominates over European identity, ${ }^{391}$ the Court's reference to a "fundamental democratic principle" simply shows that it mistakenly equates formal parliamentary democratization at the Community level with true democratic legitimacy.

The likely consequence of its legal basis decisions is the consolidation of the formal autonomy of the Community's normative power from the democratically legitimate political structures of the Member States. The constitutionalist "preference for Europe"-along with the teleological method of Treaty interpretation that the Court has used to translate that preference into legal terms-has amounted in practice to a strong presumption in favor of the prerogatives of the Community. At least until 1992, when the legal and political debates over the ratification of the TEU brought the question of the democratic deficit squarely to the fore, it was apparently of little consequence to the Court that the Community's

388. On the relationship between qualified-majority voting and Commission autonomy, see supra notes 165-166 and accompanying text.

389. See Weiler, Demos, supra note 28, at 233-34. On a related point, Professor Majone states that most of the decisions are made by the Commission before an issue reaches even the Council. See Majone, Regulatory State, supra note 55, at 92. He further notes that the advent of qualified-majority voting undermines the power of the Member States to bring political considerations to bear in the legislative process. See id.

390. Weiler, Demos, supra note 28 , at 254.

391. See generally Deflem \& Pampel, supra note 61; Shore, supra note 61; Wood, supra note 61. 
popular legitimacy was at best questionable when compared to that of the Member States.

5. Signs of Restraint After 1992. - The democratic deficit became an unavoidable issue following the expansion of the Community's autonomous legislative powers in the SEA of 1986 and then in the TEU of 1992. Perhaps not surprisingly, given the expressed intent of the Member States to reassert some measure of political control over the Community's norm production, ${ }^{392}$ certain judges on the Court began to query publicly whether the time had come for a more restrained stance vis-à-vis the political process. Some observers saw signs of "public penance" in the statements of members of the Court in the early 1980s as intended "to reassure concerned onlookers that the Court was very well aware of the need for prudence." 393 However, at least before the political crises that accompanied the ratification of the TEU in 1992, the tenor of many judges' public statements reflected more pride than penance in what the Court had been able to accomplish to date, guiding the Community through the long night of Eurosclerosis until the moment when the political process was finally able to regain "the strength to make policy decisions and pass necessary legislation." 394

Indeed, between 1986 and 1992, a strong sense of "Euro-optimism" prevailed, and the public statements of members of the Court arguably reflected this outlook. The Single European Act had removed the most serious obstacle to supranational legislation by instituting qualified-majority voting in the Council in most important matters, notably the achievement of the internal market, and had also increased Parliamentary involvement through the introduction of the cooperation procedure. The Community was now actively pursuing the goal of achieving the internal market by 1992, delegating extensive normative powers to the Commission to achieve this task. ${ }^{395}$ In these circumstances, some measure of judicial self-restraint seemed to be appropriate because the political process now appeared ready to pursue vigorously the telos of the Community as the Court understood it. As Judge Mancini declared in a speech at Harvard in late 1989, "[w] hen democracy advances and politics asserts its claims, judges are bound to take a pace back."396 Although Judge Mancini acknowledged that some would call this "a retreat from the daring of old," he preferred to describe it simply as "a little rest, all the more pleasant for being so richly deserved." 397

392. See Lenaerts, Interaction, supra note 102, at 110-11.

393. Burley \& Mattli, supra note 100, at 71 (referring to articles by Judge Ulrich Everling in the early 1980s).

394. Lenaerts, Interaction, supra note 102, at 95.

395. See supra notes 159-162, 283-284 and accompanying text.

396. Mancini, supra note 102, at 613. Judge Mancini went on to say: "The Court still has ample room to mould [sic] the destiny of the Community both by writing new rules and by cutting a number of Gordian knots." ld. at 614 .

397. Id. at 614 . 
The post-1992 environment lacked much of the optimism of the 1986-1992 period. The depth of popular opposition to the Maastricht Treaty (the TEU) caught many ardent supporters of European integration by surprise. ${ }^{398}$ The self-assurance of Judge Mancini in $1989^{399}$ now seemed decidedly out of place, belied not only by the ratification crises of 1992, but also by the intent of the drafters of the TEU to place clear limits on the jurisdiction of the ECJ through the pillar structure of the newlyestablished European Union. ${ }^{400}$ Although Judge Mancini could confidently declare in 1989 that "[a]ccepting a measure of self-restraint . . . does not mean embarking on a course of strict constructionism," 401 several post-1992 decisions seemed to indicate that the Court was prepared to pursue precisely such a course. In 1993 and 1994, the Court handed down major decisions reflecting unexpectedly restrictive interpretations of Community competence in two key areas: the free movement of goods $^{402}$ and the Community's implied powers in external affairs. ${ }^{403}$

398. See The Ratification of the Maastricht Treaty, supra note 29, at 3-4; see also David Arter, The Politics of European Integration in the Twentieth Century 212-16 (1993).

399. See Mancini, supra note 102, at 613 (contemplating that, although the Court was "likely to extend the area of problems which it feels should be solved by the political institutions, ... in other areas it [would] undoubtedly go on feeling that it can, or rather must, exercise guidance").

400. See TEU art. 46 (ex art. L); supra text accompanying note 178. According to Weiler and Trachtman: "It is clear that the principal raison d'être of the pillar structure, with the meticulous and explicit attempt to exclude the Court, was the wish of the Member States to operate outside the European constitutional structure." Weiler \& Trachtman, supra note 23 , at 371 .

401. Mancini, supra note 102 , at 613.

402. See Joined Cases 267 and 268/91, Keck and Mithouard, 1993 E.C.R. I-6097 (partially overturning Dassonville, 1974 E.C.R. 837, which held that a showing of potential and indirect hindrance to interstate trade was sufficient to strike down a Member State requirement under Article 30). According to Keck, the Dassonville rule does not apply to so-called "selling arrangements" (i.e., marketing standards) as long as those standards "apply to all affected traders operating within the national territory." Id. at I-6131. This decision has provoked considerable commentary, often strongly negative. See, e.g., Laurence W. Gormley, Reasoning Renounced? The Remarkable Judgment in Keck \& Mithouard, 5 Eur. Bus. L. Rev..63 (1994). According to Weiler and Trachtman: "[I]f one finds a certain emotional edge in the articles dealing with decisions of the European Court in cases such as Keck and others like it, this is understandable. These decisions are painful since they seem like a betrayal [of the constitutionalist vision] from within the Vatican itself [i.e., the ECJ]." Weiler \& Trachtman, supra note 23, at 371-72.

403. See Opinion 1/94, 1994 E.C.R. I-5267, I-5281-5344 (re the WTO Agreement) (holding the Community and the Member States had concurrent competence to ratify the General Agreement on Trade in Services (GATS) and the Agreement on Trade-Related Aspects of Intellectual Property Rights (TRIPs)). The Commission had argued for the Community's exclusive competence, first, based on the purported inclusion of trade in services and intellectual property rights within the scope of the Community's common commercial policy under Article 113, and, alternatively, because of their inclusion withm the Community's exclusive implied powers under the ERTA doctrine. See id. at I-5282-83. The Court rejected both arguments, motivated apparently by the concern that recoguition of exclusive Community competence would circumvent the Community's internal 
One suspects that the difficulties associated with the ratification of the Maastricht Treaty, which revealed a decided lack of popular consensus over the direction of European integration in several Member States, had much to do with blunting the Court's enthusiasm for its earlier activism. ${ }^{404}$ These decisions certainly indicate a willingness on the part of the Court to take a more respectful line toward Member State prerogatives. ${ }^{405}$

\section{The Persistence of the "Preference for Europe" in the Emerging Case Law on Subsidiarity}

The free movement of goods and implied powers decisions noted above $^{406}$ undoubtedly signal a change in course. It would, however, be wrong to conclude that they reflect a fundamental abandonment of the Court's broad interpretation of the Community's legislative powers, as though the Council and Parliament were a "normal" or "constitutional" legislature drawing their legitimacy directly from a definable European "people." The persistence of the constitutionalist "preference for Europe" manifests itself most clearly in the degree of deference the Court is prepared to show the Community "legislature" on questions involving the application of the principle of subsidiarity. ${ }^{407}$ Deference in this context is especially problematic because the Member States' aim in inserting the principle into the Treaty alongside enumerated powers and proportionality was clearly to constrain the exercise of the Community's newlyexpanded legislative authority after 1992.408

harmonization procedures and would be unnecessarily disruptive of the existing division of competences between the Member States and Community. See Piet Van Nuffel, Case Law: WTO-Agreement, 1 Colum. J. Eur. L. 338, 348, 351 (1995).

404. The Court's apparent change in course after 1992 might bear out the positive political theory of judicial behavior developed by McCubbins, Noll, and Weingast in the American context. See McNollgast, Politics and the Courts: A Positive Theory of Judicial Doctrine and the Rule of Law, 68 S. Cal. L. Rev. 1131 (1995). They find that, although routine electoral vicissitudes generally do not affect the content of judicial doctrine as announced by the Supreme Court, doctrine has been highly responsive to major electoral shocks (e.g., post-1932). See id. at 1152-56, 1168-73. In the European case, perhaps 1992 was precisely such a shock, which the ECJ could simply not ignore.

405. In addition to Keck and Mithouard, 1993 E.C.R. I-6097, and Opimion 1/94, 1994 E.C.R. I-5281, see Waste Directive 1993 E.C.R. I-939, I-964-70, [1993] 68(7) C.M.L.R. 359. For a similar view, see Todd J. Friedbacber, Motive Unmasked: The European Court of Justice, the Free Movement of Goods, and the Search for Legitimacy, 2 Eur. L.J. 226 (1996) (claiming that the Court was motivated in these case by a sense of wanimg faith in its institutional legitimacy).

406. See supra notes $402-403$.

407. See Working Time Directive, 1996 E.C.R. I-5755, I-5793, [1996] 3 C.M.L.R. 671; Case C-233/94, Germany v. Parliament and Council, 1997 E.C.R. I-2405, I-2441, [1997] 3 C.M.L.R. 1379 [hereinafter Deposit-Guarantee Schemes]. On the principle of subsidiarity in Article 5 (ex Article 3b) of the EC Treaty, see supra notes 170-175 and accompanying text.

408. George Bermann notes: "As if to emphasize the connection between subsidiarity and the expansion of the Community's powers, the drafters of the TEU put language into virtually every new treaty chapter underscoring their intention that the Member States 
1. Preliminary Considerations: Comparing the Deference Owed a Constitutional Legislature and an Administrative Agency. - A constitutional legislature, as that term is used in this Article, exercises legislative power delegated directly from the people, and is further subject to direct and periodic popular control by way of the vote. ${ }^{409}$ Given the popular source of its legislative powers and legitimacy, courts are generally reluctant to oblige a constitutional legislature to articulate in detail its reasons for adopting a particular law. Rather, courts defer to the policy choices of a constitutional legislature as long as there is some identifiable rational basis for the legislature's decision. ${ }^{410}$ Broad deference is justified because it is ultimately the responsibility of the voters to approve or disapprove of the advisedness of legislative action. Except in the rare instance when the legislature oversteps the bounds of its constitutional authority or violates the constitutional rights of an individual, it is not for a judge to intervene.

The direct democratic check that exists in the constitutional legislative context does not exist in the administrative context, which undermines-though hardly eliminates-the case for deference to agency policy choices. Judges should not substitute their policy preferences for those of an administrative agency if that agency is lawfully operating within the bounds of its delegated authority. ${ }^{411}$ As the French put it, the role of the administrative judge is to consider questions of la légalité (legality), not those of l'opportunite (that is, the political expediency of making a particular decision or adopting a particular rule). ${ }^{412}$ Yet, the enforcement of legality in the administrative context often leads courts to invade the realm of agency policymaking to a degree not appropriate

continue to exercise primary responsibility in these new Community spheres." Bermann, Taking Subsidiarity Seriously, supra note 48, at 346; see also Marquardt, Subsidiarity, supra note 172 , at $625-27$.

409. See supra note 65 and accompanying text.

410. See, e.g., United States R.R. Retirement Bd. v. Fritz, 449 U.S. 166, 179 (1980) ("Where, as here, there are plausible reasons for Congress' action, our inquiry is at an end. ... [T] [Tis Court has never insisted that a legislative body articulate its reasons for enacting a statute."). As the ECJ puts it: "[I]t would be pointless to require [that the legislature provide] a specific statement of reasons for each of the technical choices made by it." Working Time Directive, 1996 E.C.R. at I-5816.

41I. The Supreme Court in Cheoron stressed this point quite clearly: "When a challenge to an agency construction of a statutory provision, fairly conceptualized, really centers on the wisdom of the agency's policy, rather than whether it is a reasonable choice within a gap left by Congress, the challenge must fail. In such a case, federal judges - who have no constituency - have a duty to respect legitimate policy choices made by those who do." Chevron U.S.A., Inc. v. Natural Resources Defense Council, Inc., 467 U.S. 837, 866 (1984).

412. Despite the broad deference that the ECJ shows, this is precisely the terminology that it uses to describe its role: "[I]t is not the function of the Court to review the expediency of measures adopted by the legislature. The review [of Community legislation] must be limited to the legality of the disputed measure." Working Time Directive, 1996 E.C.R. at I-5802. However, while the Court's legality/expediency terminology reflects the influence of French administrative law, its "constitutionalist" stance is behed by its persistent invocation of the term "legislature." 
when dealing with a legislature-for example, through more stringent applications of the principles of proportionality and cost-benefit analysis. This tendency toward more searching judicial review in the administrative context is justified, from a democratic legitimacy standpoint, by the often problematic nature of hierarchical political control over delegated normative power by elected representatives. ${ }^{413}$ Unchecked administrative discretion, beyond political or even legal control, violates the democratic principle by conferring autonomous normative power on unaccountable technocrats.

In the administrative context, therefore, a reviewing court promotes democratic legitimacy when it forces the agency, as an aspect of legality, to give sufficient reasons for its actions in order to demonstrate that the agency has engaged in "reasoned decisionmaking." ${ }^{414}$ A court evaluating the legality of administrative action must not simply accept conclusory statements from the agency justifying its actions. Rather, the reviewing court must satisfy itself that the agency "examine [d] the relevant data and articulate[d] a satisfactory explanation" for its normative output. 415 If the agency cannot make such a showing, the court should annul the challenged measure and remand the question to the agency for reconsideration. Americans describe this more demanding level of scrutiny of administrative action as "hard look" review. .16

2. Deference to Conclusory Findings of the Community "Legislature" on Questions of Subsidiarity. - There have been two post-1992 cases that have raised serious issues of subsidiarity.417 In each, the Court rejected demands by the complaining Member States that the Court engage in a kind of "hard look" review of the evidence purportedly demonstrating why Community action was preferable to rulemaking at the national or sub-national level. In the first case, the Court simply inferred, in the absence of any evidence, that the requirements of subsidiarity were satisfied solely by virtue of the Council's decision to legislate. ${ }^{418}$ In the second,

413. See Lindseth, Comparing Administrative States, supra note 73, at 618 (speaking of the greater burden on the courts to supervise the fairness and legitimacy of administrative decisionmaking in the absence of adequate political controls).

414. Greater Boston Television Corp. v. FCC, 444 F.2d 841, 851 (D.C. Cir. 1970) (footnote omitted), cert. denied, 403 U.S. 923 (1971) (describing "hard look" review). In Motor Vehicle Mfr. Ass'n v. State Farm Mut. Auto. Ins. Co., 463 U.S. 29 (1983), the Supreme Court "essentially endorsed 'hard look' review." Peter L. Strauss, Considering Political Alternatives to "Hard Look" Review, 1989 Duke L.J. 538, 539 [hereinafter Strauss, "Hard Look" Review].

415. State Farm, 463 U.S. at 43.

416. See, e.g., Strauss, "Hard Look" Review, supra note 414; see also Strauss, From Expertise to Politics, supra note 63, at 756-57 (explaining, inter alia, how "hard look" review developed as an interpretation of the APA).

417. See Working Time Directive, E.C.R. I-5755, [1996] 3 C.M.L.R. 671; DepositGuarantee Schemes, 1997 E.C.R. I-2405, [1997] 3 C.M.L.R. 1379.

418. See infra note 426 and accompanying text. 
the Court accepted conclusory statements contained in legislative recitals as a sufficient basis to justify action at the Community level. ${ }^{419}$

The first decision arose out of a challenge by the United Kingdom to the so-called "Working Time Directive," 420 which, inter alia, requires the Member States to enact legislation limiting the work week to an average maximum of 48 hours and mandating four weeks of paid vacation per worker each year. ${ }^{421}$ The measure was adopted in 1993 by a qualified majority pursuant to then-Article 118 a (added to the Treaty by the SEA in 1986), which authorized harmonization directives establishing "minimum requirements" regarding the "working environment," as well as "the health and safety of workers." 422 The then-Conservative British government opposed the measure in the Council and ultimately abstained from its adoption. ${ }^{423}$

In its application to the Court, Britain argued that the directive, aside from being unsupported by any scientific evidence linking the new work rules with its purported "health and safety" objectives, failed to disclose why those objectives would better be achieved by action at the Community level rather than at the national level.424 In its decision, the Court made no explicit ruling that the Council was under any obligation to explain how the directive satisfied the subsidiarity requirements of thenArticle 3b. ${ }^{425}$ The Court focused instead on the language of Article 118a, which in the Court's reading recoguized "harmonization" as an end in itself - rather than a means to the end of "health and safety" -in seeming contradiction of the subsidiarity principle. In response to the United

419. See infra notes $428-431$ and accompanying text.

420. Council Directive 93/104 concerning certain aspects of the organisation of working time, 1993 O.J. (L 307) 18 [hereinafter Working Time Directive].

421. More specifically, the Working Time Directive obligates the Member States to take the measures necessary to ensure that every worker is entitled to a minimum daily rest period of 11 consecutive hours per 24 hour period (Article 3); to a rest break where the working day is longer than six hours, the details of such break to be determined by the two sides of industry or by national legislation (Article 4); to a minimum uninterrupted rest period of 24 hours in each seven-day period, plus the 11 hours daily rest referred to in Article 3 (Article 5, first sentence); such period in principle to include Sunday (Article 5, second sentence); and, finally, to four weeks paid annual leave (Article 7). See id.

422. For the text of Article 118a of the EC Treaty, as amended by the TEU, prior to the entry into force of the Treaty of Amsterdam, see 1992 O.J. (C 224) 45. Article 2(22) of the Treaty of Amsterdam replaced Articles 117-120 of the EC Treaty, as amended by the TEU; see EC Treaty arts. 136-143, as amended by the Treaty of Amsterdam, 1997 O.J. (C 340) 239-43. The new Treaty provisions incorporate the Protocol and Agreement on Social Policy attached to the TEU, 1992 O.J. (C 224) 126-29, from which the United Kingdom had opted out.

423. The United Kingdom argued that the true purpose of the Directive was to create jobs and reduce unemployment and for that reason constituted a misuse of powers under Article 173. See Working Time Directive, 1996 E.C.R. I-5755, I-5763, para. 26, [1996] 3 C.M.L.R. 671 (Opinion of Advocate-General Philippe Léger) (citing sections 3.12 and 3.13 of the United Kingdom application).

424. See id. at I-5782-83, para. 122.

425. EC Treaty art. 5 . 
Kingdom's subsidiarity argument, the Court resorted to a tautology: "Once the Council has found that it is necessary to improve the existing level of protection as regards the health and safety of workers and to harmonise the conditions in this area ..., achievement of that objective through the imposition of minimum requirements necessarily presupposes Community-wide action . . .."426

In the second case, the Court's treatment of a similar challenge by Germany to the adoption of a directive requiring the establishment of "deposit guarantee systems" in credit institutions was only slightly more rigorous. ${ }^{427}$ The Court relied exclusively on conclusory statements contained in the directive's recitals to find, somewhat sweepingly, that "the Parliament and the Council did explain why they considered that their action was in conformity with the principle of subsidiarity." 428 The Court looked particularly to the second recital in the preamble to the Directive that "consideration should be given to the situation that might arise if deposits in a credit institution that has branches in other Member States became unavailable" and that it was "indispensable to ensure a harmonized minimum level of deposit protection wherever the deposits are located in the Community." 429 The Court also noted that, as the fifth recital indicated, the action taken by the Member States in response to an earlier Commission recommendation "had not achieved the desired result." 430 According to this reasoning, George Bermann and others have noted, "it is sufficient for the institutions merely to reach and to state a conclusion on the subsidiarity question; they do not apparently have to recite detailed evidence to support that conclusion-much less convince the Court that the conclusion is correct." 431

426. Working Time Directive, 1996 E.C.R. at I-5809, para. 47 (emphasis added).

427. Deposit-Guarantee Schemes, 1997 E.C.R. I-2405, I-2411 [1997] 3 C.M.L.R. 1379, 1383-84.

428. Id. at 1-2453, para. 28. One explanation for the perfunctory nature of the Court's treatment of the subsidiarity issue in Deposit-Guarantee Schemes is that it reflects the way in which counsel for the Federal Republic of Germany presented the subsidiarity argument to the Court. German counsel argued subsidiarity as part of the requirement to provide reasons under then-Article 190 (now Article 253), rather than as a substantive claim to annul the directive. (I am grateful to Stephan Wernicke for this insight.) From an American standpoimt, however, it is difficult to see how the presentation of the subsidiarity argument as part of a claim under Article 190 should relieve the Court from a full treatment of Germany's position, particularly as it relates to the procedural obhigations on the part of the Community "legislature" to evaluate the subsidiarity aspects of the proposed directive. On the procedural dimension of subsidiarity viewed from an American perspective, see Bermann, Taking Subsidiarity Seriously, supra note 48, at 391. In effect, I am arguing for a kind of "hard look" doctrine on questions of subsidiarity. On the American "hard look" doctrine, see supra notes 414-416 and accompanying text.

429. Deposit-Guarantee Schemes, 1997 E.C.R. at I-2452, para. 26.

430. Id. at I-2452, para. 27.

431. 1998 Supplement to Cases and Materials on European Community Law (Including European Union Materials) 23 (George A. Bermann et al. eds., 1998). Indeed, the Court has stated quite clearly that the authority to adopt a harmonization directive "cannot be limited exclusively to circumstances where the justification for such action is 
The Court's refusal to engage in more searching judicial review on questions of subsidiarity effectively imputes a rational basis to the Community's interpretation of the scope of its legislative power in the absence of any supporting evidence. This highly deferential approach would perhaps be justified if the Council and the Parliament possessed the democratic legitimacy of a constitutional legislature, subject to direct popular control, which of course they do not. Indeed, several Member States, among them France, Germany, and the United Kingdom, found the Court's position sufficiently objectionable that they demanded the insertion of a judicially enforceable "Subsidiarity Protocol" in the new Treaty of Amsterdam of 1997.432 This Protocol provides, in pertinent part, that "[f]or any proposed Community legislation, the reasons on which it is based shall be stated with a view to justifying that its compliance with the principles of subsidiarity and proportionality." 433 It further states that "the reasons for concluding that a Community objective can be better achieved by the Community must be substantiated by qualitative or, wherever possible, quantitative indicators." 434 By placing this evidentiary burden on

scientifically demonstrated." Working Time Directive, 1996 E.C.R. at I-5806, para. 39. In arriving at this conclusion, the Court made an implicit distinction between the Council as a "legislative" body and the Commission as an "administrative" body. The Court had ruled in an earlier case that all subordinate legislation adopted by Commission action must be "founded on scientific and technical assessments which must themselves be based on the results of the latest international researcb." See supra notes 302-304 and accompanying text (discussing Case 12/91, Angelopharm GmbH v. Freie und Hansestadt Hamburg, 1993 E.C.R. I-171). Indeed, the Court went so far as to say that technical and scientific consultation on the part of the Commission was required by "the nature of things and apart from any provision laid down to that effect." Angelopharm, 1993 E.C.R. at I-211. However, in the case of the Working Time Directive, apart from the requirement of eleven hours rest per work day (where sonre research existed), the Council offered no scientific evidence to support the health and safety claims for the directive's other work rules (rest breaks during the work day, a day of rest on Sunday, a limitation of the average work week to 48 hours, and four weeks paid vacation). See Working Time Directive, 1996 E.C.R. at I5804, para. 32. In fact, the Council did not even bother to consult the Advisory Committee on Safety, Hygiene and Health Protection at Work in the drafting of the directive. See id. at I-5806, para. 39. The Court of Justice held, however, that such consultation was mandatory only for the Commission, and that the Council's "failure to consult [the Advisory Committee] cannot be relied on to cast doubt on the link between the measures laid down by the directive and the protection of health and safety of workers." Id. at I-5807.

432. Treaty of Amsterdam, Protocol on the application of the principles of subsidiarity and proportionality, 1997 O.J. (C 340) 105 [heremafter Subsidiarity Protocol].

433. Id. at para. 4.

434. Id. (emphasis added). Paragraph 5 also specifies that both aspects of the subsidiarity principle must be met: (1) that "the objectives of the proposed action cannot be sufficiently achieved by Member States' action in the framework of their national constitutional system," and (2) that those objectives "can therefore be better achieved by action of the part of the Community." Id. The Protocol further codified the subsidiarity 'guidelines' issued at the 1992 Edinburgh Summit by the European Council (the heads of state or government of the various Member States), requiring all Community imstitutions to deternnine: (I) whether the problem to be addressed "has transnational aspects which cannot be satisfactorily regulated by action by Member States"; (2) whether the Community's failure to act "would conflict with the requirements of the Treaty (such as the 
the Community's "legislature," the Member States signaled to the Court that it should no longer defer so sweepingly to legislative policy choices that are at least questionable on subsidiarity and proportionality grounds. Rather, the Member States have now instructed the Court to evaluate the Council's and the Parliament's reasoning on these critical questions in the same manner and to the same extent as one might expect of a national court exercising a kind of "hard look" review over administrative decisionmaking. ${ }^{435}$

As George Bermann has argned in terms consistent with the administrative perspective advanced here, subsidiarity is both a procedural and a substantive constraint on Community lawmaking. ${ }^{436}$ In fact, according to Professor Bermann, the principle is perhaps best understood in procedural terms, obligating the ECJ "to verify whether the institutions themselves examined the possibility of alternative remedies at or below the Member State level." ${ }^{\text {437 }}$ On the one hand, the Court should avoid "enmeshing itself in profoundly political judgments that it is ill-equipped to make and ultimately not responsible for making." 438 On the other hand, the Court must force the Council, the Commission, and the Parliament "to structure their discussion and focus their debate" specifically on questions of subsidiarity, which in turn "should promote a realistic assessment ... of the costs and benefits of Community action and inaction alike."439

3. The Rejection of Subsidiarity as an Interpretive Principle. - Emphasizing the procedural aspects of the subsidiarity principle does not mean that its substantive dimension should be ignored. Indeed, part of the explanation for the Court's cursory treatment of subsidiarity as a procedural norm is to be found in its highly mechanistic understanding of the substantive relationship between subsidiarity and proportionality, the other major constraint on Community lawmaking in Article 5 (ex Article $3 \mathrm{~b}$ ) of the EC Treaty. ${ }^{440}$ In the Working Time Directive case, for example, the United Kingdom had argued quite reasonably that "a measure will be

need to correct distortion of competition or avoid disguised restrictions on trade or strengthen economic and social cohesion) or would otherwise significantly damage Member States' interests"; and (3) whether the proposed measure "would produce clear benefits by reason of its scale or effects compared with action at the level of the Meinber States." Edinburgh European Council, Dec. 11-12, 1992, Bull. EC 12-1992, No. 12, vol. 25 (summarizing results of the Edinburgh Summit). For a critique of the guidelines, see Bermann, Taking Subsidiarity Seriously, supra note 48, 368-71.

435. On the American "hard look" doctrine, see supra notes $414-416$ and accompanying text.

436. See Bermann, Taking Subsidiarity Seriously, supra note 48, at 391.

437. Id.

438. Id.

439. Id.

440. Article 5 (ex art. $3 \mathrm{~b}$ ) of the EC Treaty provides, with regard to proportionality, that "[a]ny action by the Community shall not go beyond what is necessary to achieve the objectives of this Treaty." 
proportionate only if it is consistent with the principle of subsidiarity"441 and that the nature of the Community's legislative authority under thenArticle 118a "should be interpreted in the light of the principle of subsidiarity." 442 The Court squarely rejected this effort to merge the two concepts, holding that subsidiarity is only relevant on the functional question of "the need for Community action" rather than on the manner of its exercise. ${ }^{443}$ The Court further stated that " $[t]$ here is nothing in the wording of Article 118a to indicate that [its provisions] should, in the absence of other indications, be interpreted restrictively." 444 The existence of the subsidiarity principle in the Treaty apparently did not constitute one of those "other indications."

Admittedly, the Court's approach was consistent with the opinion of the Advocate-General as well as with a large body of scholarly commentary, which view the question of subsidiarity as strictly one of competence that is distinct from the appropriate extent of otherwise lawfully exercised Community power. ${ }^{445}$ This interpretation also finds some support in the actual language of Article 5 (ex Article 3b), which identifies the central question as whether "the objectives of the proposed action cannot be sufficiently achieved by the Member States and can therefore, by reason of the scale or effects of the proposed action, be better achieved by the Community." ${ }^{46}$ As one commentator has noted, "the underlying logic of [Article 5's language] reduces the claim of rightful governance to a technocratic question of functional efficiency." 447 Subsidiarity, in this narrow, technocratic reading of Article 5, "determines whether Community action is to be set in motion," whereas the proportionality principle "'defines its scope." "448

One might question whether this doctrinal interpretation of the relationship between subsidiarity and proportionality can survive the Subsidiarity Protocol attached to the Treaty of Amsterdam. Section 3 of the Protocol indicates that " $[t]$ he principle of subsidiarity provides a guide as

441. Working Time Directive, 1996 E.C.R. I-5755, 1-5810, para. 54, [1996] 3 C.M.L.R. 671,718 , para. 54 .

442. Id. at I-5808, para. 46, [1996] 3 C.M.L.R. at 717; para. 46.

443. Id. at I-5811, para. 55, [1996] 3 C.M.L.R. at 718, para. 55 (emphasis added).

444. Id. at I-5800, para. 15, [1996] 3 C.M.L.R. at 710, para. 15.

445. Id. at I-5783, para. 126, [1996] 3 C.M.I.R. at 699, para. 126 (Opinion of Advocate-General Léger) (citing $\mathrm{K}$ Lenaerts \& $\mathrm{P}$ van Ypersele: "Le principe de subsidiarité et son contexte: étude de l'article 3 B du Traité CE," (1994) 1-2 Cahiers de Droit Européen 3 (para 100); G Strozzi: "Le principe de subsidiarité dans la perspective de l'intégration européenne: une énigme et beaucoup d'attentes," (1994) 30(3) Revue Trimestrielle de Droit Européen 373)).

446. EC Treaty art. 5.

447. Marquardt, Subsidiarity, supra note 172, at 618 .

448. Working Time Directive, 1996 E.C.R. at I-5783, para. 126, [1996] 3 C.M.L.R. at 699, para. 126 (Opinion of Advocate-General Léger) (quoting $K$ Lenaerts and $P$ van Ypersele: "Le principe de subsidiarité et son contexte: étude de l'article $3 \mathrm{~B}$ du Traité $\mathrm{CE}$," (1994) 1-2 Cahiers de Droit Européen 3 (para 100)). 
to how [the Community's] powers are to be exercised . . . "449 This language would seem to indicate that subsidiarity does in fact relate to the manner in which the Community exercises its powers. It further seems to confirm the position of George Bermann that the principles of subsidiarity and proportionality "bear a much more awkward relationship to each other than is commonly supposed." 450 Indeed the English text of Article 5 provides direct support for the proposition that subsidiarity contains a proportionality component: "[T] he Community shall take action ... only if and insofar as the objectives of the proposed action cannot be sufficiently achieved by the Member States"451_ "insofar as" here implying "only to the extent that." 452

Conversely, as George Bermann notes, proportionality also contains a subsidiarity component. Proportionality requires that the Community opt for the least burdensome of the various alternatives available for achieving the intended legislative objective. Although a Community measure may be reasonably related to its stated purpose and advantageous from a cost-benefit standpoint-both elements of proportionality-the measure "may nevertheless not have been necessary, in the sense that action taken at the Member State level, or perhaps non-regulation altogether, would have been quite effective in achieving the Community's goals." 453

Hence, the British position in the Working Time Directive case-that "a measure will be proportionate only if it is consistent with the principle of subsidiarity" 454 _is justified both by a reasonable understanding of the proportionality principle and a fair reading of the subsidiarity language in the Treaty itself. In its challenge to the Working Time Directive, the United Kingdom in effect argued for an interpretive presumption against a broad reading of the Community's autonomous legislative authority not unlike the one advanced earlier in this Article. ${ }^{455}$ In the case of thenArticle 118a, the United Kingdom asserted that the Community's authority to adopt directives regarding the "working environment," as well as "the health and safety of workers," should be limited to regulating the

449. Subsidiarity Protocol, supra note 432, section 3 (emphasis added).

450. Bermann, Taking Subsidiarity Seriously, supra note 48 , at 336 .

451. EC Treaty art 5 (emphasis added).

452. Other language versions of the Treaty are to the same effect. See, e.g., the German version of Article 5, which provides: "wird die Gemeinschaft nach dem Subsidiaritātsprinzip nur tätig, sofern und soweit die Ziele der in Betracht gezogenen Maßnahmen auf Ebene der Mitgliedstaaten nicht ausreichend erreicht werden kōnnen und daher wegen ihres Umfangs oder ihrer Wirkungen besser auf Gemeinschaftsebene erreicht werden können." The German "soweit" is the exact translation of English "in so far," with "so" meaning "so" and "weit" meaning "far." Official language versions of the Treaties generally have a very high linguistic equivalence, for the reason that the Treaty must be equally authentic in all eleven official languages.

453. Bermann, Taking Subsidiarity Seriously, supra note 48 , at 388 .

454. Working Time Directive, 1996 E.C.R. I-5755, I-5810, para. 54, [1996] 3 C.M.L.R. 671,718 , para. 54.

455. See supra notes 336-339 and accompanying text. 
"physical conditions and risks at the workplace." 456 It should not be read as extending to other non-physical factors like working time broadly conceived unless there existed "a genuine and objective link to the 'health and safety' of workers." 457 Moreover, the United Kingdom asserted, then-Article 118a's reference to "minimum requirements" should be read literally, empowering the Community "to adopt harmonisation measures only at a level acceptable to all Member States and constituting a minimum benchmark. ${ }^{n 58}$

In support of this position, the government of the United Kingdom might have looked to an American administrative law analogue-the decision of the United States Supreme Court in the so-called Benzene case. ${ }^{459}$ The plurality opinion in Benzene provides a useful guide for proceeding with terms like "safety" and "health" in a regulatory statute, requiring that the relevant decisionmakers find that a condition is "unsafe" or "unhealthy" before they can legislate. ${ }^{460}$ The plurality opinion of the Supreme Court stressed that allowing the administrative sphere to make rules without such a finding would amount to "such a 'sweeping delegation of legislative power' that it might be unconstitutional" under the American nondelegation doctrine. ${ }^{461}$ Similarly restricting the scope of the Community's normative autonomy relative to the Member States is especially necessary with regard to provisions like the old Article 118a, of which the key terms ("health" and "safety") were at best ambiguous, largely due to the fact that they resulted from a legislative compromise

456. Working Time Directive, 1996 E.C.R. at I-5799, para. 13, [1996] 3 C.M.L.R. at 710, para. 13.

457. Id. at I-5799-5800, paras. 13-15, [1996] 3 C.M.L.R at 710-11, paras. 13-15.

458. Id. at I-5800, para. 16, [1996] 3 C.M.L.R at 711, para. 16.

459. See Industrial Union Dep't, AFL-CIO v. American Petroleum Inst., 448 U.S. 607 (1980) [hereinafter Benzene]. This action involved the power of the U.S. Secretary of Labor to promulgate "occupational safety and health standards" under the Occupational Safety and Health Act of 1970, Pub. L. No. 95-596, 84 Stat. 1590, codified at 29 U.S.C. $\$ 651$ et seq. (1994). Section 3(8) of the Act defined such standards as those "reasonably necessary or appropriate to provide safe or healthful employment and places of einployment." 29 U.S.C. $\$ 652(8)$. Section 6 (b) (5), on the other hand, obligated the Secretary to issue standards "to the extent feasible." 29 U.S.C. $\$ 655(b)(5)$. The reasonableness language of the definitional provision implied a cost-benefit analysis, and the feasibility language of the substantive provision could imply, but did not necessarily, the most protective standard regardless of cost or tecbnology. Although the grant of rulemaking authority under section $6(b)(5)$ was seemingly open-ended-not unlike the ECJ's interpretation of Article 118a-the plurality opinion of the Supreme Court held that the Act required the Secretary "to inake a threshold finding that a place of employment is unsafe-in the sense that significant risks are present and can be eliminated or lessened by a change in practices" - before promulgating a new standard. Benzene, 448 U.S. at 642 (emphasis added).

460. See Benzene, 448 U.S. at 642.

461. Id. at 646 (quoting A.L.A. Schechter Poultry Corp. v. United States, 295 U.S. 495, 539 (1935); Panama Refining Co. v. Ryan, 293 U.S. 388 (1935)). The plurality's holding may be read as a response to Justice Rehnquist's urging that the statute be struck down on nondelegation grounds. See 448 U.S. at 685-86 (Rehnquist, J., concurring in the judgment). 
among the Member States themselves. ${ }^{462}$ Using subsidiarity as an interpretive principle permits the delegation of legislative authority to the supranational level, but also reasonably restricts the scope of that authority in the interest of more democratically legitimate regulation at the Member State level.

Consistent with the constitutionalist perspective, subsidiarity has too often been viewed simply as a principle of an emergent European "federalism," 463 thus conferring a degree of sovereign legitimacy on the Community that it does not independently possess, apart from delegations by the Member States. Properly understood, the subsidiarity principle in the European Community must, at a minimum, serve the same interpretive function as the nondelegation doctrine in the United States, favoring Treaty interpretations that minimize the Community's normative autonomy. Viewed in a nondelegation sense, subsidiarity becomes a means of ensuring "that important choices of social policy are made by ... the branch of our Government most responsive to the popular will." 464 In the Community legal system, the Member States severally are the "branch" most responsive to the popular will. The Court's expansive interpretation of provisions like the old Article I18a should be strongly disfavored unless there is clear evidence of a "legislative" intent on the part of the Member States to confer such authority on the Community as their agent. ${ }^{465}$ Indeed, the Court's decision in the Working Time Directive case, as well as the published opinion of the Advocate-General in that case, leave serious questions as to whether any such evidence exists. ${ }^{466}$

462. See Working Time Directive, 1996 E.C.R. at I-5765, para. 34, [1996] 3 C.M.L.R. at 683, para. 34 (Opinion of Advocate-General Léger) (noting that interpreting Article I18a is a delicate matter because of the different views that collaborated to create this compromise version).

463. See, e.g., Bermann, Taking Subsidiarity Seriously, supra note 48.

464. Benzene, 448 U.S. at 685 (Rehnquist, J., concurring in the judgment).

465. Cf. Majone, "Democratic Deficit," supra note 55, at 28 (stating that a "precise[ ] and narrow [ ]" definition of the assigned regulatory tasks is a necessary precondition to the delegation of normative power to Community institutions).

466. Neither the Court nor Advocate-General Léger could produce persuasive evidence of a legislative intent supporting a broad reading of Article I18a, which forced them to turn instead to highly debatable textual interpretations of the Community's authority. The Court stressed the words "especially in the working environment" in Article 118a, which it saw as "militat [ing] in favour of a broad interpretation of the powers which Article 1I8a confers upon the Council for the protection of the health and safety of workers." Working Time Directive, 1996 E.C.R. at I-5800, para. 15. Lacking solid evidence of the Member States' intent, the Court then asserted that a broad reading of the words "safety" and "health" "derives support in particular from the preamble to the Constitution of the World Health Organisation to which all the Member States belong. Health is there defined as a state of complete physical, mental and social well-being that does not consist only in the absence of illness or infirmity." Id.

Advocate-General Léger's argument was somewhat inore elaborate but also devoid of sohid evidence of an intent that Article 1I8a should be interpreted broadly. See id. at I5767-70, paras. 39-50 (Opinion of Advocate-General Léger). Aside from the WHO evidence on the nieaning of "health" also cited by the Court, which is of questionable 


\section{Choice of Legal Basis and Subsidiarity as a Nondelegation Doctrine}

The scope of any one Treaty provision necessarily bears on the more fundamental question of the choice of legal basis and, by extension, of the required voting procedure in the Council-unanimity versus qualified-majority. On its face, the Working Time Directive case involved a dispute over whether a qualified-majority basis (Article 118a) or a unanimity basis (either Article 100 or Article $235^{467}$ ) was appropriate in the circumstances. ${ }^{468}$ Here, too, subsidiarity should be used as an interpretive principle presumptively favoring the Member States. That is, where there is ambiguity as to what the appropriate legal basis should be for a particular piece of legislation like the Working Time Directive, the Court should opt for the basis which mandates unanimity in the Council as a means of protecting the prerogatives of the individual Member States. ${ }^{469}$

The Working Time Directive case, however, also points to the tensions that will inevitably flow from the Community's increasingly prevalent variable geometry. At the heart of variable geometry in Community law is the right of certain Member States not to participate in particular categories of legislation, which this Article views as a means of asserting national control over legislative domains otherwise claimed by the Community. 470 These rights may give rise to potentially difficult problems of line-drawing between those general legal bases applicable to all Member States-like the old Article 118a-and those from which a particular Member State has secured a right not to participate. 471

The conflict over the Working Time Directive suggests how subsidiarity can also serve a useful interpretive function in this context as well. Underlying the case was arguably the tension between the Commu-

relevance at best, Advocate-General Léger cited a Danish statute to support his reading of the term "working environment." Id. at I-5767, para. 42 (citing The Danish Worhing Environment Act, Law 681 of 23 December 1975, which entered into force on July 1, 1977 (printed by the Danish Labour Inspection Service, Copenhagen, 1981)). The AdvocateGeneral argued that this statute was relevant because the original proposal for the Worhing Time Directive had come from Denmark.

467. Now EC Treaty arts. 94 and 308.

468. We need not dwell on the United Kingdom's legal basis argument, as it was grounded in the already extensively descrihed narrow reading of Article 118a, which thus left only Article 100 or 235 (now art. 94 or 308) as the possible legal bases. Article 100 provided general authority to adopt harmonization directives for the establishment of the common market. Article 100a (added to the EC Treaty by the SEA in 1986) changed the voting mechanisin for directives in completion of the internal inarket to qualified majority, but by its terms (see Article 100a(2)), it did not apply to legislation "relating to the rights and interests of employed persons." Article 235 was the Community's "necessary and proper" clause, and also required unanimity. See supra notes 154-156 and accompanying text for a discussion of Article 235.

469. See, e.g., my critique of the ECJ's decision in Titanium Dioxide Waste, 1991 E.C.R. I-2867, I-2900, [1993] 3 C.M.L.R. 359, supra notes 378-390 and accompanying text.

470. See supra notes $380-387$ and accompanying text.

471. See the discussion of variable geometry and the hikelihood of intensified disputes over the relative competences of the Community and the Member States, supra Part III.D. 
nity's general legislative authority under the old Article 118a to regulate "health and safety of workers," and its more specific authority-from which the United Kingdom had expressly opted out-under the so-called Protocol and Agreement on Social Policy attached to the Treaty on European Union in 1992. ${ }^{472}$ Under the terms of the Protocol, any legislation adopted under the Protocol and Agreement would not be binding on the United Kingdom. ${ }^{473}$ The Protocol and Agreement authorized the remaining Member States, excluding the United Kingdom, to adopt directives for, inter alia, "the promotion of employment, improved living and working conditions, [and] proper social protection." ${ }^{474}$ Confusingly, Article 2 of the Agreement nearly tracks the language of the old Article 118a, speaking of social legislation for "the improvement in particular of the working environment to protect workers' health and safety." 475 There was little or no guidance as to what distinguished a "health and safety" measure based on the old Article 118a from one based on Article 2 of the Agreement, save perhaps that the latter were also adopted for "the promotion of employment, improved living and working conditions, [and] proper social protection." 476

In its challenge to the Working Time Directive, the United Kingdom asserted that the Council had misused the Community's authority under then-Article 118a to pursue other social policy goals, notably job creation and reduced unemployment. ${ }^{477}$ The Court responded to this argument by again relying on conclusory assertions in the directive's recitals, ${ }^{478}$ in much the same way as it responded to Germany's subsidiarity claim in the Deposit-Guarantee Schemes case. ${ }^{479}$ The Court did not dispute that the Working Time Directive "may affect employment," 480 but argued that it "is so broad in its scope and coverage as to be capable of classification as a social policy measure, for the adoption of which other legal bases ex-

472. 1992 O.J. (C 224) 126-29. For an overview of the evolution of Community social policy, with particular reference to the United Kingdom's refusal to take part in the expansion of Community competences in this field in the late 1980s and early 1990s, see David O'Keeffe, The Uneasy Progress of European Social Policy, 2 Colum. J. Eur. L. 241 (1996); see also Ferdinand von Prondzynski \& Ada Kewley, Social Law in the European Union: The Search for a Philosoplyy, 2 Colum. J. Eur. L. 265 (1996) (discussing social policy issues in light of the U.K opt-out from the Social Policy Protocol of the Treaty on European Union).

473. Protocol on Social Policy, sec. 2, paras. 1 and 3, 1992 O.J. (C 224) 126.

474. Agreement on Social Policy art. 1, 1992 O.J. (C 224) 127.

475. Id., art. 2.

476. Id., art. 1.

477. See Working Time Directive, 1996 E.C.R. I-5755, I-5763, para. 26 (Opinion of Advocate-General Léger) (citing sections 3.12 and 3.13 of the United Kingdom's application to the Court). One night also speculate that one ain of the directive was to impose greater labor costs on firms operating in the United Kingdom, reducing that country's competitive advantage over other Member States with more costly systems of legally mandated workers' benefits, such as France and Germany.

478. See id. at I-5803-04, para. 29.

479. See supra notes $427-431$ and accompanying text.

480. Working Time Directive, 1996 E.C.R. at I-5804, para. 30. 
ist."481 Although the Court further conceded that "the directive constitutes a practical contribution towards creating the social dimension of the internal market," 482 the Court asserted that "it does not follow from the fact that the directive falls within the scope of Community social policy that it cannot properly be based on Article 118a, so long as it contributes to encouraging improvements as regards the health and safety of workers." 483

Here, precisely, is the weakest element of the Court's reasoning. As the United Kingdom persuasively demonstrated-and as the Court effectively conceded-there was no scientific evidence that the directive's provisions would actually contribute to workers' health and safety. ${ }^{484}$ Given this absence, as well as the ambiguity with regard to the appropriate legal basis for the legislation, the Court should have, in the interest of subsidiarity, favored an interpretation of the Treaty that best preserved the rights of the opted-out Member State. 485

The impact on the remaining Member States would have been minimal, unless, of course, the purpose of the measure was to make social costs more uniform across the Community, removing the competitive advantage of low-cost Member States. This is a perfectly legitimate objective, but if it were the true purpose, the old Article 118a would clearly have been an inappropriate legal basis. Had the Court rejected Article $118 \mathrm{a}$ as the appropriate legal basis, it would have merely forced the remaining Member States to proceed under either a unanimity basis or under the authority granted in the Protocol and Agreement on Social Policy attached to the TEU. In the latter circumstance, both the United Kingdom and the remaining Member States would have benefited from precisely the flexibility that advocates of variable geometry have hoped to introduce into Community law. ${ }^{486}$

481. Id. at 1-5803, para. 26.

482. Id., para. 27 (citing the sixth recital in the preamble of the Working Time Directive).

483. Id.

484. The Court implied as much when it stated that the authority to adopt a larmonization directive "cannot be limited exclusively to circumstances where the justification for such action is scientifically demonstrated." Id. at I-5806, para. 39 (citation ounitted).

485. At a minimum, one might have expected the Court, in its interpretation of the scope of the old Article 118a, at least to take cognizance of the potential overlap with Article 2 of the Agreement. Even if subsequently negotiated, the Protocol and Agreement would seem to indicate an understanding by the Member States that the scope of the old Article 118a was insufficiently broad to encompass health and safety rules adopted primarily for social policy purposes-in contradiction to what the majority of Member States were claiming for the old Article 118a at the time of the adoption of the Working Time Directive. Otherwise, the more expansive langnage of Article 2 of the Agreementagain, from which the United Kingdoin had expressly opted out-would have been unnecessary. Certainly, this constitutes more concrete evidence of Member State intent than the evidence cited by the Court and the Advocate-General. See supra note 466 .

486. See supra notes 180-194 and accompanying text. 
Therefore, while the benefit in terms of Community legislation was arguably small, the cost of sanctioning this use of the old Article 118a in this way was, in terms of democratic legitimacy, quite high. The Court's disposition of the Working Time Directive case was not simply contrary to the spirit of subsidiarity; rather, the decision actually circumvented the democratic process at the national level. It was ultimately the right of the British people to judge the decision of its national government to opt out of Community social legislation - which they in part did by giving Labour a majority in the 1997 general election. ${ }^{487}$ It was not for the Commission and the remaining Member States, exploiting a debatable understanding of the extent of Community competences under then-Article 118a, to impose their will on the British government and people. By sanctioning this claim of open-ended normative power at the supranational level, the Court undermined still further the democratic legitimacy of Community institutions.

\section{The Issue of KompETENZ-Kompetenz: TOWARd a EuROPEAN Conflicts TRIBUNAL}

Had the British electorate kept the Conservatives in office after 1997, the Government would have had little or no recourse, either politically or legally, to challenge the Court's Working Time Directive decision. Although a negotiated political solution with the remaining Member States was not, formally speaking, out of the question, it was almost certainly a practical impossibility. ${ }^{488}$ Moreover, the possibility of a further legal challenge under Community law was non-existent. The ECJ had long held that it,

487. Indeed, the Labour Party's election manifesto committed a Labour government to adopt the Social Protocol and Agreement (the "Social Chapter") as part of a more general plan to offer a "fresh start in Europe." Labour Manifesto, Times (London), Apr. 4, I997, at IV. The Conservatives tried to make this commitment a major campaign issue but still lost. Ian Lang, President of the Board of Trade under the Conservative government of John Major, asserted that the Labour Manifesto was "the biggest IOU to the unions in British electoral history. Promise after promise conforms exactly to the unions' agenda: statutory umion recognition, a national minimum wage and the European Social Chapter." Labour's Manifesto is the "Biggest I.O.U. in British Electoral History," Universal News Servs., Apr. 3, 1997, available in LEXIS, News Library, Non-U.S. File. Furthermore, at a press conference at Conservative Party headquarters on the eve of the General Election, John Major asked the voters specifically not to vote for Labour "[b]ecause if Labour follow policies like those in Europe and sign up to the Social Chapter and minimum wage, the extra costs on business mean we would get Europe's unemployment too." You'll be worse off under Labour, M2 Presswire, Apr. 30, 1997, available in NEXIS, News Library, Non-U.S. File. The Labour government of Tony Blair confirmed soon after the election that the United Kingdom would end its opt-out at the Intergovernmental Conference of 1997, and the provisions of the Agreement have since been incorporated into the Treaty of Amsterdam, inserting new Articles 117-120 into the EC Treaty (arts. 136-143).

488. Repeal of the Directive itself would have required, under the old Article 118a(2), a qualified majority in the Council and Parhamentary "cooperation" under Article 189c (now Article 252), whereas negotiating a Treaty revision of the scope of Article 118a would have required unamimous consent of the Member States. Both were unhikely prospects given that the British Conservatives were isolated in their opposition to the measure. 
and it alone, had exclusive competence to rule on the validity of a Community act. 489 This authority necessarily includes the exclusive competence to rule on the extent of Community competences, or, as it is called in German, Kompetenz-Kompetenz. The Court had thus established itself as the supreme legal arbiter of the scope of the Community's authority relative to the Member States, from which there was no legal appeal. ${ }^{490}$

The Working Time Directive decision is evidence of how democratically problematic the ECJ's claim of Kompetenz-Kompetenz has become since the advent of qualified-majority voting in the Council in 1986. By expanding the relative autonomy of Community institutions from Member State control, qualified-majority voting creates a classic principal-agent problem, albeit one with an important supranational twist, owing directly to the lack of a democratically-legitimate hierarchical superior within the Community legal system. ${ }^{491}$ A Member State's ministerial representatives in the Council could now find themselves in disagreement with their "coprincipals," the ministers representing the other Member States, who might agree with the Commission's legislative proposal and adopt it in the form of a directive. It is not simply a situation analogous to a member of a national legislature finding him or herself in the minority on a piece of legislation. No individual legislator can make a claim to sovereignty under international law as can a nation-state. ${ }^{492}$ Nor can individual legislators representing particular subnational constituencies claim the same measure of democratic legitimacy that the Member State executives derive from representing a national community in the Council.

The only recourse for the dissenting Member State or States is to challenge the action before the ECJ. Yet, because the ECJ has consistently favored a broad interpretation of the Community's legislative competences, any one Member State or group of Member States that found itself on the short end of a qualified-majority vote would take little comfort in the fact that legal action before the Court was available. Because of its teleological "preference for Europe," the Court has demonstrated itself to be an unreliable defender of the interests of particular Member States against the Community as a whole. This is especially true on juris-

489. See, e.g., Case 314/85, Firma Foto-Frost v. Hauptzollamt Lübeck-Ost, 1987 E.C.R. 4199; Case 66/80, SpA Int'l Chem. Corp. v. Amministrazione delle Finanze dello Stato, 1981 E.C.R. 1191.

490. In this regard, the ECJ benefits from what Joseph Weiler has called "that deepseated legitimacy that derives from the mythic neutrality and religious-like authority with which we invest our supreme courts." Weiler, Transformation, supra note 31 , at 2428 . In a press release following the Court's announced decision, the then-President of the Board of Trade in Britain, Ian Lang, said: "The European Court of Justice has now given its judgment, and we will obey the law." United Kingdom Government Press Release, P/96/ 915, 6 Dec. 1996, available in LEXIS, INTLAW Library, EC NEWS File.

491. See supra notes 165-168 and accompanying text.

492. This is true culturally no matter how tenuous that claim is increasimgly becoming as an empirical matter. 
dictional questions: The Court has never struck down a piece of Community legislation "for pure and simple lack of competence." 493

Individual Member States could tolerate this state of affairs prior to 1986, when unanimous voting gave each a veto over the Community's legislative output. With the advent of qualified-majority voting, however, "the seeds-indeed the buds-of crisis became visible." ${ }^{\text {"94 }}$ In 1990, Joseph Weiler, writing with Jean Paul Jacqué, foresaw "a ticking constitutional time bomb which one day might threaten the evolution and stability of the Community." 495 Professors Jacqué and Weiler continued:

Sooner or later, "supreme" courts in the Member States would realise that the "socio-legal contract" announced by the Court in its major constitutionalising decisions, namely that "the Community constitutes a new legal order ... for the benefit of which the states have limited their sovereign rights, albeit within limited fields" (emphasis added) has been shattered, that although they (the "supreme" courts) have accepted the principles of the new legal order-supremacy and direct effect-the fields [do] not seem any more to be limited, and that, in the absence of Community legislative or legal checks it will fall on them to draw the jurisdictional lines of the Community and its Member States. ${ }^{496}$

This prediction proved prescient. In 1994, in what is known as the Maastricht Decision, the German Federal Constitutional Court explicitly asserted its independent authority, as a matter of German constitutional law, to rule on the outer scope of Community competences, effectively rejecting the ECJ's claim of exclusive Kompetenz-Kompetenz. 497 On its face, the German Maastricht Decision appears to be "an egregious violation of the Treaty" 498 and "incompatible with the needs of contemporary Europe." 499 However, in perhaps the most penetrating examination of the legal-theoretical underpinnings of the decision, Neil MacCormick has shown that these sorts of "criticisms are altogether too hasty." 500 Professor MacCormick argues that the relationship between the highest tribunals in the Member States and the ECJ must be understood as "pluralistic

493. Weiler \& Trachtman, supra note 23, at 388.

494. Id.; see also J.H.H. Weiler, The Reformation of European Constitutionalism, 35 J. Common Mkt. Stud. 97, 124 (1997) [hereinafter Weiler, Reformation]; J.H.H. Weiler \& Ulrich R. Haltern, The Autonomy of the Community Legal Order-Through the Looking Glass, 37 Harv. Int'I L.J. 411, 445 (1996); Weiler et al., supra note 128, at 36; Jean Paul Jacqué \& Joseph H.H. Weiler, On the Road to European Union-A New Judicial Architecture: An Agenda for the Intergovernmental Conference, 27 Common Mkt. L. Rev. 185, 201 (1990).

495. Jacqué \& Weiler, supra note 494 , at 200.

496. Id. at 200-01 (emphasis and parentheticals in original).

497. See Brunner v. European Union Treaty, 1 C.M.L.R. 57, 89 (BVergG 1994)

(Germ.) [heremafter Maastricht Decision].

498. Weiler \& Haltern, supra note 494 , at 445.

499. MacCormick, Sovereignty Now, supra note 51, at 265.

500. $1 \mathrm{~d}$. 
rather than monistic, and interactive rather than hierarchical." ${ }^{" 01} \mathrm{He}$ argues that "it must be for the highest constitutional tribunal of each Member State to interpret its constitutional and other norms, and hence to interpret the interaction of the validity of EC law with higher level norms of validity in the given state system." 502

Following Professor MacCormick's lead, Joseph Weiler has used the metaphor of a "conversation" between "two constitutionalisms" to describe the interaction between national courts and the ECJ.503 Rather than there being a hierarchical judicial structure with the ECJ at the top, Professor Weiler sees "a constitutional interpretive community" composed of the "supreme" courts in the various Member States and the ECJ. ${ }^{504}$ As a means of institutionalizing that conversation, Professor Weiler and his many collaborators have suggested the creation of a "Constitutional Council" for the Community, modeled in part on its French namesake. ${ }^{505}$ The President of the ECJ would serve as the presiding judge over the new tribunal, and the remaining judges would be drawn from sitting members of the constitutional courts or their equivalent in the Member States. The jurisdiction of the Constitutional Council would be limited to questions of competences, including subsidiarity. By composing this Constitutional Council of judges from national tribunals, Professor Weiler would hope to "underscore that the question of competences is fundamentally one of national constitutional norms," some of the cultural tensions associated with supranational delegation that have been described earlier. 507

Professor Weiler's proposal moves in the correct direction but, from the administrative perspective advanced here, is flawed both practically and theoretically. As a practical matter, the proposal excessively restricts both the timing of review and the standing of the parties entitled to bring a claim before the new tribunal. According to Professor Weiler, only Community institutions (including the European Parliament acting on a majority of its members) or the Member States (presumably their executives) should have the right to submit an action, and only in the interim between the law's adoption and its coming into force. ${ }^{508}$ If the purpose of the proposal is to institutionalize a "conversation" over the relative boundaries of Community and Member State competences, this sort of "abstract norm control" in the French tradition is an extremely narrow way of facilitating it. National courts and especially individual litigants

501. Id.

502. Id. at 264.

503. Weiler, Reformation, supra note 494, at 125.

504. Id. at 127.

505. Weiler \& Trachtman, supra note 23 , at 391-92; see Weiler, Reformation, supra note 494 , at 127; Weiler \& Haltern, supra note $494,447-48$; Weiler et al., supra note 128 , at 38; see also Jacqué \& Weiler, supra note 494, at 204.

506. Weiler, Reformation, supra note 494, at 127.

507. See supra notes $83-90$ and accompanying text.

508. Compare Fr. Const. art. 61. 
should be allowed to participate in the conversation as well, by raising questions of competences in the context of actual litigation, assuming that the litigant has suffered some injury-in-fact reasonably traceable to the Community legislation at issue. ${ }^{509}$ Expanding standing in this way will bring decisionmaking closer to the individual while also perhaps improving the quality of review, by giving the new tribunal a concrete set of facts upon which to rule. More importantly, it will put the national courts in a position to use precisely the same sort of "courteously didactic method" with the ECJ on questions of competences that the EGJ has long used with national courts in the pursuit of European integration. ${ }^{510}$

On a theoretical level, Professor Weiler's proposal also exhibits insufficient sensitivity to the legitimate prerogatives of the Member States as loci of democratic legitimacy within the Community. Professor Weiler acknowledges that "[ $\mathrm{t}]$ here has been no constitutional convention in Europe"; nevertheless, he wants to establish an institution that will avoid "compromising the constitutional integrity of the Community as did the German Maastrcht decision."511 If one believes, as I do, that the Community is better understood as administrative in character, and that the greatest threat to its integrity is the lack of democratically-legitimate political control over its norm production, the Constitutional Council as proposed would do little to address this central problem.

There are attractive elements to the proposal: staffing of the new tribunal with sitting national judges, and shifting the telos of the new body to scrutinizing with greater care the boundary between national and Community competence, as the EGJ has shown little willingness to do. Unfortunately, other aspects of the proposal risk exacerbating the problem of legitimate political control by, for example, precluding any Member State from exercising a veto within the new body and by underscoring that all disputes are "subject to a [supranational] solution by a [supranational] institution." 512 Perhaps its most significant drawback is that the new tribunal constitutes an exclusively legal solution to a problem that is both legal and political. "[N]ot all legal problems can be solved legally," Neil MacCormick warns, and "[r] esolving such problems, or more wisely still, avoiding their occurrence in the first place, is a matter for circumspection and for political as much as legal judgment." 513 Thus, the challenge facing Europe is to develop an institution that attempts to resolve conflicts between Community and Member State competences as far as

509. The application of some form of injury-in-fact doctrine will ensure that the individual litigant is seeking to redress something more than simply a generalized grievance against the adoption of Community legislation.

510. Mancini, supra note 102, at 606.

511. Weiler, Reformation, supra note 494, at 126-27. The character of the Community as a constitutional entity is apparently emerging, in Professor Weiler's view, from "a common-law type" process, "one which draws on and integrates the national constitutional orders . ...." Id.

512. 1d. at 127.

513. MacCormick, Sovereignty Now, supra note 51, at 265. 
possible legally, but nevertheless builds in political rights that fully account for the greater democratic legitimacy of the Member States.

Principles of administrative law again may prove useful here. From an administrative perspective, the ECJ's claim of unchecked KompetenzKompetenz should be rejected because it amounts to allowing the adjudicative branch of an administrative agency to act as the final and exclusive judge of the scope of the agency's own jurisdiction. In defense of this state of affairs, one might counter that the Community simply follows the French administrative tradition, with a separate system of justice organically attached to the administrative sphere but also historically independent from it, 514 a claim that the ECJ can certainly substantiate vis-à-vis the Community's "political" branches. Even in the French tradition, however, the administrative courts are not the ultimate judge of the scope of administrative competence, at least relative to the judicial courts. In cases of conflict between the two orders of jurisdiction, a Tribunal des Conflits is convened, comprised of judges from both the supreme administrative and judicial courts (the Conseil d'État and the Cour de Cassation), to rule on the conflict. 515

The time has come, as Joseph Weiler has correctly recognized, to establish a similarly distinct body at the European level-what I call a "European Conflicts Tribunal" - to rule on the question of the relative competences of the Community and the Member States, not merely of their courts but more importantly of their respective "legislatures" as well. My proposed tribunal would be comprised, like Professor Weiler's "Constitutional Council," of sitting judges from national supreme courts or their equivalent, and be presided over by the president of the ECJ. Decisionmaking in the new tribunal, however, would not be limited to "abstract norm control" upon reference by a Member State or Community institution; 516 rather, I would also allow national courts and individual litigants to interpose conflicts of jurisdiction as well, as long as individual

514. See generally Jacques Chevallier, L'Elaboration historique du principe de séparation de la juridiction administrative et de l'administration active (1970).

515. See generally L. Neville Brown \& John S. Bell, French Administrative Law 152-56 (5th ed. 1998). Conflicts between judicial and administrative jurisdiction have a deep significance in the political and legal history of France, extending back to the Old Regime. See, e.g., Alexis de Tocqueville, The Old Regime and the French Revolution, Part Two, Chapter Four (Stuart Gilbert trans., 1955) ("How administrative justice and the immunity of public servants were institutions of the old regime."). Much of the tension owed to the fact that, until the definitive establishment of the Third Republic in the 1870s, the Conseil d'Etat possessed ultimate authority to rule on the scope of administrative jurisdiction relative to the ordinary judicial courts-in effect, Kompetenz-Kompetenz. A cornerstone of the new Republican legal order established in the 1870s was the transfer of KompetenzKompetenz to a distinct body, the Tribunal des conflits. See c. Adm. 539 (20th ed. Dalloz 1989) Law of May 24, 1872, art. 25.

516. Community institutions and the Member States would have standing to challenge the Community act, but only after first bringing an Article 230 (ex art. 173) action in the European Court of Justice. Member States could also interpose a conflict in an Article 226 (ex art. 169) enforcement proceeding brought by the Commission. 
standing requirements are satisfied and the available national and EC legal remedies are exhausted first. This exhaustion requirement would have two parts: first, that the national court make a preliminary reference to the ECJ under Article 234 (ex Article 177) on the question of the scope of Community law; and second, that all appeals then be exhausted at the national level, including full appeal to the highest court in the relevant judicial hierarchy on the question of the conflict between Member State and Community competence. If the supreme appellate court at the Member State level finds that the Community has overstepped its authority, the matter should then be referred to the European Conflicts Tribunal.

Should a decision of the European Conflicts Tribunal be the end of the matter? The new tribunal would still constitute a supranational body, in that no single Member State would have a veto over its decisionmaking. Following Neil MacCormick's admonition that "not all legal problems can be solved legally," ${ }^{217}$ the Community should explore whether to give the Member States a further "political" right of appeal from a decision of the Conflicts Tribunal. If the dissenting Member State or States are dissatisfied with the ruling of the Conflicts Tribunal, one option could be to refer the matter to the European Council for consideration at its regular semi-annual summit. This body, composed of the heads of state or government and the foreign ministers of each Member State, along with the President of the European Commission and the Commissioner for External Affairs, is charged with defining the "general political guidelines" of the entire European Union. ${ }^{518}$ It therefore constitutes the most appropriate political forum within which to debate the question of conflict over the relative competences of the Community and the Member States. If the concerned Member State cannot negotiate a satisfactory political solution within the European Council, the Member State should then be allowed to opt out of the legislation.

This Conflicts Tribunal procedure attempts to strike a balance between the need for uniformity and stability in Community law and the more democratically-legitimate prerogatives of the Member States. A stabilizing element of the proposed conflicts procedure is that it will first require a dissenting Member State to state in legal terms its objection to Community competence, thus favoring the development of legal principles-including subsidiarity-to define the relative boundary between national and Community authority. This essentially judicial process, in turn, should benefit the quality of political and technical deliberation within Community institutions as well, by forcing the relevant players to take cognizance of colorable jurisdictional objections at an earlier

517. MacCormick, Sovereignty Now, supra note 51, at 265 (suggesting giving due regard to political considerations in interpreting the relative competences of the ECJ and the national courts).

518. TEU art. 4 (ex art. D). 
stage.519 It largely allows the regular process of Community legislation and judicial review to proceed in the first instance, and further makes a Member State's ultimate right to opt out subject to a number of significant procedural conditions precedent. In this sense, it is not unlike the closer cooperation procedures of the new Treaty of Amsterdam and is simply another manifestation of the emerging variable geometry in Community law. 520

The most important dimensions of the proposal, however, are the political rights of appeal and opt-out, in that those rights attempt to address the "normative yearning" for legitimate democratic control over administrative decisionmaking that I believe lies at the center of the democratic deficit, both nationally and supranationally.521 The elected governments of the Member States, as the more legitimate decision makers, should have ultimate political responsibility-subject to significant legal conditions precedent-to determine the relative scope of national and supranational competences insofar as they affect the content of regulatory norms applicable within national borders. Should the government of a Member State decide to opt out after pursuing the conflicts process to its judicial and political conclusion, it will then be for the national electorate, in the exercise of its democratic rights, to judge whether the government's decision was in the country's best interests.

Undoubtedly, the existence of an opt-out right raises legitimate concerns regarding the incentives given to potentially uncooperative $\mathrm{Mem}-$ ber States. Governments of Member States facing the greatest increased costs from the adoption of a new piece of Community legislation-the hypothetical "up-stream" polluter, for example-will also have the greater incentive to opt out, making it even more difficult to reach consensus on public-regarding legislation at the Community level. Perhaps more dangerously, a particular Member State government may choose to opt out solely to cement political deals with powerful constituencies at home, regardless of a potentially positive impact on the overall domestic economy.

In my view, however, these objections are not decisive. The choice to opt out would carry significant political costs, and the prospect of incurring these costs may in fact tend toward public-regarding legislation at the Community level rather than against it, while also augmenting the legislation's democratic legitimacy. A decision by a Member State govern-

519. I hypothesize an effect similar to that which Alec Stone has described with regard to the French Constitutional Council. See Alec Stone, The Birth of Judicial Politics in France: The Constitutional Council in Comparative Perspective 122-29 (1992) (arguing that the prospect of constitutional review by the Council has "juridicized" the policymaking process in France, more specifically through the process of autolimitation ("the government's exercise of legislative self-restraint from anticipation of a referral to, and an eventual negative decision of, the Constitutional Council") and corrective revision ("where lawmakers are forced to rewrite legislation after a negative decision")).

520. See supra notes 180-194 and accompanying text.

521. See supra notes $311-316$ and accompanying text. 
ment to opt out, after a very public invocation of the Conflicts Tribunal and reference to the European Council, should be sufficiently controversial as to garner the attention of the domestic press, both specialized and general. The ensuing public debate should in fact reduce the institutional "slack" that might allow a Member State government to conceal its decision from the broader public.522 In turn, the very publicness of a Member State government's decision to opt out will counter the otherwise weak incentives for citizens to inform themselves about the details of government policy. ${ }^{523}$ All in all, the incentives structure created by the conflicts process proposed here-including the opt-out right-should force Member State governments to pay greater attention to the electoral consequences of their positions with regard to the particular European legislation at issue.

\section{CONCLUSION}

Is the European Community so unique as a supranational body that it is difficult to draw general lessons from its experience? Certainly the Community is distinguished from other international organizations in its range of delegated normative powers, both legislative and adjudicative, as well as its relative independence from unilateral Member State control. No other international organization can claim similar authority, or at least not to the same extent. I would argue, however, that this indisputably broad range of autonomous normative powers does not distinguish the Community in its legal character from other less ambitious experiments with supranational delegation, such as the dispute settlement panels of the WTO. All such organizations share a similar telos-"to overcome the significant coordination or collective-action problems that [the] membership otherwise faces."524 They use similar means in pursuit of that telos-delegation of normative power to a non-national body of experts-thus displacing the elaboration and/or control of a range of regulatory questions into the realm of international technocratic networks. They are, in other words, essentially of an administrative character.

One might argue that the European case remains unique in the manner in which its delegated normative powers have been rationalized in constitutionalist terms, as leading toward "an ever closer union among the peoples of Europe." Of course, the same sort of constitutionalist justification is unavailable in other contexts (e.g., GATT/WTO, NAFTA),

522. The notion of "slack" is taken from Michael E. Levine \& Jennifer L. Forrence, Regulatory Capture, Public Interests, and the Public Agenda: Toward a Synthesis, 6 J. Law, Econ. \& Organ. 167 (1990) (Special Issue). Levine and Forrence use agency and information theory to demonstrate the limits on political accountability of representatives and regulators due to the costs of information and monitoring (e.g., between voters and legislators, legislators and agencies, etc.). Levine and Forrence call this "slack." Id. at 174. 523. See supra note 68 and accompanying text.

524. Croley \& Jackson, supra note 4, at 209. 
where no pretense is made that the entity is anything other than an international organization of independent sovereigns. I would submit, however, that all such bodies share not merely a similar administrative character but also a propensity to deny that character through a kind of tacit constitutionalist logic. The challenge facing all supranational bodies is the same: how to balance the legitimate prerogatives of the organization's "sovereign" Member States against the broader interest of the membership as a whole "in realizing the gains of international coordination." ${ }^{525}$ In seeking this balance, however, there is a built-in preference-not unlike the ECJ's "preference for Europe"-to view realizing the gains of international coordination as decisively outweighing all other values, like democratic legitimacy. ${ }^{526}$ In the constitutionalist logic of supranational delegation, the abstract "membership at large" takes on the role of the legitimate political principal in the system, and it is to this abstraction that supranational agents are supposed to owe their loyalty. ${ }^{527}$ Legitimation is thus divorced from the representative institutions of each member and transferred to the supranational level-the membership at large. Once legitimacy is removed from the confines of the nation-state in this way-a process common to all instances of supranational delegation-it follows that any presumption in favor of particular members in disputes with the organization as a whole, even if justified on democratic legitimacy grounds, is "constitutionally" inappropriate. 528

525. Id. at 212.

526. Joerges and Neyer have gone so far to argue that "the legitimacy of governance within the constitutional [nation-]states is flawed in so far as it remains inevitably one-sided and parochial or selfish. ... The legitimacy of supranational institutions can be designed as a cure to these deficiencies-as a correction of 'nation-state failures' as it were." Joerges \& Neyer, supra note 55, at 292.

527. See, e.g., Croley \& Jackson, supra note 4, at 209.

528. According to Croley and Jackson, such deference "sinply has no analogne in the [supranational] context." Id. (criticizing the use of Cheoron deference in the GATT/WTO antidumping context). Joerges and Neyer atteinpt to justify supranationalism in deınocratic terms by arguing that the inevitable extraterritorial effects of national policies constitute, from the perspective of neighboring countries, soinething akin to "taxation without representation" - that is, a public burden that its citizens inust endure while remaining powerless to alter it through electoral ineans. See Joerges \& Neyer, supra note 55, at 292-93. Joerges and Neyer assert that "the very idea of democratic constitutionalism requires that constitutional states apply th[e] principle [prohibiting 'taxation without representation'] against themselves." Id. at 293. The notion of democratic constitutionalisin advanced by Joerges and Neyer thus requires "that the interests and concerns of non-nationals should be considered even within the national polity. In this sense, supranationalism does convey political rights and not just economic freedoms to Coinmunity citizens. Supranationalism is therefore to be understood as a fundamentally democratic concept." Id. (emphasis in original). This argument is normatively appealing but sociologically and historically problematic. It begs the question of the social, cultural and historical conditions that must exist before such political rights of non-nationals will be broadly and popularly interpreted as democratically legitimate. Conceptually, there may be a certain democratic dimension to arguments in favor of supranational governance, as Joerges and Neyer assert, but it is difficult to see how one can describe 
By regarding the membership at large as the relevant political principal in the system, however, the tacit constitutionalist logic of supranational delegation effectively ignores the issue of the democratic deficitthat is, the absence of a democratically-legitimate political principal capable of expressing or symbolizing the sovereignty of a self-governing people. This democratic symbolism is essential to lending public confidence to a political organization's normative functions. Regardless of the scale or constitutionalist pretense of an international regulatory organization, without this cultural foundation of democratic legitimacy, all we are left with, from the standpoint of popular perception, is a technocratic bodya supranational administrative agency-with an attenuated relationship to the perceived ultimate source of the agency's normative powers: the participating states severally as representatives of their "sovereign" peoples. The temptation to ignore this attenuated relationship, perhaps to read it out of the problem by arguing that the very idea of national sovereignty has become an anachronism, ${ }^{529}$ in my view simply lays the groundwork for serious, on-going democratic-legitimacy problems in supranational bodies.

As long as political identity clings to the nation-state-that is, as long as it lags behind the shift in the locus of normative power to the supranational level that has accompanied economic globalization-there will be democratic-legitimacy problems in supranational bodies. ${ }^{530}$ This is an empirical, sociological reality that cannot be theorized away. ${ }^{531}$ As one observer has warned, "focusing global issues on trade organizations does little to remedy the chronic 'democratic deficit' of international institutions." ${ }^{32}$ Rather, "the arrangements for global governance of economic interaction must command popular confidence," ${ }^{533}$ and yet, given the obstacles to democratically-legitimate political control at the supranational level, these arrangements are often found wanting in this critically important respect.

supranationalism as "fundamentally" democratic in the absence of the necessary sociohistorical underpinnings.

529. See, e.g., supra notes 83-84 and accompanying text.

530. However, Matláry, supra note 70, at 110, argues: "If [supranational decisionmakers] to an increasing extent defy classification as representing a given state, the inplications of this for the state as the source of legitimacy are that it is no longer the sole source of such legitimacy." Matláry sees this as the forerunner of "new political identities." Id. This characterization may be true, but for now there is a clear gap between the locus of normative power and the requisite common political identity needed to legitimate its exercise. See generally Deflem \& Pampel, supra note 61; Shore, supra note 61; Wood, supra note 61 .

531. The temptation to do precisely that, however, is strong, as if legitimacy tied to the nation-state were simply a question of "the choice and the basic definition of categories." Jachtenfuchs, supra note 14, at 129. "Sovereignty" is not simply an intellectual or conceptual category, but a cultural reality that gives meaning to social and political action.

532. Picciotto, Networks, supra note 18 , at $1055-56$.

533. $1 \mathrm{~d}$. 
There is, therefore, one clear and general lesson to draw from the European experience. Efficiency, measured in terms of realizing the gains from international coordination, cannot be divorced from other, less-quantifiable values like democratic legitimacy, without the threat of political backlash. ${ }^{534}$ Despite the federalist ideal that the Community's supranational institutions possess a kind of independent constitutional legitimacy, the pressures from below for some semblance of national political control have remained strong. Even as they have expanded the scope of qualified-majority voting in the Council, advocates of intensified European integration have had to accept a variety of substantive and procedural rules that are less than optimal when viewed from the standpoint of efficient international coordination-or, for that matter, of European "constitutionalism"-which, in some sense, amounts to the same thing. These include subsidiarity-not merely in Article 5 (ex art. 3b) of the Treaty but also the evidentiary requirements of the Subsidiarity Protocol attached to the Treaty of Amsterdam-the pillar structure, comitology, and variable geometry, along with the retention of unanimous voting in the Council in important domains. ${ }^{535}$ My proposed European Conflicts Tribunal would simply add to this list.

Although these rules might be difficult to comprehend on efficiency or constitutionalist grounds, they are entirely understandable when viewed from an administrative perspective. They are evidence of the profound cultural desire for democratically-legitimate political control over technocratic decisionmaking in the era of administrative governance, both national and supranational. Although a significant range of normative power has now been displaced to the European level, Community institutions have not become self-legitimating. Rather, their legitimacy continues to be channeled through the constitutional structures of the Member States, like any other administrative body. This is not to say that Community norms are inherently illegitimate, but only

534. On the concept of backlash, see generally Roe, supra note 80 . With specific relevance to the discussion of supranationalism rooted in free trade agreements, Roe writes: "Few economically-oriented analysts doubt the efficiency of free trade im most settings. But if free trade whips up a successful political backlash-the backlash thus far has failed to influence policy deeply - then efficiency analysis becomes harder." Id. at 238 n.40.

535. It should also be noted that in the aftermath of the Maastricht Treaty, in order to make the transfer of sovereignty acceptable, several countries introduced provisions into their constitution designed to increase domestic parliamentary monitoring of the Community's legislative output. See, e.g., Fr. Const. new art. 88-4 (requiring the Frencl1 Government to report proposed Community measures to the French Parliament if those measures would have fallen withm the domestic legislative domain); Grundgesetz art. 23 (requiring notice to the German Bundestag of Community legislation and an opportunity for the Bundestag to take a position); see also Treaty of Amsterdam, Protocol on the role of national parliaments in the European Union, preamble, 1997 O.J. (C 340) 113 (seeking "to encourage greater involvement of national parliaments in the activities of the European Union and to enhance their ability to express their views on matters which may be of particular interest to them."). 
that they are not worthy of the same degree of respect and deference owed to the output of a constitutional legislature on the national level.

Supranationalism is a phenomenon in search of a "mediating principle or principles"536 that will adequately account, on the one hand, for the legitimate needs of international coordination and, on the other, for the cultural persistence of the "sovereign" nation-state as "the primary political unit." 537 In my view, given the essentially administrative character of supranational bodies, administrative law is a good place to start looking for those principles, as the European example amply demonstrates. National specialists in administrative law must now join the broader scholarly debate over the proper means of legitimizing and controlling supranational normative power, not just in the Community but in other international organizations as well. Supranational delegation is never simply a question of choosing the best or most efficient institutional design ${ }^{538}$; rather, it inevitably raises concerns of democratic legitimacy that are central to the study of administrative law.

536. Croley \& Jackson, supra note 4, at 212.

537. Picciotto, Networks, supra note 18 , at 1055.

538. See Christian Joerges, Taking the Law Seriously: On Political Science and the Role of Law in the Process of European Integration, 2 Eur. L.J. 105, 107 (1996). For a view that emplrasizes efficient institutional design as the principal means to legitimation, see Majone, "Democratic Deficit," supra note 55, at 25. 